UNIVERSIDADE DE SÃO PAULO

FACULDADE DE FILOSOFIA, LETRAS E CIÊNCIAS HUMANAS

DEPARTAMENTO DE TEORIA LITERÁRIA E LITERATURA COMPARADA

PROGRAMA DE PÓS-GRADUAÇÃO EM TEORIA LITERÁRIA E LITERATURA COMPARADA

ANDRÉ TADAO KAMEDA

Rubem Braga nos anos 1950 e 1960:

integração nacional, modernização e autonomia da crônica

São Paulo

2018 
UNIVERSIDADE DE SÃO PAULO

FACULDADE DE FILOSOFIA, LETRAS E CIÊNCIAS HUMANAS

DEPARTAMENTO DE TEORIA LITERÁRIA E LITERATURA COMPARADA

PROGRAMA DE PÓS-GRADUAÇÃO EM TEORIA LITERÁRIA E LITERATURA COMPARADA

\section{Rubem Braga nos anos 1950 e 1960: \\ integração nacional, modernização e autonomia da crônica}

André Tadao Kameda

Dissertação apresentada ao Programa de Pós-Graduação do Departamento de Teoria Literária e Literatura Comparada da Faculdade de Filosofia, Letras e Ciências Humanas da Universidade de São Paulo, para a obtenção do título de mestre em Letras

Orientador: Prof. Dr. Edu Teruki Otsuka

São Paulo

2018 
Autorizo a reprodução e divulgação total ou parcial deste trabalho, por qualquer meio convencional ou eletrônico, para fins de estudo e pesquisa, desde que citada a fonte.

Catalogação na Publicação

Serviço de Biblioteca e Documentação

Faculdade de Filosofia, Letras e Ciências Humanas da Universidade de São Paulo

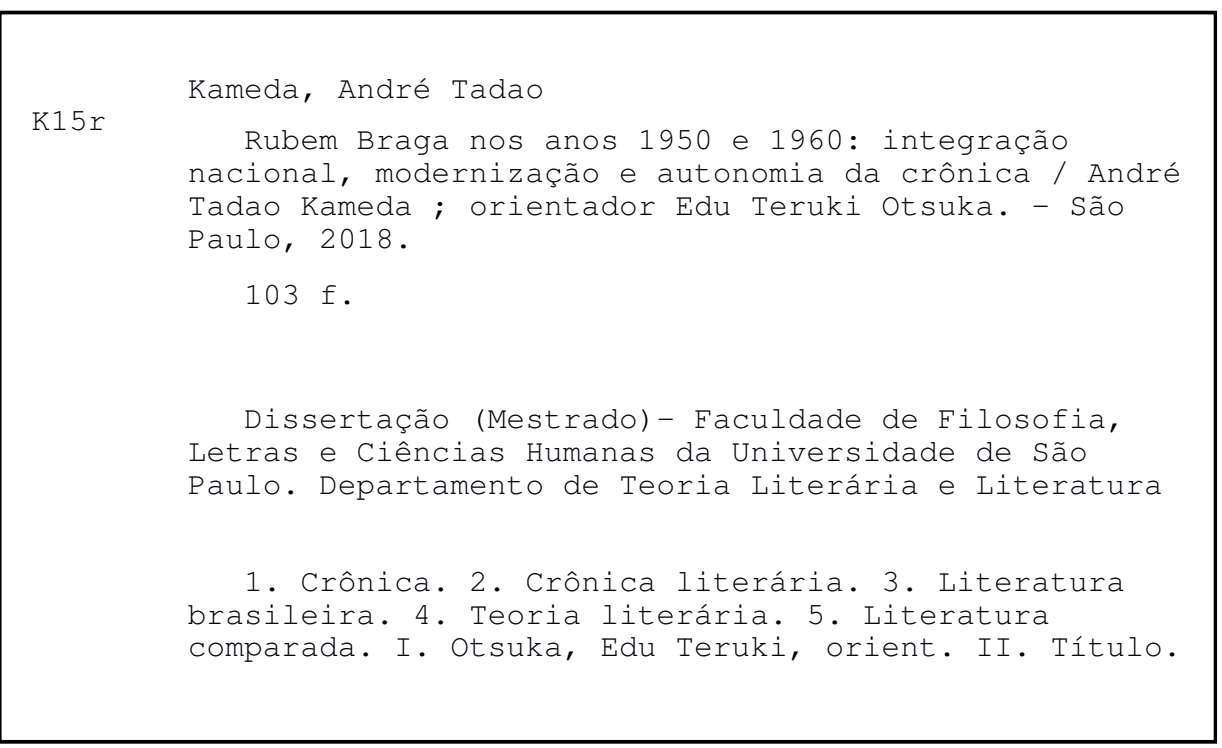


Nome: KAMEDA, André Tadao

Título: Rubem Braga nos anos 1950 e 1960: integração nacional, modernização e autonomia da crônica

Dissertação apresentada ao Programa de Pós-Graduação do Departamento de Teoria Literária e Literatura Comparada da Faculdade de Filosofia, Letras e Ciências Humanas da Universidade de São Paulo, para a obtenção do título de mestre em Letras

Aprovado em:

Banca Examinadora

Prof. Dr. Instituição:

Julgamento: Assinatura:

Prof. Dr. Instituição:

Julgamento: Assinatura:

Prof. Dr. Instituição:

Julgamento: Assinatura:

Prof. Dr. Instituição:

Julgamento: Assinatura: 
A meus pais,

Queico e Sumio,

começo de tudo. 


\section{Agradecimentos}

A Edu Teruki Otsuka, meu orientador, que acolheu este trabalho e acompanhou a sua elaboração, que sugeriu mudanças, apontou saídas e ajudou a melhorar o tom da dissertação. Agradeço a disponibilidade, a atenção e a paciência. As impropriedades ficam por minha conta.

Aos professores Augusto Massi e Ivan Francisco Marques, pela leitura minuciosa, pelas sugestões precisas e pelas indicações bibliográficas no exame de qualificação.

Aos professores Walter Garcia, Ana Paula Pacheco e lumna Maria Simon, que ministraram disciplinas na pós-graduação das quais pude fazer bom proveito.

À Luisa Destri, que ajudou muito a melhorar este trabalho.

Aos funcionários do Departamento de Teoria Literária e Literatura Comparada.

A meus pais, Queico e Sumio: sem vocês, nada disso teria sido possível; às minhas irmãs, Juliana e Renata, agradeço todo o apoio e carinho; ao Jun, afilhado e sobrinho querido, companheirinho para o que der e vier. À família Barros Tavares: Milkis, Paula, Felipe, Erich, Cláudia, Rafa, Helga, Lou e Raiane. A todos vocês, agradeço o suporte, o afeto e a compreensão nos momentos de ausência.

Aos amigos da Cásper (lá se vão 15 anos): Fernando, que leu uma primeira versão deste trabalho, Kelly, que me ajudou na reta final, Caio, Zé, Eugene, Ju, Kate, Luciana, Luisa, Milene e Mel (em memória). Um salve para os amigos de Osasco.

Aos amigos da GV, em especial Lucas, Ivo, Fabinho. Valeu pelos momentos de descontração!

À Ingrid, amor maior, que me ajudou com sugestões preciosas e vibrou junto com cada pequena descoberta, que me amparou nos momentos difíceis e suportou minhas oscilações de humor. Agradeço o carinho, a compreensão, a vida partilhada e o companheirismo de todas as horas. 
Comparada às grandes, a nossa literatura é pobre e fraca. Mas é ela, não outras, que nos exprime. Se não for amada, não revelará a sua mensagem; e se não a amarmos, ninguém o fará por nós. Se não lermos as obras que a compõem, ninguém as tomará do esquecimento, descaso ou incompreensão. Ninguém, além de nós, poderá dar vida a essas tentativas muitas vezes débeis, outras vezes fortes, sempre tocantes, em que os homens do passado, no fundo de uma terra inculta, em meio a uma aclimação penosa da cultura europeia, procuravam estilizar para nós, seus descendentes, os sentimentos que experimentavam, as observações que faziam - dos quais se formaram os nossos. ${ }^{1}$

Antonio Candido

${ }^{1}$ CANDIDO, Antonio. "Prefácio da 1a edição". In: Formação da literatura brasileira: momentos decisivos (1770-1880). $11^{\text {a }}$ ed. Rio de Janeiro: Ouro sobre Azul, 2007, p. 11. 


\section{Resumo}

O objetivo desta pesquisa é estudar a obra do escritor Rubem Braga e analisar a configuração da crônica moderna brasileira em conjunção com a perspectiva de integração nacional, horizonte que parecia alcançável no Brasil dos anos 1950. Para tanto, nos deteremos principalmente nos livros Ai de ti, Copacabana! (1960) e A traição das elegantes (1967), que compreendem a produção do cronista entre os anos de 1955 e 1967. Contudo, recorreremos quando necessário a crônicas anteriores a esse período, para ilustrar como o escritor veio forjando um estilo próprio, que por sua vez correspondia em alguma medida a mudanças políticas, sociais e culturais pelas quais o país passava desde 1930. Desse modo, pretendemos de início demonstrar tanto os fundamentos sociais e históricos do gênero quanto a filiação modernista da crônica de Braga. Em seguida, analisaremos em detalhe algumas crônicas representativas de sua produção, buscando identificar temas e formas recorrentes e sua relação com a arrancada modernizante daquela época. Depois, a intenção é verificar em textos de cronistas do período como a perspectiva de classe coloca problemas para a combinação de humor, poesia e fato miúdo, fórmula proposta por Antonio Candido para caracterizar a crônica moderna. Por fim, pretende-se mostrar como se dá a representação dos pobres a partir desse ponto de vista. A hipótese é que a crônica moderna, que teve em Braga um de seus grandes representantes, passa a lidar com impasses com o desmantelo da perspectiva de integração nacional, prometida pelo desenvolvimentismo daqueles anos e encerrada com o desfecho do golpe militar.

Palavras-chave: Rubem Braga; crônica moderna brasileira; Ai de ti, Copacabana!; $A$ traição das elegantes; forma literária e processo social. 


\begin{abstract}
This research aims to study the work of the writer Rubem Braga and to analyze the shaping of the Brazilian modern chronicle in the context of a national integration perspective, a horizon that seemed achievable in Brazil during the 1950s. In order to do so, we will focus mainly on the books Ai de ti, Copacabana! (1960) and A traição das elegantes (1967), which represent the writer's work between 1955 and 1967. When necessary, we will also resort to chronicles published prior to this period, to illustrate how the writer forged a style of his own, which, to a certain extent, corresponded to the political, social and cultural changes that the country had been undergoing since 1930. We intend, at first, to demonstrate both the social and historical foundations of this literary genre and the influence of the Brazilian Modernism in Braga's chronicles. Furthermore, we will analyze in detail some of his most representative chronicles, trying to identify recurrent themes and forms and their relation to the modernizing surge of that era. We will also investigate how the combination of humor, poetry and small fact, a formula proposed by Antonio Candido to characterize the Brazilian modern chronicle, can be problematic if analyzed through a social class perspective. Finally, based on this point of view, we intend to show the representation of poor people in different chronicles. The hypothesis is that the modern chronicle, which had in Braga one of its greatest representatives, starts to deal with impasses when the perspective of national integration, as promised by the developmentalism of that period, falls apart with the Brazilian military coup.
\end{abstract}

Keywords: Rubem Braga; Brazilian modern chronicle; Ai de ti, Copacabana!; A traição das elegantes; literary form and social process. 


\section{Sumário}

Introdução

1. Fundamentos sociais da crônica de Rubem Braga

1.1 Herança modernista

1.2 Fazendeiros do ar

1.3 Imprensa e história - integração nacional, indústria cultural e autonomia da crônica

2. Configuração lírica - temas e formas

2.1 A cidade e a roça

2. 2 A casa e a rua 57

2. 3. Memória e utopia

3. Uma questão de classe

3.1. Cronistas entre si

3.2. Figuras humildes

4. Sinais da mudança de uma fórmula

4.1. Problemas e impasses 
De leitura fácil e ligeira, a crônica moderna por longo tempo recebeu reduzida atenção da crítica especializada, embora tenha angariado grande sucesso de público. Por um lado, sua indefinição formal, no limiar entre o jornalismo e a literatura, dificultava a abordagem crítica; por outro, os estilos pessoais dos cronistas faziam com que cada um arregimentasse e ampliasse o seu próprio público leitor. Quando começou a se desenvolver no país, por volta de 1850, foi inicialmente chamada de folhetim (do francês feuilleton) e designava o espaço no jornal onde o escritor comentava os fatos do dia ou da semana. Ao longo do tempo, passou a ser chamada de crônica, perdeu a estrutura lógico-argumentativa e foi ganhando o ar de conversa, a leveza, o humor e o lirismo, aspectos que consolidaram o amadurecimento do gênero².

Tanto a sua classificação como gênero fronteiriço quanto o seu aspecto "frívolo" relegaram-na a um status de gênero menor. Mas, no mesmo passo em que a crítica a colocava em segundo plano, o público passava a consumi-la cada vez mais, justamente por seu estatuto apequenado: ao abordar assuntos banais do cotidiano com humor e lirismo, adotando um estilo coloquial e acessível, o cronista se aproximava do leitor, estimulando-o à convivência com as palavras.

Na década de 1930, quando a crônica começa a se consolidar, é possível observar em dois autores, Carlos Drummond de Andrade e Rubem Braga, a convergência de uma tradição clássica, por assim dizer, com a prosa modernista. "É como se (imaginemos) a linguagem seca e límpida de Manuel Bandeira, coloquial e corretíssima, se misturasse ao ritmo falado da de Mário de Andrade, com uma pitada do arcaísmo programado pelos mineiros." 3 Trata-se de uma fórmula característica de escritores de Minas Gerais, onde Braga viveu anos decisivos, e que beneficiou a geração posterior dos anos 1940 e 1950, como Fernando Sabino e Paulo Mendes Campos ${ }^{4}$.

Antonio Candido observou que a escrita das crônicas parece obrigar a uma "certa comunhão" e acaba produzindo um "ar de família" que une os escritores acima de suas particularidades ou diferenças. Para ele,

\footnotetext{
2 Parafraseio, neste e nos parágrafos seguintes, os argumentos de Antonio Candido em "A vida ao rés-do-chão", Recortes. 3르 ed. revista pelo autor, Rio de Janeiro: Ouro sobre Azul, 2004, p. 26-34.

3 lbid., p. 30.

${ }^{4}$ lbid., p. 30.
} 
(...) a crônica brasileira bem realizada participa de uma língua geral lírica, irônica, casual, ora precisa, ora vaga, amparada por um diálogo rápido e certeiro, ou por uma espécie de monólogo comunicativo ${ }^{5}$.

O crítico acrescenta que, nas crônicas, é possível perceber tanto essa comunidade quanto o estilo pessoal dos autores, dos quais apenas um foi "cronista puro, ou quase: Rubem Braga". Suas crônicas são objeto de dois importantes ensaios, de autoria de Davi Arrigucci Jr. Num deles, Arrigucci caracteriza o cronista como aquela espécie de narrador oral de que fala Walter Benjamin, anterior ao mundo capitalista, que incorpora os protótipos do marinheiro comerciante e do camponês sedentário, inserido entretanto no meio moderno do jornal. O crítico parte de uma visão benjaminiana do narrador para fixar a elaboração das crônicas no quadro da transição para a modernidade, em que a informação vem substituir a experiência, ou, em âmbito mais geral, no qual os meios de comunicação tomam o lugar das velhas narrativas.

Arrigucci admite que o seu estudo sobre Rubem Braga tem presente todo o tempo 0 ensaio de Benjamin ${ }^{6}$, embora ressaltando que cinquenta anos separam a publicação do alemão para a escrita de seu próprio ensaio ${ }^{7}$. Com isso, o crítico pretende diferenciar a situação tardia do capitalismo em países latino-americanos, nos quais, segundo ele, a tradição oral foi preservada na elaboração literária.

De fato, em meados do século passado as principais capitais do país vivem transformações rápidas e profundas. É nesse período que o Brasil se torna predominantemente urbano. Também nessa época, a imprensa passa por uma modernização técnica, principalmente nos jornais do Rio de Janeiro. Há um clima de otimismo no ar e o progresso econômico parece fornecer as condições materiais para a superação do atraso e a integração das regiões menos desenvolvidas do país. O lema do governo de Juscelino Kubitschek, "Cinquenta anos em cinco", dá a medida do salto superador almejado. A bossa-nova, que também servia de qualificativo para o presidente JK, deixava para trás os sambas-canção soturnos e sombrios e, na voz e no violão de João Gilberto, trazia uma "promessa de felicidade"8.

\footnotetext{
${ }^{5}$ Ibid., p. 34.

${ }^{6}$ ARRIGUCCI JR, Davi. "Braga de novo por aqui", Enigma e comentário. Ensaios sobre literatura e experiência, São Paulo, Companhia das Letras, 1987, p. 50.

7 Ibid., p. 49.

${ }^{8}$ MAMMì, Lorenzo. “João Gilberto e o Projeto Utópico da Bossa Nova”. Novos Estudos Cebrap, n. 34, São Paulo, Cebrap, nov. 1992, p. 70.
} 
Com efeito, naquela época o país parecia estar próximo de ver concretizada essa promessa. As interpretações que discutiam os processos de formação do Brasil, como as de Celso Furtado e Caio Prado Jr. - o primeiro no campo econômico, o outro no historiográfico -, pareciam apontar caminhos para a constituição de uma sociedade urbanoindustrial, enfim moderna e integrada.

É com essa matéria histórica que, acreditamos, Rubem Braga vai trabalhar. $\mathrm{O}$ narrador de suas crônicas é um sujeito que se desconcerta ante a velocidade das transformações que presencia. Segundo Arrigucci, é notável "a dificuldade desse narrador para generalizar a experiência pessoal, transformando-a em conselho prático para os outros, ao mesmo tempo que essa experiência em si mesma se vai tornando cada vez mais rala, num mundo que adotou o ritmo desnorteante das mudanças contínuas e imprevisíveis".

Com relação à história literária, a configuração de sua prosa também parece estar ligada a certa "tradição de auditório" que Antonio Candido identifica na literatura brasileira - a escrita concebida para um "público de auditores". O que se tem em vista, aí, é o caráter empenhado da tradição literária nacional, em que o público exigia uma combinação de "civismo", "nacionalismo" e "retórica" do homem de letras, que por sua vez incorporava essas exigências e acabava por desempenhar uma função cívica, além de ajudar a constituir uma identidade brasileira. Para fazê-lo, o escritor cunhava um estilo baseado na "facilidade" e na "ênfase" da fala, timbrando um "ritmo oratório" que passou a receber o selo de "boa literatura"10.

Essa "tradição de auditório", de escrita concebida para ser ouvida, permanece na crônica, mas desaparecem o aspecto monumental e opulento e vem à tona o "tom menor" e "familiar", para usar ainda uma vez as palavras de Candido11. Passa-se assim da oratória pública à conversa íntima, ambas ainda calcadas na oralidade.

Assim, embora procure travar um contato de tipo antigo, cordial, com seu leitor, já não se pode falar aqui em uma experiência coletiva, comunitarista, típica da vida no campo. O gesto do cronista pressupõe o isolamento moderno do indivíduo na cidade, e a aproximação que ele procura estabelecer com o leitor talvez deseje recuperar aquela antiga sociabilidade. Ao mesmo tempo, essa abordagem familiar e informal acendia no público

\footnotetext{
${ }^{9}$ ARRIGUCCI JR, Davi., "Braga de novo por aqui”, op. cit., p. 48.

${ }^{10}$ CANDIDO, Antonio. "O escritor e o público". Literatura e sociedade. São Paulo: Companhia Editora Nacional, p. $90-94$.

${ }^{11}$ Id., "A vida ao rés-do-chão", op. cit., p. 29.
} 
leitor, que crescia com a expansão dos meios de comunicação de massa, a imaginação de uma outra comunidade, em âmbito maior: a nação. Desse modo, o molde familista da relação cronista-público cria uma atmosfera favorável à perspectiva de integração nacional, que parecia perto de ser cumprida nos anos pré-1964.

Mas o ar de família entre cronista e leitor pode revelar outra faceta, qual seja, a dimensão "transitiva e civil"12 na exposição da crônica, como observou Arthur Vonk. Assim, embora reproduza uma relação de tipo cordial, pré-moderna, também vemos presente certo didatismo no trato com o leitor, revelador de uma perspectiva democratizante, na tentativa de chamá-lo para o aprendizado da sensibilidade. Esse movimento, no entanto, observa Vonk, desconsidera o desnível que permanece entre público e cronista, pois os volteios deste ainda concentram "a margem de capricho bastante para que a desigualdade se manifeste como dado da forma"13.

Assim, se os laços cordiais podem ser vistos com potencial para expandir uma dimensão democrática, também eles podem carregar em si a volubilidade dos que detêm a palavra. Talvez por esse motivo, Arrigucci veja

a necessidade de pensarmos nossos textos em seu contexto concreto, em toda a sua complexa particularidade, o que implica, na maioria dos casos, a necessidade de se compreender a natureza literária da forma mesclada e suas intrincadas relações com o processo histórico-social do desenvolvimento desigual ${ }^{14}$.

Com efeito, para uma compreensão mais profunda da crônica de Rubem Braga, talvez seja necessário relacioná-la com aquilo que Roberto Schwarz nomeou de matéria brasileira $^{15}$. Em breves palavras, trata-se do quadro peculiar de relações sociais no Brasil, cujos contornos começam a se definir no período da colonização, quando a economia baseada no latifúndio, na escravidão e no mercado externo produz três classes: o proprietário, o escravo e o homem livre dependente. Os últimos estavam sujeitos aos proprietários para ter acesso a bens e à vida social, por meio do favor, relação pela qual se reproduzia a classe dos dependentes. Visto que a relação produtiva de base era assegurada pela força, a vida ideológica nacional foi em grande medida regida pela prática

\footnotetext{
12 VONK, Arthur Vergueiro. Ao rés do chão sem chão: Drummond e a crônica moderna brasileira. Dissertação de mestrado FFLCH-USP, 2013, p. 62

${ }^{13}$ Com exceção da última ressalva, as observações se baseiam em "A vida ao rés-do-chão". CANDIDO, Antonio, op. cit., 2004.

${ }^{14}$ ARRIGUCCI JR., Davi, "Braga de novo por aqui", op. cit., p. 49.

15 Uma exposição detalhada pode ser encontrada em Roberto Schwarz, "Outra Capitu". Duas Meninas. São Paulo: Companhia das Letras, 1997, p. 91, e em outros livros do autor, indicados na bibliografia.
} 
do favor, que se tornou nossa "mediação quase universap"16 e assumiu diversos nomes, como o clientelismo, o patrimonialismo etc. Embora a escravidão tenha sido abolida posteriormente, o abandono dos escravos à sua própria sorte e o quase inexistente mercado de trabalho fez com que as relações sociais ficassem praticamente inalteradas.

Como se sabe, em diversos momentos decisivos da história do país, como a independência do país, a proclamação da República, além da abolição da escravatura, prevalece uma dinâmica em que os avanços só podem ser alcançados em função da permanência de aspectos atrasados do quadro social brasileiro. Nosso processo modernizante, portanto, "não se realiza apesar de um atraso em parte conservado, que seria preciso também ultrapassar, mas de uma modernização que se realiza pelo viés do atraso ou por meio de sua contínua reposição"17.

Por isso, uma segunda proposta deste trabalho é buscar delinear as feições da prosa de Rubem Braga e como elas podem estar relacionadas com essas dinâmicas sociais, próprias do país. Um atributo recorrente, por exemplo, dos escritos do cronista, salientado pela crítica desde muito cedo, é o de que se trata de uma prosa lírica. Com efeito, Arrigucci Jr. pede atenção para o leitor não se enganar com a sua "andadura de prosa", pois ele é "essencialmente lírico"18. Em definição parecida, foi celebrado como "poeta da crônica"19 e, porque exclusivamente cronista, foi considerado "poeta sem oficina montada" 20.

Especificando um pouco mais, já se disse que o seu lirismo é do tipo reflexivo, que consiste num "repensar constante pelas vias da emoção aliada à razão"21. Mais do que recursos técnicos para a composição poética, o que há de poesia em sua crônica estaria fundado numa "visão essencialmente lírica das coisas"22. Ou, dizendo de outro modo, sua prosa se decomporia "num ritmo poético", pois a poesia seria seu "estado natural de

\footnotetext{
${ }^{16}$ Sintetizo aqui alguns argumentos de Roberto Schwarz em "As ideias fora do lugar". In: Ao vencedor as batatas: forma literária e processo social nos inícios do romance brasileiro. 6ª ed., São Paulo: Duas Cidades, Ed. 34, 2012, p. 16. (Grifo do autor.)

17 PASTA JR, José Antonio; PENJON, Jacqueline. «Le rythme singulier d'une formation historique », Littérature et modernisation au Brésil. Paris: Presses Sorbonne Nouvelle, 2004, p. 10.

${ }^{18}$ ARRIGUCCI JR., Davi, “Onde andará o velho Braga?". Outros achados e perdidos. São Paulo: Companhia das Letras, 1999 , p. 149.

${ }^{19}$ REGO, José Lins do. "O poeta da crônica". In: FRANCHETTI, Paulo E. A.; PÉCORA, Antônio Alcir B. (Org.). Rubem Braga. São Paulo: Abril, 1980, p. 84-85.

${ }^{20}$ BANDEIRA, Manuel. "Velho Braga". In: FRANCHETTI, Paulo E. A.; PÉCORA, Antônio Alcir B. (Org.). Rubem Braga. São Paulo: Abril, 1980, p. 85.

${ }^{21}$ SÁ, Jorge de. A crônica. São Paulo, Ática, 1985, p. 13.

${ }^{22}$ PAES, José Paulo. "Rubem Braga" In: Pequeno dicionário crítico de Literatura Brasileira, 6aㅗ ed., São Paulo: Cultrix, 2001, p. 86.
} 
espírito"23. Houve ainda quem caracterizasse os escritos do "mais lírico" e "subjetivo dos cronistas brasileiros" como "poemas em prosa"24.

Nessa mesma linha, e procurando inseri-lo na tradição literária, Rubem Braga foi considerado "o mais poeta dos prosadores do Modernismo" e "o primeiro a elevar a crônica ao nível da mais alta categoria literária" 25 . Sua marca estaria na "supremacia da palavra sobre a frase", onde sua preferência pelas "minúcias e sutilezas" estaria mais ajustada aos "temas interiorizados" que também elege ${ }^{26}$. Esses temas, por sua vez, só poderiam ser captados por uma visão particular verdadeiramente poética e, para qualificar a sua prosa, seria necessário mobilizar um "vocabulário próprio da crítica de poesia"; se disposta em versos, sua prosa poderia mesmo passar por poema ${ }^{27}$.

Um de seus tradutores diz que o escritor é "antes de tudo um poeta, o menos acadêmico dos poetas", e chega a relacionar lirismo e nacionalidade: o cronista é "sulamericano, na verdade brasileiro, isto é, lírico por definição"28. A afirmação pode soar um tanto estranha, mas dá a ver a imagem do literato brasileiro aos olhos do estrangeiro: emotivo, nostálgico, afetivo; lírico, enfim.

No entanto, alguns estudos recentes revelam outras facetas do autor. Aquela que vai de encontro à do "coletor de epifanias"29 - a contraface do escritor lírico, digamos assim - é a do cronista engajado, crítico das questões de seu tempo e país. Trata-se de uma outra vertente de sua recepção crítica, que procurou destacar a verve mais combativa e política do autor.

Carlos de Jesus Ribeiro, por exemplo, pesquisou a lírica nas crônicas de Braga num primeiro estudo, em que relaciona temas recorrentes na obra do cronista, como a casa, a mulher, o mar $^{30}$. Numa pesquisa posterior, estudou crônicas em que estão presentes questões sociais, no intuito de desvencilhar Braga daquela primeira caracterização, como fica demonstrado no próprio subtítulo desse estudo: "a outra face do cronista lírico"31. No

\footnotetext{
${ }^{23}$ MILLIET, Sérgio. Diário crítico, vol. 2, São Paulo: Martins Editora, 1981, p. 300.

${ }^{24}$ COUTINHO, Afrânio. "Ensaio e crônica". A literatura no Brasil. São Paulo: Global, 2003, v.6, p. 133.

${ }^{25}$ CANDIDO, Antonio; CASTELLO, José Aderaldo. "Rubem Braga”, Presença da Literatura Brasileira, v. III, São Paulo: Difusão Europeia do Livro, 1964, p. 359.

26 PEREIRA, Lúcia Miguel. Correio da Manhã, Rio de Janeiro, 15 de jun. 1951. Caderno Cultura Brasileira, p. 11. Disponível em <http://memoria.bn.br/DocReader/089842 06/10039>. Acesso em 11 de março de 2018.

27 HOLANDA, Sérgio Buarque de. "Braga no País das Maravilhas". Folha da Manhã, São Paulo, 28 de nov. 1951. Disponível em <http://almanaque.folha.uol.com.br/sergiobuarque braga.htm>. Acesso em 11 de março de 2018.

${ }^{28}$ SIMON-BRÉSIL, Michel. "Avant-propos”. In: BRAGA, Rubem. Chroniques de Copacabana, de Paris et d'ailleurs. Paris:

Pierre Seghers, Éditeur, 1963, p. 8-9. Tradução livre de trecho do volume.

${ }^{29}$ ARRIGUCCI JR, Davi, "Braga de novo por aqui", p. 37.

${ }^{30}$ RIBEIRO, Carlos de Jesus. Caçador de ventos e melancolias: um Estudo da Lírica nas Crônicas de Rubem Braga.

Salvador: EDUFBA, 2001.

${ }^{31}$ Id., Rubem Braga: um escritor combativo - A outra face do cronista lírico. Rio de Janeiro, Booklink, 2013.
} 
entanto, Ribeiro não aprofunda a análise de texto das crônicas e apenas identifica se nelas estão presentes ou não as questões sociais.

Quem também se debruçou largamente sobre a crônica de Braga foi Ana Karla Dubiela, autora de dois livros sobre o escritor. No primeiro, ela estudou a formação da crônica de Braga, procurando desvendar tanto as influências (Manuel Bandeira, Jair Silva e o ambientalista Augusto Ruschi) quanto o contexto em que o escritor desenvolveu sua obra $^{32}$. Já no segundo, Dubiela busca aprofundar a face social do cronista, estudando duas crônicas do volume $A$ traição das elegantes e sua relação com posicionamentos políticos do autor, fatos biográficos e contexto histórico ${ }^{33}$. Mas, assim como em Ribeiro, a pesquisa não se detém no texto das crônicas, em sua estrutura, e apenas relaciona passagens com dados biográficos e o contexto histórico.

Já Anelize Vergara e Samantha dos Santos Gaspar abordam a atuação do cronista nas equipes dos jornais Diretrizes (1938-1939) e do semanário Comício (1952), respectivamente. Trata-se de publicações que combateram a ditadura do Estado Novo, no primeiro caso, e o segundo mandato de Getúlio Vargas, no segundo. No semanário Comício, Braga era responsável pela coluna "Os dias do presidido", paródia da coluna "Os dias do presidente", publicada no jornal varguista Última Hora. São estudos fundados sobretudo nas crônicas mais diretamente políticas, que tomam os escritos como documentos históricos, em que a análise da fatura do texto fica em segundo plano.

Arthur Vergueiro Vonk, em estudo sobre a crônica de Carlos Drummond de Andrade, analisa a contundente crítica social que Rubem Braga faz em "Os mortos de Manaus", constante do primeiro livro do autor, O conde e o passarinho (1936). Vonk analisa como no Rubem Braga da primeira hora se formaliza o vigor crítico do autor e como essa contundência inicial vai perdendo força ao longo do tempo, adquirindo a tranquilidade de “águas calmas" dos anos 1950, época áurea do gênero ${ }^{34}$.

Mais recentemente, em 2016, foi lançada uma caixa com três coletâneas inéditas de Rubem Braga ${ }^{35}$. São volumes que abrigam crônicas sobre artes plásticas, música e política. A empreitada parece ter sido levada a cabo justamente para revelar facetas menos

\footnotetext{
32 DUBIELA, Ana Karla. Um coração postiço - a formação da crônica de Rubem Braga. Fortaleza: Banco do Nordeste do Brasil, 2010.

${ }^{33}$ Id., A traição das elegantes pelos pobres homens ricos: uma leitura da crítica social em Rubem Braga. Vitória:

EdUFES, 2007.

${ }^{34}$ VONK, Arthur Vergueiro, op. cit., p. 125.

${ }^{35}$ BRAGA, Rubem. Os segredos todos de Djanira \& outras crônicas sobre arte e artistas. André Seffrin (org.), 1aㅡ. ed., Belo Horizonte: Autêntica Editora, 2016; _. Os moços cantam \& outras crônicas sobre música. Carlos Didier (org.), 1르. ed., Belo Horizonte: Autêntica Editora, 2016; e __. Bilhete a um candidato \& outras crônicas sobre política brasileira. Bernardo Buarque de Hollanda (org.), 1를 ed., Belo Horizonte: Autêntica Editora, 2016.
} 
conhecidas ou mesmo inesperadas do autor. Como se sabe, Braga era crítico diletante de artes plásticas (ele chegou a publicar um livro sobre três pintores primitivos brasileiros) e afirmava não ser apreciador de música (não tinha ouvido para canções, dizia). Suas crônicas que abordavam a política em sentido mais estrito, por talvez parecerem datadas, acabaram não saindo em livro até essa publicação.

Como se viu, num primeiro momento da recepção crítica do cronista celebrou-se o seu lirismo, sua capacidade de infundir poesia na prosa, a subjetividade extremada posta num relato objetivo. Já em momento posterior, buscou-se desfazer essa imagem, ou ao menos revelar outras facetas que não condiziam apenas com a de "poeta da crônica". Nesses estudos, procura-se destacar o envolvimento do escritor nas questões de seu tempo e país - como se sabe, Braga foi um ferrenho opositor de Getúlio Vargas desde 1930, atuou como correspondente de guerra, viu com desconfiança a instalação da ditadura militar para depois passar a ser crítico do regime, observou a transição do campo para a cidade no país. Essas pesquisas mais recentes procuram, em suma, reavivar a imagem do intelectual militante, que ele de fato foi, ainda que procurasse uma atuação independente, afastada da militância partidária.

Porém, essa divisão da recepção crítica entre a faceta lírica e a social de Rubem Braga talvez seja pouco produtiva para entender as ambivalências que cercam sua obra. Verdade seja dita que esses estudos mais recentes, que procuraram ressaltar os aspectos sociais de suas crônicas, também puderam identificar nelas algumas tintas líricas e outros traços recorrentes em sua obra, como o humor e a ironia. E nas crônicas mais líricas, mais subjetivas, em que rareia o dado factual? É possível encontrar nelas questões políticas, sociais e históricas?

Essa talvez seja uma tarefa complicada. Mas acreditamos que o decantado lirismo do cronista pode ter também um fundamento histórico-social. $\mathrm{O}$ ar de conversa, a nostalgia e a rememoração vão de par com a insolência, a frivolidade, a indiferença e a volubilidade. São formas que, a um só tempo, convivem e se contradizem, e podem remeter à própria maneira como se constitui a vida nacional.

O que se buscará aqui, portanto, será a abordagem crítica desses escritos, ou seja, a tentativa de encarar de maneira distanciada a proximidade tantas vezes solicitada pela crônica moderna. Com isso, pretendemos afastar a leitura empática e, ao mesmo tempo, manter a primazia do objeto, procurando ler nos termos articulados internamente em cada crônica o que pode levar para fora dela. Nesse sentido, analisaremos em detalhe as 
estratégias empreendidas pelo cronista e apontaremos possíveis nexos sociais que enformam e informam as crônicas, sem desgarrar demasiadamente do texto.

No primeiro capítulo, pretendemos discutir como a atitude lírica, que não se limita à poesia $^{36}$, está fundamentada numa dinâmica sócio-histórica própria do país. A intenção é verificar de que forma a obra de Rubem Braga se filia à "literatura da decadência rural", pontuando diferenças em relação a outros autores, como Cyro dos Anjos e Carlos Drummond de Andrade. Como notou Roberto Schwarz, sua figura central é o "fazendeiro do ar", verdadeira tradição das letras nacionais no século 20. O argumento será desenvolvido no cotejo com outros textos que abordam o assunto, como Intelectuais à brasileira, o livro de Sérgio Miceli que analisa a relação entre a classe dirigente e os intelectuais no país, e "A elegia de abril", na qual Mário de Andrade observa a construção do herói fracassado nos romances de seu tempo. A permanência dessa figura na década de 1950, descrita por Ivan Marques, também será observada. No detalhe, será verificada a modernização da imprensa e o nascimento de uma indústria cultural e, num aspecto mais geral, a urbanização carioca e a modernização do país.

No capítulo seguinte, pretendemos observar como essa atitude lírica se configura em crônicas dos livros Ai de ti, Copacabana e A traição das elegantes. Entendemos que o lirismo que serve de fundamento a esses textos vai ganhar variadas formas, como o ar de conversa, a atmosfera de sonho, a nostalgia e a rememoração, assim como abordar tópicas recorrentes, como a casa, a natureza, a infância e a mulher. Os movimentos desse narrador podem corresponder a formas sociais que se reproduzem na dinâmica de modernização do país, que promove o moderno por meio da reposição do arcaico.

Já no terceiro capítulo, por meio da análise de duas crônicas do livro $A$ traição das elegantes, pretende-se verificar a hipótese de que a fórmula moderna da crônica começa a lidar com impasses. Acreditamos que esses dois textos contenham indícios de uma transformação do gênero, tal como ele se configurou naqueles anos - com a junção do fato miúdo, do toque humorístico e da poesia, equação proposta por Antonio Candido. A mudança de registro pode ter fundamento no golpe de 1964, interrupção brusca de um impulso formativo que poderia vir a integrar o país - movimento no qual a crônica desempenhava também o seu papel.

\footnotetext{
${ }^{36}$ Anatol Rosenfeld explica que os termos lírico, épico e dramático podem se referir a traços estilísticos de que uma obra pode se imbuir, qualquer que seja o seu gênero. "Gêneros e traços estilísticos". O teatro épico, São Paulo: Perspectiva, 1985, p. 18-19.
} 
No quarto, a comparação com a produção de cronistas da mesma época terá por objetivo verificar problemas que possivelmente já se davam desde o surgimento da crônica moderna. O cotejo com outros escritores será interessante para observar o lugar social de onde eles produziam e a relação com pessoas de outras classes, notadamente os mais pobres.

Por fim, acreditamos que o estudo possa ajudar a compreender que a aparente facilidade da crônica não deve servir de desculpa para a crítica descartá-la de saída. Pelo contrário, a indagação sobre a configuração simpática da moderna crônica brasileira pode dar a ver a reprodução inconsciente de formas sociais - e que se reproduzem justamente por não nos darmos conta delas. 


\section{Fundamentos sociais da crônica de Rubem Braga}

\subsection{Herança modernista}

Numa crônica não publicada em livro, e republicada em diferentes épocas na imprensa ${ }^{37}$, Rubem Braga conta da influência que Manuel Bandeira exerceu sobre ele. A cada republicação, os títulos variam ("O que Manuel Bandeira me ensinou”, "Meu professor Bandeira" e "A lição de Manuel Bandeira"), mas a referência explícita ao poeta pernambucano e a alusão ao aprendizado permanecem em todas, dando a medida da importância dessa ascendência. Vale reproduzi-la abaixo na íntegra:

\section{Meu professor Bandeira}

Pela volta dos 15 anos, o poeta de quem eu mais gostava era mesmo Olavo Bilac. Lembro-me de ler seus versos sozinho no Campo de São Bento, em Niterói. Eu tivera de deixar o ginásio lá de Cachoeiro, no meio do $5^{\circ}$ ano, devido a um incidente com um professor. Vim terminá-lo no Salesiano de Santa Rosa, e morava na Rua Lopes Trovão, em Icaraí, na casa de uma família aparentada à minha, os Paraíso.

Não tinha amigos de minha idade: apenas companheiros de escola e outros de praia; com estes nadei muitas vezes de Icaraí até o fim da Praia das Flechas, passando por fora da Itapuca. Tinha até um sujeito que queria me levar para sócio atlético do clube Icaraí; naquele tempo havia a prova de travessia da Guanabara a nado, e ele fazia fé em mim; mas foi aí que veio uma sinusite gravíssima que me atrapalhou a vida.

Bem, mas não estou escrevendo para contar vantagem de nadador; falava de Bilac. Seu livro era como um amigo íntimo que fazia confissões e ouvia as minhas. Até hoje guardo uma terna lembrança de seus versos, e sempre me dói ouvir falar dele com pouco caso, como faz o Paulo Mendes Campos; acho um desaforo.

Pois logo depois de Bilac, o poeta que me empolgou foi Manuel Bandeira. Não sei como me caiu nas mãos "Libertinagem"; acho que foi meu irmão Newton quem me deu, em 1930 ou 1931. Logo depois arranjei "Poesias", que reunia os três livros anteriores do poeta. Minha adesão a Bandeira foi imediata e completa. Ele me ajudou não apenas a namorar minhas namoradas e a me conformar com o desprezo de outras, como a suportar rudes golpes afetivos que sofri, com a morte de pessoas queridas. Os versos de Bandeira passaram a fazer parte de minha vida íntima, ficaram ligados a momentos, pessoas, emoções; até hoje.

Lembro-me da surpresa e vaidade que senti, quando, um pouco mais tarde, fazia crônicas para um jornal de Belo Horizonte, e me contaram que várias pessoas pensavam que Rubem Braga era pseudônimo de Manuel Bandeira. É que na verdade sofri uma grande influência de Manuel; não de suas crônicas, pois estas eu não conhecia então, mas de seus poemas. A linguagem limpa e ao mesmo tempo familiar, às vezes popular, de muitos de seus poemas, influíram em minha modesta prosa. E da melhor maneira: no sentido da clareza, da simplicidade, e de uma espécie de franqueza tranquila de quem não se enfeita nem faz pose para aparecer

\footnotetext{
37 "Meu professor Bandeira" (Diário de Notícias, 23/9/67), "O que Manuel Bandeira me ensinou" (Revista Manchete, 30/4/66), "A lição de Manuel Bandeira" (Revista Nacional, 15 a 21 de maio de 1983). A crônica foi publicada em livro recentemente, com o primeiro título: BRAGA, Rubem. O poeta e outras crônicas de literatura e vida. Coordenação de André Seffrin. Seleção e prefácio de Gustavo Henrique Tuna. São Paulo: Global, 2017, p. 57-60. Sob o segundo título, a crônica foi publicada em 30/04/1966, na revista Manchete <http://docvirt.com/DocReader.net/AcervoRubemBraga/11578> e, sob o terceiro, na Revista Nacional, <http://docvirt.com/DocReader.net/AcervoRubemBraga/15494>. Acesso em 15 de fevereiro de 2018.
} 
diante do público. Acho que nenhum prosador teve influência maior em minha escrita do que o poeta Manuel.

Sim, muita coisa ele me ensinou. Só não me ensinou o milagre de sua condensação lírica e musical, o pulo de gato da poesia; mas também um escrevedor de jornal e revista não precisava saber tanto.

O que parece estar em jogo, nesta crônica, é a conexão entre experiência e literatura. Não só um fato decisivo da vida vai iniciar tanto poeta quanto cronista na vida literária, como também a própria obra de ambos será permeada de fatos biográficos. No caso de Manuel Bandeira, como se sabe, a evocação da infância, o cotidiano pobre da Lapa no Rio de Janeiro, sua vida solitária. Já Rubem Braga vai se recordar da infância em Cachoeiro de Itapemirim, de suas viagens, de seus relatos de guerra - abordagem ainda favorecida pelo próprio hibridismo da crônica, entre o relato factual e a ficção. Assim, para além de uma afinidade de formas, de linguagem, de estilo, a própria concepção que ambos têm da literatura é semelhante. Trata-se aqui de uma estética implicada por uma ética.

É possível observar ainda que certo penumbrismo de toque parnasiano-simbolista, presente ao longo da obra de Bandeira ${ }^{38}$, permanece na obra de Braga. Sem entrar em maiores detalhes por agora, essa continuidade que o cronista estabelece entre Bilac e Bandeira parece assinalar também a permanência, em sua crônica, de elementos de uma tradição literária anterior numa prosa dita moderna. Como em Bandeira, a passagem para a modernidade não se deu por ruptura, mas por continuidade. Na própria leitura da crônica, a passagem de Bilac a Bandeira não estabelece oposições: a transição é feita com naturalidade, sem adversativas nem ressalvas, sem hierarquia; eles são apenas colocados um em seguida do outro: Bilac é o primeiro, Bandeira é o segundo ${ }^{39}$. A caracterização dessa prosa que evita sopesar argumentos, ponderar outros pontos de vista ou estabelecer relações de causa e efeito já foi observada por Davi Arrigucci Jr. A sintaxe pouco

\footnotetext{
38 Essa continuidade foi observada por Norma Goldstein em Do penumbrismo ao modernismo: o primeiro Bandeira e outros poetas significativos. São Paulo: Ática, 1983. Segundo Wilson José Flores Jr., a autora vê uma evolução que iria de uma fase penumbrista até o momento em que o poeta conquista sua maior expressividade técnica, no Modernismo. Assim, para Flores Jr., Goldstein fala de modo algo inapropriado em "primeiro Bandeira", pois, para ele, "há recorrência intensa e permanente de certos procedimentos ao longo da obra do poeta pernambucano". Assim, em seu ponto de vista, seria inexato afirmar que Bandeira passa de uma fase a outra como se o modernismo fosse o seu auge. FLORES JR., Wilson José. Ambivalências em Pasárgada: a poesia de Manuel Bandeira em suas tensões. Tese de doutorado, UFRJ/ FL, 2013.

${ }^{39}$ Talvez soe exagerado exigir de uma crônica uma periodização literária. No entanto, a ausência de comparações e a equivalência que fica estabelecida entre os poetas são sintomáticas da concepção de literatura e da influência que os dois escritores exercerão sobre Braga. Com relação à sintaxe do trecho, veja-se esse comentário de Davi Arrigucci Jr.: "Desde o princípio, deve ter sido difícil dizer, com precisão crítica, o que eram aquelas crônicas. Pareciam esconder a complexidade pressentida sob límpida naturalidade. Disfarçavam a arte da escrita numa prosa divagadora de quem conversa sem rumo certo, distraído com o balanço da rede, passando o tempo, mais para se livrar do ócio ou do tédio, sem se preocupar com o jeito de falar. E, no entanto, uma prosa cheia de achados de linguagem, conseguida a custo, pelejando-se com as palavras: um vocabulário escolhido a dedo para o lugar exato; uma frase em geral curta, com preferência pela coordenação, sem temer, porém, curvas e enlaces dos períodos mais longos e complicados; uma sintaxe, enfim, leve e flexível, que tomava liberdades e cadências da língua coloquial, propiciando um ritmo de uma soltura sem par na literatura brasileira contemporânea" ("Braga de novo por aqui", op. cit., p. 30. Os grifos são nossos).
} 
estruturada parece desempenhar a função de evitar a valoração e afastar o conflito. Mais à frente, veremos outros exemplos desse tipo de construção.

O cronista se ressente e acha um desaforo quando ouve falar de Bilac com pouco caso, como o faz seu amigo Paulo Mendes Campos - também um cronista e um poeta moderno, aliás. Ou seja, não é que Bilac seja apenas algo de sua adolescência. No presente da crônica, embora não esteja explícito, Braga ainda parece gostar do poeta parnasiano. Vale notar também que o cronista se autodeprecia ao se referir a si mesmo como escrevedor de jornal e revista, de certo modo se justificando por não ter talento para a poesia. Ou seja, ele admira e sabe apontar as qualidades de um poeta, para afirmar no mesmo passo que alguém que escreve para a imprensa não necessita saber tanto quanto alguém que escreve poesia. O emprego do termo "escrevedor" ajuda a reforçar o sentido de modéstia diante do mestre, como se o cronista tivesse pudores em se atribuir o ofício de escritor.

Voltando ao argumento, a participação peculiar no Modernismo por Bandeira pode também nos dar pistas da singularidade de Rubem Braga. É interessante observar, por exemplo, a opinião de Braga sobre um dos livros fundamentais do Modernismo: Macunaíma, de Mário de Andrade. Em coluna publicada na Folha da Manhã em 1937, quando foi publicada a segunda edição da obra, ele chama a atenção para o fato de o livro ser "muito pouco lido" 40 . Para o cronista, o jeito de escrever de Mário seria "popular se não fosse precioso". Mais adiante, explica: "Reagindo contra a aristocracia do fraseado solene e a hierarquia difícil dos pronomes, ele caiu no populismo mais difícil e precioso." E pontua como gostaria que o livro fosse escrito:

(...) eu estimaria que alguém fizesse um livro com todo esse material precioso de Macunaíma, todo esse mundo de lendas e de falas brasileiras, de um jeito que fosse accessível ao leitor comum.

Parece evidente que a opinião de Braga diz bastante sobre o que ele próprio concebe como literatura. Para o cronista, apesar do rico material recolhido por Mário de Andrade no livro, seu estilo não é "acessível ao leitor comum". Ele afirma ainda que o escritor paulista pertence a um "pequeno clube fechado de gastrônomos" em São Paulo e que também faz gastronomia com a linguagem, enquanto "o paladar do povo é simples". Assim, a simplicidade e o caráter acessível que o cronista postula para os seus próprios escritos, e que ele encontra num poeta como Manuel Bandeira, por exemplo, são aspectos que ele gostaria de ver presentes em uma obra emblemática para o Modernismo como Macunaíma.

\footnotetext{
40 BRAGA, Rubem. "Os defeitos de Macunaíma". Folha da Manhã. São Paulo, 4 de maio de 1937. Disponível em: <http://almanaque.folha.uol.com.br/semana5.htm>. Acesso em 12 de junho de 2018. Devo a indicação a Ivan Marques.
} 
Nesse sentido, é interessante notar a crescente divergência na concepção de poesia entre Mário e Bandeira, ao longo da duradoura correspondência trocada entre ambos. Marcia Regina Jaschke Machado chama a atenção para cartas trocadas em 192941, nas quais Bandeira comenta a série "Poemas da negra", que Mário de Andrade publicaria no ano seguinte no volume Remate de Males. Na missiva, o poeta pernambucano diz não ter sentido nada com a leitura, pois os poemas não Ihe suscitaram "emoção artística". "Não posso dizer que não gosto, ou que não gosto disto ou daquilo", confessava Bandeira.

Em resposta, Mário de Andrade tenta explicitar os motivos da discordância. “(...) é nisso que estamos atualmente no máximo de separação: você todo sensibilidade, todo impulsivo, eu cada vez mais recatado, mais artífice, mais principalmente invisível." Os termos do escritor paulista são reveladores das concepções cada vez mais distantes da poesia que cada um produzia. Enquanto Mário se afasta do psicologismo da primeira fase, colocando mais ênfase agora na técnica, Bandeira permanece com a visão espontânea e subjetivista do fazer poético. É à concepção bandeiriana de lirismo que Braga vai se ligar.

São valores que parecem se confirmar em outra crônica, "O mistério da poesia"42, na qual Braga divaga sobre os primeiros versos de um poema que lhe ficaram na cabeça: "Trabajar era bueno en El Sur. Cortar los árboles, hacer canoas de los troncos." ${ }^{43}$

O cronista faz uma espécie de análise literária dos versos e observa a disposição das palavras, o tempo dos verbos, os termos utilizados. Ele repara que são palavras "das mais banais da língua" e que tudo está dito com "os elementos mais simples". E relembra um verso de Camões, "A grande dor das coisas que passaram", no qual o que o impressiona é essa "faculdade de dar um sentido solene e alto às palavras de todo dia".

O cronista cogita que talvez sua emoção venha da simplicidade rústica da canoa, com sua "grande beleza plástica", e fazendo-o recordar de sua "infância de beira-rio e beiramar". Mas há também o sentido do trabalho, que ele considera como principal: o "desejo de fazer uma coisa simples, honrada e bela", e não a "necessidade aborrecida" de hoje.

Braga conclui que muitos escritores modernos procuram o mistério poético enunciando "coisas obscuras", o que não quer dizer que, "turvando um pouco as águas,

\footnotetext{
${ }^{41}$ MACHADO, Marcia Regina Jaschke. "Lirismo no debate epistolar modernista". O eixo e a roda, v. 23, nำ, 2014, p. 1536.

${ }^{42}$ BRAGA, Rubem. "O mistério da poesia". A Traição das Elegantes. Rio de Janeiro: Ed. Sabiá, op. cit., p. 7-9.

${ }^{43}$ Id., "O mistério da poesia", op. cit., p. 7. (Grifo do autor.) Trata-se dos versos iniciais de Rapsodia de Saulo, de Aurelio Arturo, um poeta colombiano - e não boliviano, como pensa o cronista. Ver ARTURO, Aurelio. "Rapsodia de Saulo". Morada al Sur. Bogotá: Universidad Externado de Colombia, 2004, p. 57-60. Disponível em <https://www.uexternado.edu.com/wp-content/uploads/2017/01/7-moradaAISur-AurelioArturo.pdf>. Acesso em 19/07/2018.
} 
elas fiquem mais profundas...". Aqui, ele parece contrapor a certa concepção de poesia moderna, que tem na obscuridade seu elemento central ${ }^{44}$, aquele princípio de clareza e simplicidade que postula como uma espécie de poética de suas crônicas. Em pauta está também o trabalho artesanal e paciente, realizado na paisagem natural, ao contrário do trabalho alienado da rotina citadina, cujo sentido não se alcança e acaba sendo apenas uma obrigação tediosa.

De seu lado, Manuel Bandeira também encontrava afinidades com Rubem Braga. Em crônica na qual saudava os 50 anos do amigo, Bandeira destaca que o segredo dele era "pôr nas crônicas o melhor da poesia que Deus lhe deu". O poeta ressalva que outros também o fazem, mas que guardam a melhor parte para seus poemas. Por isso, chama-o de "poeta sem oficina montada". O pernambucano acrescenta ainda que, parecendo distraído, o cronista está na verdade atento a tudo e "anota nos escaninhos do subconsciente os mil detalhes da vida enorme", que cedo ou tarde vão aparecer nas crônicas, convocados pela memória de Braga, para surpreender a sensibilidade incauta do leitor.

Essa atitude do cronista, distraído mas atento, é a mesma de que o poeta procura dispor diante da vida. Davi Arrigucci Jr., ao analisar o "Poema tirado de uma notícia de jornal", no estudo talvez mais aprofundado sobre a obra do escritor pernambucano, chama a atenção para uma crônica em que Bandeira considera o poeta como "um sujeito que sabe desentranhar a poesia que há escondida nas coisas, nas palavras, nos gritos, nos sonhos" e que, por isso, deve sempre estar "atento a essa poesia errante". Para tanto, o poeta deve exercitar uma "apaixonada escuta" para os "raros momentos" em que possa desentranhar a poesia do mundo 45 .

É, portanto, pela via bandeiriana que Braga vai se ligar aos valores caros ao primeiro modernismo. O coloquialismo, a informalidade e a adesão ao cotidiano da vida popular vão substituir o beletrismo, a impostação e a atmosfera metafísica/espiritual da tradição literária anterior. Segundo Arrigucci, essas mudanças implicavam "uma abertura maior da vida do espírito para a realidade presente de um país largamente desconhecido de si mesmo e para a novidade de fatos palpáveis da existência material de todo dia".

\footnotetext{
${ }^{44}$ Cf. BERARDINELLI, Alfonso. "Quatro tipos de obscuridade". Da poesia à prosa. São Paulo: Cosac Naify, 2007, p. 134142. O crítico italiano refuta a centralidade que Hugo Friedrich, em seu Estrutura da lírica moderna, reputa à poesia de Mallarmé para a modernidade na poesia.

${ }^{45}$ ARRIGUCCI JR., Davi. Humildade, paixão e morte: a poesia de Manuel Bandeira. São Paulo: Companhia das Letras, 1990, p. 92.
} 
Ainda nas palavras do crítico, tais transformações se dão principalmente a partir da década de 1930, acompanhando as mudanças drásticas por que passa o país na época e que vão reverberar na própria vida cotidiana. De acordo com Arrigucci, a partir de Libertinagem, de 1930, "a vida de relação, tal como se mostrava no dia a dia, se torna matéria literária"46.

Do mesmo modo, a atitude humilde assumida tanto pelo poeta quanto pelo cronista por certo tem relação com a aproximação aos pobres, às "formas simples de vida" do cotidiano das camadas mais baixas da população. Ao assumir essa posição, ambos parecem desejar tomar a mesma perspectiva dos de baixo, numa relação de solidariedade que procura ver pelos olhos do seu outro de classe. Ainda assim, por mais que haja uma real preocupação com os desvalidos, alcança-se no máximo falar sobre eles, e não a partir de sua perspectiva. Em outras palavras, as barreiras que os separam não podem ser transpostas apenas pela linguagem, ou pela proximidade que esses escritores eventualmente tivessem com os pobres.

Arrigucci também compara a visão instantânea do cronista com o alumbramento de Bandeira. Em ambos, afirma, esses momentos de iluminação são trazidos invariavelmente para o chão humilde do cotidiano, por estarem intimamente ligados à base material do corpo, a um certo sensorialismo em que poético e erótico se fundem. Todavia, esse materialismo, ligado à atitude humilde, compreende também "algum componente cristão", do mesmo modo que, em Bandeira, pode-se observar um "franciscanismo essencial".

Arrigucci nota que escritores modernistas buscaram essa proximidade com os pobres e relata a impossibilidade, evidente, de assumir sua perspectiva. Mas essa aproximação, observa, tinha o mérito de ao menos buscar uma visão mais adequada da realidade do país, longe da versão oficialista das classes dominantes. Por vezes, essa tendência era facilitada pela "experiência pessoal trabalhada esteticamente", como era o caso de Bandeira. Segundo o crítico, a observação do cotidiano popular no morro do Curvelo e na Lapa, nos anos 1920 e 1930, quando morou num "quarto pobre de doente recolhido e solitário", assim como a pobreza com que toma contato na infância passada no Recife, tornam a sensibilidade do poeta receptiva à vida das classes mais baixas ${ }^{47}$.

No caso de Braga, a percepção do cotidiano popular, além da influência de Bandeira, foi favorecida, segundo o crítico, pela "experiência mais socializada" da formação distante

\footnotetext{
${ }^{46}$ Ibid., p. 53. Grifos do autor.

${ }^{47}$ ARRIGUCCI JR., "Braga de novo por aqui", op. cit., p. 40.
} 
dos centros urbanos, "à beira-rio ou à beira-mar", e também "pela proximidade das pessoas humildes" e a convivência com "formas do trabalho manual"48.

Enfatize-se aqui o uso recorrente do termo experiência. Desde a leitura da crônica em que Braga homenageia Bandeira, pudemos ver como a experiência pessoal tem peso decisivo na obra de ambos, para além da declarada influência mútua de cronista e poeta. Assim, um acontecimento decisivo como uma doença faz ambos se voltarem para a literatura, e eles a concebem segundo critérios parecidos. A evocação da infância no âmbito rural (ou provinciano), a aproximação aos mais pobres e a linguagem limpa, clara e familiar são aspectos presentes na obra de ambos.

Essa noção de experiência, Arrigucci por certo a toma emprestada de Walter Benjamin. Segundo o crítico alemão, ela está ligada à sabedoria, à arte de narrar, a qual ele previa em vias de desaparecer. Com o desenvolvimento técnico do capitalismo, as narrativas que transmitem os saberes de geração em geração vão se tornando raras e são substituídas pelo romance e, mais tarde, pela informação do jornal ${ }^{49}$. Por meio dessa sociabilidade mais antiga, vivenciada por ambos - Bandeira em bairros populares de Recife e do Rio de Janeiro, Braga na vida de província e no meio rural de Cachoeiro do Itapemirim -, Arrigucci vê que poeta e cronista ainda disporiam dessa experiência acumulada e teriam preservado a capacidade para contar.

Essa caracterização de um mundo pré-moderno sinaliza a permanência de um universo em vias de acabar, o rural, em um contexto urbano que começa a ganhar preeminência. $O$ que equivale a dizer que o velho mundo rural permaneceu, ainda por algum tempo, na cidade. É nesse universo que surge uma figura bastante presente na tradição literária nacional: o fazendeiro do ar.

\subsection{Fazendeiros do ar}

Em "Fim de Semana na Fazenda" 50 , o cronista nos conta sobre um passeio em uma antiga fazenda cafeeira na região do Rio Preto e do Rio Paraibuna, interior do Estado do

\footnotetext{
48 lbid., p. 41.

${ }^{49}$ BENJAMIN, Walter. "O Narrador. Considerações sobre a obra de Nikolai Leskov", Magia e técnica, arte e política. São Paulo: Brasiliense, 1994, p. 197-221.

${ }^{50}$ BRAGA, Rubem. Ai de ti, Copacabana! Rio de Janeiro, Editora do Autor, 1960, p. 59-63.
} 
Rio de Janeiro. Lá, o narrador divaga sobre os retratos de um casal, antigos moradores e donos do lugar. Ao longo da crônica, alterna-se o elemento social com o dado da natureza. Vejamos como essas questões se desdobram na crônica:

\section{Fim de semana na fazenda}

São fazendas dos fins do século passado, não mais. Seus donos ainda estão lá; já não se balançam, é verdade, nas cadeiras austríacas da varanda; nem ouvem a partida desse bando de maritacas que se muda para o morro do outro lado da várzea.

Ou talvez ouçam, quem sabe. Mas estão hirtos dentro de suas molduras, nas paredes da sala. Assim, rígidos, pintados a óleo, eles parecem reprovar nossos uísques e nossas conversas. Mas eis que Mário Cabral toca o Corta-Jaca no velho piano de cauda, e creio que eles gostam, talvez achem uma interessante novidade musical vinda da Corte. Mário ataca uma velha música francesa - Solitude - e creio bem que vi, ou senti, a senhora viscondessa suspirar de leve.

Ah, senhora viscondessa! Que solidão irremediável não sentis dentro de vossas grossas molduras douradas. Olhais para a frente, dura, firme. Lá fora as mangueiras e jabuticabeiras estão floridas, na pompa da manhã. Um beija-flor azul corta o retângulo da janela no seu voo elétrico e se imobiliza no ar, zunindo; insetos zumbem; a menina da casa passa no cavalo em pelo, a galope. Onde está vosso belo silhão? Onde está o senhor visconde?

Ele está em outra parede, também duro, de uniforme e espada, e seu casaco militar tem um pendão de penas de tucano. Não olha a esposa. Os dois não se olham. Alguma intriga? Não. Apenas eles estão cansados de estar casados, cansados de estar mortos, cansados de estar pintados, cansados de estar emoldurados e pendurados - e tão cansados e enfadados que há mais de sessenta anos não chupam uma só jabuticaba, sequer.

Se eu dissesse que cantava, mentiria. Não cantava. Estava quieto; demorou-se algum tempo, depois partiu.

Mas eu presto meu depoimento perante a História. Eu vi. Era um sabiá, e pousou no alto da palmeira. "Minha terra tem palmeiras onde canta o sabiá." Não cantou. Ouviu o canto de outro sabiá que cantava longe, e partiu.

Era um sabiá-laranjeira, de peito cor de ferrugem; pousou numa palmeira cheia de cachos de coquinhos, perto da varanda. Ouviu um canto distante, que vinha talvez dos pés de mulungu. Sabeis, naturalmente: é agosto e os mulungus estão floridos, estão em pura flor, cada um é uma grande chama cor de tijolo. Foi de lá que veio um canto saudoso, e meu sabiá-laranjeira partiu.

Mas ele estava pousado na palmeira. Descansa em paz nas ondas do mar, meu velho Antônio Gonçalves Dias; dorme no seio azul de lemanjá, Antônio. Ainda há sabiás nas palmeiras, ainda há esperança no Brasil.

Vamos pela estrada, e de vez em quando divisamos a sede de uma fazenda. Esses fazendeiros das margens do Rio Preto e do Paraibuna eram todos barões, pelo menos. E tanto mais fidalgos quanto maiores suas senzalas e seus terreiros de café. Diante das casas plantavam palmeiras imperiais.

As enxurradas arrastaram o húmus de seus cafezais, abriram voçorocas; os negros libertos viraram erosão social e as casas imensas ficaram malassombradas. Restaram os morros de pasto, hoje pintalgados de vacas holandesas. Dentro das capoeiras altas os pés de café velho se escondem, como árvores nativas; viraram mato. Agora, de vez em quando, um bisneto derruba o mato, planta café novo, com mão de obra cara e difícil. Revejo com alegria essa eterna paisagem de minha infância, os morros penteados de cafezais, entre rios tortos. Mas as novas gerações não aprenderam nada e não esqueceram nada. Os cafeeiros continuam a ser plantados morro acima, sem obedecer à curva de nível, sem nenhuma defesa 
contra as águas precípites dos temporais estrondosos de verão. O penoso trabalho de meio século da natureza vai ser outra vez desperdiçado; voltamos a plantar decadência.

Ah, no lugar de palmeiras imperiais refaçam suas aleias com palmeiras finas e líricas de palmitos. Assim pelo menos os seus netos cortarão as palmeiras e comerão os palmitos, antes de partir definitivamente para um emprego em qualquer iapeteque ${ }^{51}$.

Mas ainda há cercas vivas de bambu, no lombo dos morros. Ainda há céu; ainda acontecem nuvens de leite nas amplas tardes morenas. E os rios, talvez mais magros, continuam a rolar entre pedras sob os ramos pensativos das ingazeiras pardas e verdes. E nos beirais continua a haver andorinhas.

Passo a tarde à toa, à toa como o poeta, vendo andorinhas. Amo seu azul metálico, a elegância aguda de suas asas em voo, seu chalrear álacre dos mergulhos enviesados, quando caçam insetos. Onde vivia a andorinha, no tempo que não havia casas? Ela é amiga da casa do homem. Arquiteto, meu amigo arquiteto, nenhuma casa é funcional se não tiver lugar para a andorinha fazer seu ninho.

Mas é na casa da fazenda que a andorinha está à vontade. Melhor do que nessas casas imensas dos coronéis e dos velhos barões, elas só se dão mesmo nas grandes casas de Deus, as velhas igrejas escuras e úmidas que elas povoam de vida e de inquietação. Nenhuma outra ave do céu é mais católica.

É noite na fazenda; e a lua nasce, atrás do morro. Fico sozinho na varanda assistindo com uma vaga, irracional emoção, a esse antigo mistério. Luar, amar...

Seria preciso amar alguém, talvez aquela sinhá tão moça e tão antiga, cujo retrato está no salão de jogos. A mesma que aparece com seus quarenta e cinco anos, ainda bela, no quadro ao lado. Essa já viveu na República. Ouvi contar suas histórias. Era mesmo linda, e foi feliz; o marido a adorava.

Ah, se eu fosse daquele tempo ela não seria minha, a bela sinhá. Ela seria a moça fazendeira e eu seria um colono pobre e feio, sempre meio barbudo e calado.

Penso de repente essa coisa triste, triste, e deixo a varanda, abandono a lua, regresso ao governo Kubitschek.

Estado do Rio, setembro, 1957.

Organizada em cinco blocos, a crônica descreve um passeio de fim de semana do narrador a uma fazenda do interior do Estado do Rio de Janeiro ${ }^{52}$. Na primeira parte, a menção a cadeiras austríacas, a um velho piano de cauda, aos títulos nobres de viscondessa e visconde, ao silhão usado pela dona, à espada do dono e ao seu casaco militar com pendão de penas de tucano dão indícios de um passado faustoso e aristocrático.

\footnotetext{
51 Trata-se do extinto Instituto de Aposentadorias e Pensões dos Empregados em Transportes de Cargas (lapetec), incorporado em 1966 com a criação do Instituto Nacional de Previdência Social, que unificou os institutos de aposentadorias e pensões de diversas categorias de trabalhadores. Disponível em: <http://www.fgv.br/cpdoc/acervo/dicionarios/verbete-tematico/instituto-nacional-de-previdencia-social-inps>. Acesso em 11 de março de 2018. O cronista parece utilizar a expressão em sentido metonímico, para se referir a uma repartição burocrática qualquer.

52 É possível inferir que se trata do Vale do Paraíba, região estudada por Maria Sylvia de Carvalho Franco em Homens livres na ordem escravocrata, 4aㅡ ed., São Paulo: Fundação Editora da Unesp, 1997. Embora a autora concentre seu estudo na cidade de Guaratinguetá, a região como um todo (mas não só ela; como se sabe, a economia do país girou em torno do café por um longo período) sofreu as consequências da decadência do plantio do café. Mais à frente, como se verá, o cronista menciona especificamente as plantações cafeeiras e atribui as razões para o encerramento do ciclo do café.
} 
Em contraposição à dureza, à rigidez dos retratos dos proprietários, o cronista marca a agilidade da natureza, com pássaros voando, árvores florescendo, insetos zunindo. Outra contraposição a essa rigidez é a espontaneidade do presente da crônica, simbolizada nos próprios visitantes ${ }^{53}$, que tocam música ${ }^{54}$ e bebem uísque.

No segundo bloco da crônica, o cronista avista um sabiá que traz à sua lembrança os versos iniciais da "Canção do Exílio", de Gonçalves Dias. No entanto, ao contrário do poema romântico, o passarinho não canta, embora também esteja numa palmeira e comova o narrador. O fato de ainda haver sabiás nas palmeiras é relacionado com a esperança no país ${ }^{55}$. Nos três primeiros parágrafos desse trecho, o cronista parece fazer uma caracterização gradativa do sabiá: no primeiro, ele afirma ter visto algo mas não revela que se trata de um sabiá, diz apenas que estava quieto e partiu; já no segundo, ele diz que era um sabiá numa palmeira, que parte depois de ouvir o canto de outro pássaro; no terceiro, por fim, ele dá as características físicas do sabiá e descreve uma outra árvore, de onde talvez tenha partido o canto do outro pássaro. Esses três parágrafos são variações de um mesmo acontecimento, pois terminam com a partida do sabiá depois de ouvir o canto. A

\footnotetext{
${ }^{53}$ Rubem Braga traça o perfil do pianista Mário Cabral em outra crônica. Segundo afirma, o músico acompanhou nos anos 1930 os principais artistas no rádio. Foi também advogado de vários escritores, como Vinícius de Morais, Paulo Mendes Campos e Lúcio Rangel. A certa altura, Braga escreve: "É o mais atento e delicado dos amigos e bebe seu uísque com moderação, porém constância". O cronista conta que Cabral ganhou o epíteto de "saudoso" quando certa vez Orlando Silva assim o apresentou num espetáculo. BRAGA, Rubem. "Mário Cabral, o saudoso". Os moços cantam \& outras crônicas sobre música. Carlos Didier (org.), 1a ed., Belo Horizonte: Autêntica Editora, 2016, p. 136-138.

${ }^{54}$ A música conhecida como "Corta-Jaca", cujo título é na verdade "Gaúcho", é um tango composto por Chiquinha Gonzaga que provocou escândalo em 1914, quando foi tocada pela então primeira-dama, Nair de Teffé, numa recepção no Palácio do Governo. Como não se tocava música popular nesse tipo de ocasião, o episódio causou polêmica e provocou reações da elite carioca, uma das quais foi um discurso de repúdio do então senador Rui Barbosa. A certa altura, a letra diz: "Esta dança é buliçosa/ Tão dengosa/ Que todos querem dançar/Não há ricas baronesas/ Nem marquesas/ Que não saibam requebrar, requebrar". Na crônica, a referência à canção remete a um passado talvez contemporâneo dos donos da fazenda, mas que reforça a espontaneidade do presente em oposição à rigidez do passado. A canção também parece ser representativa de um mundo aristocrático em decadência e a emergência de um universo moderno e urbano ("CORTA-jaca" no Catete: centenário da alforria da música popular. Chiquinha Gonzaga. 2014. Disponível em: <chiquinhagonzaga.com/wp/corta-jaca-no-catete-centenario-da-alforria-da-musica-popular-brasileira/>. Acesso em 18 de fevereiro de 2018).

${ }^{55}$ Veja-se, a título de comparação, uma outra releitura do poema de Gonçalves Dias, a canção "Sabiá" (1968), de Tom Jobim e Chico Buarque. Lorenzo Mammì observa que, na primeira estrofe, embora o sujeito lírico afirme que vá voltar, a melodia sugere o distanciamento da terra natal. Na estrofe seguinte, já não há palmeiras, as flores já não brotam, as noites indesejadas estão bem presentes. O sujeito da canção se arrepende então de ter se enganado com seus próprios planos, de não ter se encontrado, de ter se perdido nos caminhos que trilhou. A conclusão de Mammì é de que, em verdade, "não há volta". O crítico conta ainda que Tom Jobim escreveu à revelia de Chico Buarque uma estrofe adicional, excluída depois nas gravações, em que podemos ver a tentativa de recuperar a "promessa de felicidade" da bossa nova: "Sei que o amor existe e não sou mais triste/E que a nova vida já vai chegar/E a solidão vai se acabar". Mammì também relata que muitos viram na música um pressentimento de Chico Buarque de sua saída do país, buscando incutir nela um sentido político, mas o crítico observa que a canção não trata propriamente de exílio, e sim de alienação. De acordo com ele, "A ilusão de uma modernização doce, segundo a qual uma industrialização acelerada poderia conviver com o clima edênico da beira-mar carioca, se desfaz definitivamente nessa canção. Talvez seja possível dizer, aliás, que as três primeiras parcerias de Tom e Chico representam a liquidação da bossa nova e sua época". MAMMì, Lorenzo. "Canção do Exílio". In: Três Canções de Tom Jobim. São Paulo: Cosac Naify, 2004, p. 12. O contraste entre o trecho da crônica e a canção é patente: enquanto a primeira relaciona o sabiá como motivo de esperança, a segunda parece retomar o poema romântico num sentido oposto ao do original, revelando uma profunda desilusão do sujeito lírico. Talvez esse contraste se deva à distância temporal entre ambas: enquanto a crônica é publicada nos anos JK, a canção é lançada meses antes de ser publicado o Al-5. As duas, no entanto, já parecem apontar para os descaminhos de nossa modernização.
} 
expressão "e partiu" no fecho de cada parágrafo pode ser considerada uma epístrofe, técnica que consiste na repetição de termos no fim dos versos de um poema e que serve, aqui, para conferir ênfase ao que se quer dizer. É um dentre outros procedimentos poéticos que Rubem Braga costuma empregar e que podem ajudar a definir a sua como uma crônica lírica.

A essa altura, já podemos ver se delineando alguns dos traços definidores do texto: em visita a um lugar, o cronista contrapõe um passado rígido e aristocrático a um presente de natureza exuberante e ágil. Mas, embora rígido, o passado é também faustoso. A natureza permanece no presente, e também serve para evocar o passado romântico de Gonçalves Dias. O presente, sofisticado, tem música e uísque.

Já no terceiro bloco, é interessante como o cronista idealiza aquele passado: são as fortes chuvas que acabaram com os cafezais e, como resultado, "os negros libertos viraram erosão social e as casas imensas ficaram mal-assombradas". Ou seja, o narrador considera que a ação da natureza acabou com as plantações e, por consequência, com o problema da escravidão, apenas deixando para trás as fazendas vazias. É bem verdade que o arranjo do texto não estabelece uma relação de causa e efeito: como já observamos, a opção por orações coordenadas tem como função evitar o conflito e conciliar posições. Acaba-se por não enfrentar o problema, dispondo fatos já dados um ao lado do outro e atribuindo à natureza uma força histórica. Por outro lado, a abordagem desproblematizada do passado escravocrata parece desempenhar uma função poetizante, construindo uma imagem idealizada que pode servir tanto de crítica ao presente como de projeção utópica futura.

O passado é mais uma vez referido quando o cronista aborda as gerações ligadas à fazenda: seus antigos donos são tidos por "fidalgos", e tanto mais quanto maiores fossem suas senzalas e suas plantações. Já seus herdeiros são levados em menor conta: como não sabem lidar com a terra, o cronista crê que migrarão para a cidade "para um emprego em qualquer iapeteque". Embora o cronista diga que nem os barões do café nem seus netos saibam plantar café, há um peso maior na crítica às novas gerações. Assim, ele parece contrastar aqui uma aristocracia rural de opulência e nobreza, talvez um pouco irresponsável nas técnicas de plantação e ligeiramente austera, a uma geração que vai se tornar burocrata no contexto rebaixado da cidade.

Apesar da destruição por novas e velhas gerações, o cronista constata a permanência da natureza no presente, no quarto bloco do texto. Vegetação, céu, rios e animais continuam a existir. Ele contempla o voo de andorinhas e faz menção implícita a 
Manuel Bandeira, citando um de seus poemas mais conhecidos ${ }^{56}$. Em seguida, divaga sobre os ninhos desses pássaros, feitos nas casas, e indaga onde eles moravam quando não havia casas. A arquitetura moderna, que tem a funcionalidade como um de seus aspectos, é criticada pelo cronista, que diz que nenhuma casa é funcional se não tiver espaço para o ninho da andorinha ${ }^{57}$. Ainda uma vez, o presente moderno é criticado desde uma perspectiva da preservação natural, do passado rural, com as casas de fazenda dos coronéis e velhos barões sendo apontadas como mais propícias ao ninho da andorinha. Adiciona-se ao final o elemento religioso, que também é considerado de uma perspectiva pretérita, com as velhas igrejas sendo consideradas o habitat ideal das andorinhas.

No quinto bloco da crônica, o cronista assiste à lua nascer e pensa que poderia amar a "sinhá" de um retrato da casa. Porém, ressalva que, se fosse daquele tempo, ela seria a "moça fazendeira" e ele, apenas "um colono pobre e feio, meio barbudo e calado". É interessante essa notação: no mesmo passo em que qualifica positivamente a proprietária da fazenda (ela é "bela", "linda", "moça", além de ser tratada pelo simpático pronome de "sinhá"), o cronista imagina-se como o colono, a um tempo se autodepreciando, de maneira irônica, e depreciando a classe de homens livres pobres. O cronista inclusive destaca a impossibilidade amorosa, pois a estratificação da sociedade daquele tempo (não que, de lá para cá, tenha havido mudança significativa) impedia que um agregado constituísse laços com a proprietária que o tinha sob sua guarda.

A constatação desse amor impossível deixa o cronista triste e como que coloca para ele uma perspectiva mais realista, para longe das divagações anteriores: a saída da varanda da fazenda interrompe a idealização do passado rural aristocrático, assim como o abandono da contemplação da lua suspende a exaltação à natureza. A volta "ao governo Kubitschek", por sua vez, marca o retorno ao contexto urbano e ao tempo presente. Ou seja, mesmo os anos dourados do período juscelinista são penosos se comparados àquele passado rural idealizado. É sintomático que o cronista, ao retratar esse passado, dê maior relevo aos proprietários e apenas mencione brevemente a escravidão e os homens livres pobres, ainda que se identifique mais a estes. Tal estratégia parece cumprir a função de escamotear o que pudesse haver de conflitivo naquela sociedade.

\footnotetext{
56 "Andorinha lá fora está dizendo:/ - 'Passei o dia à toa, à toa...'// Andorinha, andorinha, minha cantiga é mais triste!/ Passei a vida à toa, à toa..." (BANDEIRA, Manuel. "Andorinha". Libertinagem \& Estrela da Manhã. Rio de Janeiro: Nova Fronteira, 16ª reimp., 2000, p. 54). A referência implícita torna o texto menos pedante, pois não invoca o argumento de autoridade. Além disso, o emprego do artigo definido pode dar a ver a centralidade de Manuel Bandeira em suas crônicas, como o poeta por excelência e não um qualquer.

${ }^{57} \mathrm{~A}$ crítica à arquitetura moderna é recorrente nas crônicas de Rubem Braga. O assunto será retomado mais à frente.
} 
Acrescente-se que o sabiá e a andorinha, aqui, fazem figura desse passado idealizado a que é possível retornar por um simples passeio de fim de semana ao interior. Eles representam não só a permanência no presente de um passado rural, como também aludem à nossa história literária, fazendo referência a dois de nossos principais poetas, Gonçalves Dias e Manuel Bandeira. Essas referências também cumprem a função do argumento prestigioso, falando mais sobre o lugar social do narrador do que propriamente da paisagem descrita. A fidalguia dos barões do café, contígua a esse tempo, é por sua vez nostalgia de um modo de vida superior, embora o cronista os critique pelo modo destrutivo como plantavam café - mas não pela mão de obra que utilizavam, qual seja, o escravo. As novas gerações, por seu turno, estão fadadas a trabalhar na cidade em alguma repartição burocrática.

Assim, presente e passado são criticados, embora este em menor voltagem. 0 passado é rígido e convencional, mas nobre. O presente é vivaz e ágil, mas apenas no contexto da natureza, pois no ambiente urbano é rebaixado. O passado literário é digno, embora nem os donos da fazenda nem seus descendentes saibam preservá-lo. Igualmente, o presente é autêntico e sofisticado, embora inacessível, obviamente, para os antigos donos da fazenda.

Pode-se dizer, dessa maneira, que o cronista se identifica mais com os proprietários da fazenda do que com os descendentes deles, possivelmente seus contemporâneos, estabelecidos na cidade para trabalhar em alguma repartição burocrática. É interessante observar que essa bem poderia ser a trajetória do próprio cronista, que no entanto não se vê a si mesmo cumprindo esse itinerário - ao contrário, ele faz parte de uma camada ilustrada, íntima da tradição literária brasileira. Podemos ver aqui configurada uma elite cultural que procura se opor a uma elite econômica, contemporânea dela, embora decadente, mas cujos antepassados, estes, sim, merecem celebração.

Em certa medida, aqui se delineia uma figura cara à tradição literária nacional do século 20, o "fazendeiro do ar", como observou Roberto Schwarz. Tomada de empréstimo a um livro de poemas de Carlos Drummond de Andrade, a alcunha define, para o crítico, "o homem que vem da propriedade rural para a cidade, onde recorda, analisa e critica, em prosa e verso, o contato com a terra, com a família, com a tradição e com o povo, que o latifúndio the possibilitara" 58 .

\footnotetext{
${ }^{58}$ SCHWARZ, Roberto. "Cultura e política, 1964-69", O pai de família e outros estudos. São Paulo: Companhia das Letras, 2008, p. 110.
} 
Creio não forçar muito a nota ao incluir Braga nessa tradição. Se por um lado pode soar exagerado dizer que sua família era latifundiária, como era o caso de Drummond, por outro não se podem esquecer suas origens rurais, de vida na província. Numa crônica, Braga fala sobre essa origem: "Meu pai foi durante algum tempo sitiante, minha mãe era filha de fazendeiro, meus tios eram todos da lavoura..." 59 . Em outra, o cronista lembra, talvez contraditoriamente, que ele nasceu no contexto urbano, na cidade de Cachoeiro do Itapemirim. "Mas sempre a gente continua um pouco da lavoura, como um sitiante que perdeu a terra ou um colono despedido da fazenda"60, ressalva. Também há referência ao passado rural em "Na fazenda do Frade"61, em que o cronista conta a visita à antiga fazenda do avô, que está em ruínas mas ainda é habitada por uma família de colonos. O narrador passa a rememorar sua infância naquele lugar, que tinha uma "grande mesa preta", com a família sentada "ao longo dos longos bancos", e onde corria um murmúrio - "a bênção, a bênção, Deus te abençoe, boa noite, boa noite, a bênção". O trecho figura bem a extensa família, a parentela típica daquele contexto rural.

Em prefácio a uma coletânea de cronistas brasileiros para uma editora portuguesa, John Gledson sugere que Rubem Braga pertence à mesma geração de "fazendeiros do ar" de Carlos Drummond de Andrade. Com isso, o crítico inglês quer dizer que algumas das crônicas de Braga "recendem tanto ou mais a este mundo rural profundamente diferente do outro mundo, urbano e moderno, em que vieram a viver"62.

O que talvez marque uma diferença significativa é que, ainda que tenha passado a infância num contexto rural, sua família não era de ricos fazendeiros, mas sim de camadas mais pobres. Seu pai, porém, foi proprietário de um jornal local, onde Braga inclusive iniciou sua carreira na imprensa, e posteriormente chegou a ser prefeito de Cachoeiro do Itapemirim. É uma situação que coloca o cronista numa posição de privilégio, que pode ser considerada em alguns casos, embora não deva ser tomada como critério absoluto para avaliar a sua obra ${ }^{63}$.

\footnotetext{
59 BRAGA, Rubem. "O boi velho". A traição das elegantes, op. cit., p. 121-123.

${ }^{60}$ Id., "Justiça seja feita", O Homem Rouco. 2a ed., Rio de Janeiro: Ed. do Autor, 1963, p. 25.

${ }^{61}$ Id., "Na fazenda do Frade", A traição das elegantes, op. cit., p. 49-51.

62 GLEDSON, John. "Apresentação". In: Lisboa: Cotovia, 2006, p. 27-28.

${ }^{63}$ Apoio-me no prefácio de Antonio Candido ao estudo de Sergio Miceli sobre os intelectuais e a classe dirigente no Brasil, especialmente o trecho: "O papel social, a situação de classe, a dependência burocrática, a tonalidade política - tudo entra de modo decisivo na constituição do ato e do texto de um intelectual. Mas nem por isso vale como critério absoluto para os avaliar. A avaliação é uma segunda etapa e não pode decorrer mecanicamente da primeira. Apesar da cautela metodológica e do esforço para ver com clareza, Miceli incorre por vezes nessa contaminação hermenêutica." CANDIDO, Antonio. "Prefácio". In: MICELI, Sérgio. Intelectuais à brasileira. São Paulo: Companhia das Letras, 2001, p. 73-74.
} 
Em ensaio dedicado ao primeiro romance de Cyro dos Anjos, Schwarz analisa de perto essa figura ${ }^{64}$. $O$ crítico observa em $O$ Amanuense Belmiro que os dois primeiros capítulos do romance têm uma dinâmica arisca, com uma prosa desenvolta e rápida. No terceiro capítulo, porém, quando o protagonista relata a mudança do campo para a cidade, começam a surgir problemas. Schwarz identifica na passagem do rural para o contexto urbano a causa dessa dificuldade, porque o que poderia ser figurado de maneira dramática, com crises e conflitos, termina por se configurar de modo lírico, como "evocação saudosa" do passado e "decomposição do presente". Assim, a subjetivação extremada acaba por engendrar apenas um "movimento atmosférico da memória e da divagação", prejudicando o andamento da prosa. Parece evidente que o que Cyro dos Anjos conta é o próprio processo da transferência de certa geração, que, filha do senhorio rural, se tornou escritor na cidade.

Talvez não surpreenda que as primeiras aparições do protagonista do romance, Belmiro Borba, tenham ocorrido em crônicas, como lembra Ivan Francisco Marques. Como se sabe, o gênero favorece a escrita da intimidade, como a confissão ou o diário. Em estudo sobre o movimento modernista em Minas Gerais, o crítico afirma que uma das principais realizações de Cyro dos Anjos foi ter transposto "em alto nível para a prosa o temperamento gauche que vincou profundamente a nossa poesia moderna". Marques cita passagens de O Amanuense Belmiro que aludem a poemas dos primeiros livros de Drummond, como no trecho "E sou sempre gauche. Quando converso, as melhores ideias ficam cá dentro, sem encontrar expressão". A sentença ecoa o "Poema de Sete Faces" e a composição "Poesia", na qual o sujeito lírico gasta o tempo pensando num verso "que a pena não quer escrever" e que, entretanto, "está cá dentro"65.

Não à toa, o "fazendeiro do ar" por excelência era Carlos Drummond de Andrade, que cunhou a expressão usando-a como título de um de seus livros de poemas ${ }^{6}{ }^{6}$. Vagner Camilo aborda como a poesia do escritor mineiro está ligada a essa figura, procurando os fundamentos sociais que o colocam nessa posição. Sumariando o argumento de Schwarz, Camilo pontua também o que distingue Drummond do romancista mineiro: a maneira "extremamente conflituosa" na qual essa condição é experimentada, com o "confronto aberto de posições", distante portanto da acomodação do amanuense. Diferentemente do lirismo rememorativo do romance de Cyro dos Anjos, em Drummond o registro lírico ganha

\footnotetext{
${ }^{64}$ SCHWARZ, Roberto. "Sobre O Amanuense Belmiro", O pai de família e outros estudos. São Paulo: Companhia das Letras, 2008, p. 9-21.

${ }^{65}$ MARQUES, Ivan. Cenas de um modernismo de província. Drummond e outros rapazes de Belo Horizonte. São Paulo: Ed. 34/FFLCH-USP, 2011, p. 201-203.

${ }^{66} \mathrm{O}$ volume foi publicado em 1954.
} 
ares de "encenação dramática", figurando uma "estética da violência e da inquietude regida pelo signo de uma culpa"67. De acordo com Camilo, as raízes históricas da culpa nascem tanto da herança rural da família mineira, de que Drummond é não só um desvio como também uma espécie de traidor, quanto da exigência de participação na vida política do país como intelectual, justamente combatendo as velhas estruturas patriarcais.

À parte as diferenças em relação ao romancista mineiro, seria esse então o chão histórico em que caminha o gauche drummondiano. $\mathrm{O}$ aspecto conflituoso, observa Camilo, vai amainar a partir de Claro enigma e, com o distanciamento do passado familiar, praticamente se extinguirá nos livros seguintes, até chegar à poesia memorialística da série Boitempo, à qual o autor dá "tonalidades de crônica"68. Mais distendida, a prosa de Drummond não guarda as tensões de sua produção poética daqueles primeiros livros, como observou Antonio Candido ${ }^{69}$, embora possam ser contemporâneas deles.

A transição do campo para a cidade é bem identificada por Sérgio Miceli em seu livro sobre as relações entre as classes dirigentes e os intelectuais, no qual afirma que a decadência rural vivida em contexto urbano por muitos de nossos romancistas vai obrigálos a procurar "empregos no serviço público, na imprensa e nos demais ofícios que se 'prestam a divagações do espírito'. Assim, é a partir desse lugar que vão colher material para as suas "veleidades literárias", que ganharão forma em "diários mantidos em segredo" ou em "escritos encomendados por jornais e políticos venais"70.

Essa situação vivida por muitos de nossos escritores também é apontada por Mário de Andrade no balanço que faz da produção literária de sua época, em "A elegia de abril". Nesse ensaio, Mário indica aspectos problemáticos nos heróis de diversos romances brasileiros de então, onde constata que o protagonista é invariavelmente um "indivíduo desfibrado, incompetente para viver", "seres sem força nenhuma". Os heróis da literatura europeia, por sua vez, são "seres dotados de ideais, de ambições enormes, de forças morais, intelectuais, físicas" e, embora também fracassem, lutam contra "forças maiores". Mário de Andrade acredita haver nos romancistas brasileiros "a intuição insuspeita de

\footnotetext{
${ }^{67}$ CAMILO, Vagner. "O fazendeiro do ar e o legado da culpa", In: José Antonio Pasta Jr. e Jacqueline Penjon, Littérature et modernisation au Brésil, p. 211. As expressões em itálico, Vagner Camilo as toma de empréstimo a Antonio Candido (“Inquietudes na poesia de Drummond”, Vários Escritos, São Paulo: Livraria Duas Cidades, 1995, p. 144).

${ }^{68}$ A expressão é de Antonio Candido ("Drummond prosador". Recortes. Rio de Janeiro: Ouro Sobre Azul, 2004, p. 20).

${ }^{69}$ Ibid., p. 22-23.

${ }^{70}$ MICELI, Sergio. Intelectuais à brasileira, op. cit., p. 160.
} 
algum crime, de alguma falha enorme", e esse padrão o leva a considerar a "desistência" como verdadeiro tema ${ }^{71}$.

Ivan Marques nota, aliás, que a figura do herói fracassado vai chegar até os anos 1950 e se constituirá em verdadeira linhagem do romance nacional. Para exemplificar, Marques cita crítica de João Cabral de Melo Neto sobre o romance $O$ braço direito, de Otto Lara Resende, na qual o poeta lamenta a "descrição vazia" de uma "vida vazia"72 na obra do escritor mineiro.

As tendências de escapismo, a rememoração da infância no campo contraposta ao cotidiano rebaixado na cidade, o refúgio no espaço isolado da casa para se proteger dos choques da metrópole, a nostalgia de certo comunitarismo nas relações travadas no espaço rural em face da solidão urbana, tudo isso parece confirmar que o princípio lírico de Rubem Braga pode se entroncar na literatura da decadência rural.

1.3 Imprensa e história - integração nacional, indústria cultural e autonomia da crônica

Em "O presidente voador"73, Rubem Braga se posiciona favoravelmente ao fato de 0 então presidente Juscelino Kubitschek viajar pelo país e encontrar o povo.

\section{O presidente voador}

Olhem, para falar verdade, eu acho bom essa coisa de viver o nosso presidente a esvoaçar para um lado e outro do Brasil. Não sei por que, mas anima o interior e conforta o país, esse presidente volante que sorri cada dia em um município, dá abraços, come seu frango ao molho pardo e angu, inaugura um troço qualquer, diz coisas otimistas. Na minha opinião isso só pode exaltar, como é uso dizer agora.

O Brasil já é de natural triste, com sua gente perdida pelas imensidões melancólicas; ficaria pior com um presidente casmurro e imóvel dentro do Palácio.

A oposição, que é mal-humorada por princípio, diz que assim o presidente não tem tempo para se concentrar no estudo de nossos problemas, não pode governar.

Por mim, eu prefiro um presidente voando a dois na mão. Voando, ele é um anjo federal, que não faz mal a ninguém, obriga a festinhas com banda de música e champanha. Sempre sobram uns docinhos para as crianças.

Ah, eu fui criança no interior e jamais peguei sequer uma visita de presidente do Estado; lembro-me, entretanto, de minha alegria quando apareceu lá em Cachoeiro o secretário da Educação do Estado. Era o velho Ubaldo Ramalhete, alto, ereto, bem vestido. Foi a primeira personalidade que eu vi. E achei ótimo aquilo, os foguetes na estação, a formatura do Grupo Escolar e das escolas, nós todos ali, e banda de música, Hino Nacional, guaraná grátis, o prefeito, o juiz, todos os locais bem vestidos, cumprimentando, sorrindo, dizendo por favor, por obséquio, tenha a

\footnotetext{
${ }^{71}$ ANDRADE, Mário de. "A elegia de abril”. In: Aspectos da Literatura Brasileira. 5. Ed., São Paulo: Martins, 1974, p. 190-191.

${ }^{72}$ MARQUES, Ivan Francisco. "Herói fracassado: Mário de Andrade e a representação do intelectual no romance de 30", Teresa, nำ16, 2015, p. 71.

${ }^{73}$ BRAGA, Rubem, Ai de ti, Copacabana!, op. cit., p. 51-53.
} 
bondade, vossa excelência, todos felizes. E quando Sua Excelência falou de Cachoeiro de Itapemirim só disse coisas a nosso favor, senti-me importante pela importância de minha cidade indubitavelmente ou inquestionavelmente (não me lembro mais, era um desses advérbios de modo assim bonitos, um advérbio de discurso) um grande centro progressista industrial cultural, outros adjetivos em al, e uma alusão delicada ao sorriso e à graça da mulher cachoeirense.

Ubaldo Ramalhete, que mais tarde conheci melhor, era um homem inteligente e fino; mas que não fosse, fosse quem fosse - era um secretário de Estado, uma personalidade, uma excelência; imaginem se fosse Presidente da República!

Por que roubar uma alegria tão grande às crianças humildes do interior do Brasil? E os senhores da oposição têm certeza de que seria melhor para o Brasil se o doutor Juscelino voasse menos e pensasse mais? Tenho minhas dúvidas.

Voai, presidente, voai!

Rio, janeiro, 1957.

Em tom coloquial, interpelando de saída os leitores de maneira a iniciar uma conversa, o cronista emite uma opinião positiva a respeito de viagens do presidente, talvez contrariando o senso comum. As razões para o otimismo são colocadas de modo um tanto indefinido: o cronista não sabe bem por quê, mas cogita que faz bem ao país um presidente que "sorri cada dia em um município", "inaugura um troço qualquer, diz coisas otimistas".

O país triste por natureza, diz o narrador, com sua "gente perdida pelas imensidões melancólicas", seria pior "com um presidente casmurro e imóvel". O cronista coloca então um contraponto: a oposição diz que, viajando, o presidente não teria tempo para o estudo de nossos problemas e para governar. E reitera sua posição com a paráfrase invertida de um dito popular ("Por mim, prefiro um presidente voando a dois na mão"), gracejo que convoca ao riso mas que cumpre função diversionista, de não responder propriamente aos questionamentos da oposição. Ao fim, o cronista retoma uma expressão de uma célebre crônica de sua autoria, na qual incitava um passarinho, que roubara uma medalha de condecoração de um vetusto conde, a sair voando pelos $\operatorname{ares}^{74}$.

A figura do passarinho, ou do sabiá, é recorrente na obra de Braga, a ponto de o cronista mesmo ter ganhado o epíteto de "sabiá da crônica". Nesta crônica, por sua vez, é o presidente quem emula as características de um pássaro75: "a esvoaçar para um lado e outro", toma seu lugar na paródia do dito popular e também é definido como um "anjo federal".

\footnotetext{
74 "Voai, voai, voai por entre as chaminés do conde, varando as fábricas do conde, sobre as máquinas de carne que trabalham para o conde, voai, voai, voai, voai, passarinho, voai." BRAGA, Rubem. "O conde e o passarinho", $O$ conde $e$ o passarinho e Morro do Isolamento. 5 ed., Rio de Janeiro: Record, 1982, p. 73-74.

${ }^{75}$ Veja-se, a título de comparação, a mesma figura retomada por outra escritora: “...O que o senhor Juscelino tem de aproveitável é a voz. Parece um sabiá e a sua voz é agradável aos ouvidos. E agora, o sabiá está residindo na gaiola de ouro que é o Catete. Cuidado sabiá, para não perder esta gaiola, porque os gatos quando estão com fome contempla as aves nas gaiolas. E os favelados são os gatos. Tem fome”. JESUS, Carolina Maria de. Quarto de Despejo. 9a ed.,Rio de Janeiro: Francisco Alves, 1963, p. 27. As diferenças na representação são marcantes: enquanto o cronista exalta os voos do presidente, a escritora imagina em JK um sabiá engaiolado pronto a ser devorado por gatos, estes representando "favelados" com fome.
} 
Vale ressaltar que a imagem de animais que voam é frequentemente evocada por cronistas, que muitas vezes até identificam sua maneira de escrever a movimentos do voo de um pássaro ou de um inseto. José de Alencar, por exemplo, compara o cronista ao colibri e, mais tarde, Machado de Assis retoma o símile, numa das definições mais célebres do ofício:

\begin{abstract}
"O folhetinista, na sociedade, ocupa o lugar do colibri na esfera vegetal: salta, esvoaça, brinca, tremula, paira, espaneja-se sobre todos os caules suculentos, sobre todas as seivas vigorosas. Todo o mundo the pertence, até mesmo a política."76
\end{abstract}

A esta altura, podemos ver se estabelecendo dois polos semânticos na crônica: de um lado (do lado do presidente e do cronista), alegria, agilidade e derrisão e, de outro (da oposição e dos que pensam como ela), tristeza, imobilidade, mau humor.

Assim, para emitir uma opinião polêmica, o cronista primeiro cria intimidade com o leitor para ganhar a sua adesão; propõe que o país naturalmente triste precisa da alegria ubíqua do presidente; como contraponto, coloca as vozes contrárias para em seguida as deslegitimar, sem propriamente respondê-las; lembra da alegria ingênua de sua infância por ocasião da visita, à sua cidade natal, de uma personalidade política, que profere um discurso pomposo e populista; mostra não se importar com as qualidades de um homem público, mas com sua posição; coloca em dúvida se seria melhor que o presidente viajasse menos e pensasse mais. Estranhamente, a insolência com os poderosos, recorrente em suas crônicas, dá lugar à exaltação e ao populismo, aspectos mais afeitos à propaganda política. Ao relembrar sua infância, o cronista adota o ponto de vista das crianças humildes do interior, de certo modo infantilizando o leitor. No mesmo passo, ao tratar por "doutor Juscelino" o presidente, o cronista adere de maneira acrítica às suas viagens, reforçando uma postura paternalista.

Por outro lado, o cronista também parece querer incutir uma aproximação entre crianças e personalidades políticas, entre a população mais humilde e figuras importantes, entre interior modorrento e capital pujante. Trata-se de um desejo de integração, de incluir no ritmo geral do país a "gente perdida pelas imensidões melancólicas". Presente no horizonte da época, a imaginação de uma comunidade nacional, vista com os olhos de hoje, pode soar um tanto ingênua.

É importante lembrar que a crônica foi publicada na revista Manchete, na época um dos veículos que mais propagandeavam as realizações do governo JK. Surgida nos anos

\footnotetext{
${ }^{76}$ ASSIS, Machado. "Aquarelas - O folhetinista", in John Gledson (organização, introdução e notas), Machado de Assis: crônicas escolhidas, São Paulo: Penguin Classics Companhia das Letras, 2013, p. 45
} 
1950, ao longo da década a revista viria a superar sua concorrente $O$ Cruzeiro, até então principal publicação do tipo, criada em 1928 ${ }^{77}$. Na primeira edição de Manchete, o editorial anunciava em tom ufanista: "Em todos os números daremos páginas em cores, para que essas cores se ponham sistematicamente a serviço da beleza do Brasil e das manifestações de seu progresso"78. A primazia em sua área foi conquistada justamente quando Manchete passou a publicar reportagens eufóricas sobre a construção de Brasília, com várias páginas dedicadas ao assunto e material fotográfico extenso. Com isso, a publicação acabou se tornando o principal veículo de propaganda do governo de Juscelino Kubitschek, com quem o dono da revista, Adolpho Bloch, tinha estreitas relações de amizade $^{79}$.

De fato, a revista investiu pesadamente na promoção do governo JK. Foi a primeira empresa jornalística a implantar uma sucursal em Brasília. A partir de 1958, lançou edições especiais sobre a construção da cidade e, na inauguração da nova capital, em 1960, a tiragem alcançou 760 mil exemplares ${ }^{80}$. Quando entregou em mãos essa edição ao presidente, Adolpho Bloch fez um agradecimento, pois sabia que, a partir de então, a revista se tornaria "verdadeiramente nacional"81.

Sem entrar na discussão sobre as relações promíscuas entre imprensa e poder político, a revista acabava desempenhando papel importante, até pela posição que então passou a ocupar, em imaginar uma comunidade nacional. É bem verdade que se tratava da construção de uma ideia de nação que passava ao largo do debate público, funcionando antes como construção de um imaginário vendável para consumo ${ }^{82}$. Talvez seja possível dizer que as semanais ilustradas de certa forma antecipam o que outros setores da indústria

\footnotetext{
77 Cf. ORTIZ, Renato Ortiz. A moderna tradição brasileira. São Paulo: Ed. Brasiliense, 1994, p. 38-48. O autor aponta os anos 1940 como o início de uma sociedade de massas no Brasil, porque é nesse momento que se consolida o que os sociólogos chamam de sociedade urbano-industrial. Ortiz elenca uma série de dados nas áreas de cinema, publicidade, TV e rádio que mostram a expansão da indústria cultural no Brasil naquela década e na seguinte. Assim também ocorre com o mercado de publicações, com o aumento do número de jornais, revistas e livros. Ortiz cita como exemplo a tiragem da revista Cruzeiro, que passa de 300 mil exemplares em 1948 para 550 mil em 1952.

${ }^{78} \mathrm{BLOCH}$, Arnaldo. Os Irmãos Karamabloch, São Paulo: Companhia das Letras, 2008, p. 168

79 lbid., p. 168.

${ }^{80}$ ABREU, Alzira Alves. "Revisitando os anos 50 através da imprensa", BASTOS, Élide Rugai; BÔAS, Gláucia Villas; BOTELHO, André (org.). O moderno em questão: a década de 1950 no Brasil, Rio de Janeiro: Topbooks, 2008, p. 218.

${ }^{81}$ Cf. BLOCH, Arnaldo, op. cit., p. 202.

82 Inspiro-me aqui na periodização feita por Paulo Arantes por ocasião do lançamento da revista Rodapé, em 2002, em que o crítico debate a inserção da revista naquele contexto histórico, em que já não existe a referência nacional. Como se sabe, a inflexão se dá no pós-1964, que inaugura o momento contemporâneo em que ainda se vive. Talvez seja interessante transcrever o trecho: "Passamos desse Print Capitalism para um capitalismo, digamos, de imagens, em que a nação torna-se ainda mais impalpável. Ela passa a ser não mais uma comunidade imaginada/pensada através desse raciocínio fixado no discurso impresso, no debate público acerca do valor das obras, mas uma comunidade imaginária no sentido lacaniano. O corpo nacional é tão imaginário quanto o corpo na tópica de Lacan. O paradoxo é esse: na época da oligarquia burguesa liberal, você lia o Estado de S. Paulo e havia simbolização da experiência. Quando a massa trabalhadora entra, essa esfera pública explode e se dá início à indústria cultural. Passa-se da reflexão ao consumo, cada vez mais, consumo de imagens. E essas imagens cristalizam o corpo imaginário da nação. ARANTES, Paulo et al., "Crítica de Intervenção", Rodapé, n. 3, nov/2004, p. 17.
} 
cultural (como a TV, a publicidade estatal) realizariam de maneira mais contundente anos depois, a saber, a elaboração do ideal do Brasil Grande. Ou seja, há continuidade aí, mas com inversão de sinais - como se sabe, a partir de 1964 a integração de ricos e pobres já está rifada, e a massa trabalhadora é incorporada apenas na esfera da sociedade de consumo.

Além de Rubem Braga, pela Manchete passaram os principais cronistas da época: Henrique Pongetti - que também foi editor-chefe da revista, em seu início -, Carlos Drummond de Andrade, Fernando Sabino, Paulo Mendes Campos ${ }^{83}$. A maioria pertencia, de algum modo, a certa tradição modernista que por um período acreditou que seria possível conciliar um processo modernizante e preservar uma sociabilidade antiga, de tipo cordial, crendo também numa futura integração entre ricos e pobres - promessa que 0 desenvolvimentismo de JK procurava levar a cabo. Com efeito, buscou-se na época modernizar a parte dita atrasada do país, com a criação da Superintendência do Desenvolvimento do Nordeste, cujos planos consistiam em promover avanços para que essa região se equiparasse ao Sul, já mais urbano e industrializado. (Como se provaria mais tarde, no entanto, tudo não passava de ilusão, embora com efeito de verdade acreditava-se, à época, que desempenhava papel efetivo no processo histórico.)

Na crônica "Sizenando, a vida é triste"84, o narrador acorda cedo pela manhã e se entusiasma com aulas de esperanto dadas na rádio que está ouvindo. O professor lê uma carta enviada pelo ouvinte Sizenando Mendes Ferreira, de Goiás, que acha o curso interessante e quer se inscrever como aluno. O cronista se comove com a situação:

“(...) naquele instante mesmo, a um mundo de remotas léguas, no interior de Goiás, havia um Sizenando, brasileiro como eu, aprendendo que o jardeno está plena de floroi - e talvez escrevendo isso em um caderno."

É impressionante a semelhança do trecho com os "Dois poemas acreanos"85 (Clã do Jabuti, 1927), de Mário de Andrade. No primeiro poema, "Descobrimento", o sujeito lírico está sentado à sua escrivaninha, em sua casa em São Paulo, quando se lembra do seringueiro do norte do País. "Esse homem é brasileiro que nem eu", assevera. Já na segunda parte do poema, "Acalanto do seringueiro", o poeta entoa uma cantiga para fazer o trabalhador dormir, embora os hábitos e costumes diferentes tornem difícil a aproximação.

\footnotetext{
${ }^{83}$ BLOCH, Arnaldo, op. cit., p. 168.

${ }^{84}$ BRAGA, Rubem, Ai de ti, Copacabana!, op. cit., p. 117-120.

${ }^{85}$ ANDRADE, Mário de. Poesias Completas. São Paulo: Livraria Martins Editora, 1966. p. 150-153.
} 
Apesar de nunca tê-lo visto ou ouvido, o poeta considera o seringueiro "brasileiro que nem eu", um "amigo", a quem não pode restar indiferente.

A referência fica mais explícita na crônica "O chamado Brasil brasileiro"86, do livro Recado de Primavera (1984). Arrolando uma série de autores que pensaram o país, como Euclides da Cunha, Paulo Prado, Sérgio Buarque de Holanda e Oswald de Andrade, Braga transcreve um trecho de "Descobrimento", primeira parte dos "Dois poemas acreanos", de Mário de Andrade, os quais qualifica como uma "comovente confissão brasileira". E conclui: "essa fundamental solidariedade me impressionou".

Assim, apesar da distância, os escritores imaginam a nação em comum, tanto com o seringueiro acreano quanto com o aprendiz de esperanto em Goiás. Na imaginação dessa grande comunidade, "mesmo os membros da mais minúscula nação jamais conhecerão, encontrarão, ou sequer ouvirão falar da maioria de seus companheiros, embora todos tenham em mente a imagem viva da comunhão entre eles" 87 .

O que talvez marque a distinção entre os poemas e a crônica é que nesta o rádio desempenha papel primordial na imaginação comum da nação. A emissão sonora é o que deflagra na imaginação do cronista a associação a um brasileiro como ele, morador de Goiás. Por meio dela, os dois acordam cedo para aprender esperanto, enquanto outros patrícios, segundo o cronista, se dirigem para o trabalho, tomam café da manhã, dormem "insensatamente" ou, como sua amada Joana, saem do bar e entram no carro de outro homem. Ele e Sizenando, ao contrário, cultivam "o jardim da cultura" e, por isso, são em certa medida "a elite do Brasil". Aqui, o cronista busca uma vez mais a aproximação com Sizenando, os quais juntos formariam uma elite cultivada, em oposição à mundanidade de outros cidadãos, que cumprem a rotina habitual ou, a exemplo de sua amada, se divertem.

Apesar dessa polarização, na verdade o rádio funcionava como ponto de convergência entre cronista, ouvinte de uma região distante e a amada. O próprio Rubem Braga, na crônica "A língua do rádio"88, nota o tamanho da influência do veículo nos anos 1950. O cronista observa que a infância daquela época "aprendeu muita coisa na linguagem quase sempre pernóstica do rádio". E acrescenta que esse meio de comunicação unifica a linguagem no país como jamais se imaginara. "(...) a língua oficial falada no Brasil em todos os círculos sociais e em todos os estados é, afinal de contas, a da Rádio Nacional",

\footnotetext{
${ }^{86}$ BRAGA, Rubem. Recado de primavera. 4a ed. Rio de Janeiro: Record, 1986, p. 67-70.

87 ANDERSON, Benedict. "Introdução", Comunidades Imaginadas: reflexões sobre a origem e a difusão dos nacionalismos. São Paulo: Companhia das Letras, 2008, p. 32.

${ }^{88}$ BRAGA, Rubem Braga. Os moços cantam \& outras crônicas sobre música, op. cit., p. 90-91.
} 
assevera. De acordo com ele, para uma gíria se consolidar era preciso anteriormente que ela circulasse de boca em boca até chegar a uma letra de samba ou a uma revista de teatro. Já em seu tempo, o Estado ou uma empresa de rádio podia impor mesmo "um falso folclore, pré-fabricado"89. O autor lamenta a popularização do rádio sem que o tenha acompanhado nesse processo "nenhuma tradição intelectual ou cultural". É notável como, já naquele tempo, o cronista observa o desenvolvimento do rádio ao longo do tempo: com potencial para auxiliar no processo de integração do país, ele acaba se transformando em mero veículo difusor de mercadorias culturais.

Anteriores a esse período, os "Dois poemas acreanos", publicados em 1927, imaginam apenas literariamente a ligação entre o escritor paulista e o trabalhador do Norte do país. Já na década de 1950, a relação entre o cronista e o ouvinte goiano se dará por meio do rádio, que vinha se desenvolvendo desde os anos 1930 por iniciativa do governo de Vargas. Em meados do século, apesar de começar a assumir um caráter primordialmente mercadológico, o rádio, entre outros meios de comunicação, ainda podia contribuir para o projeto de integração nacional. Com o golpe de 1964, quando o populismo é tirado do poder pela aliança civil-militar, o rearranjo de forças descartará de vez os mais pobres - e a perspectiva de uma sociedade integrada sumirá do horizonte.

Em "As meninas"90, o narrador rememora uma cena, mas não sabe ao certo onde a presenciou. O primeiro parágrafo dá ideia do andamento cadenciado da crônica:

Foi há muito tempo, no Mediterrâneo, ou numa praia qualquer perdida na imensidão do Brasil? Apenas sei que havia sol e alguns banhistas; e apareceram duas meninas de vestidos compridos - o de uma era verde, o da outra era azul. Essas meninas estavam um pouco longe de mim; vi que a princípio apenas brincavam na espuma; depois, erguendo os vestidos até os joelhos, avançaram um pouco mais. Com certeza uma onda imprevista as molhou; elas riam muito, e agora tomavam banho de mar assim vestidas, uma de azul, outra de verde. Uma devia ter 7 anos, outra 9 ou 10; não sei quem eram, se eram irmãs; de longe eu não as via bem. Eram apenas duas meninas vestidas de cores marinhas brincando no mar; e isso era alegre e tinha uma beleza ingênua e imprevista.

A felicidade e a graça das meninas afastam a tristeza do cronista, e ele sente a necessidade de mostrar a cena a alguém, "repartir aquele instante de beleza como quem

\footnotetext{
${ }^{89}$ Observando os impasses que os meios de comunicação de massa traziam para a literatura nos países latinoamericanos, Antonio Candido nota que a alfabetização proporcionada pelo processo de urbanização talvez não angariasse mais leitores literários, os quais buscariam "no domínio do rádio, da televisão, da história em quadrinhos" - na indústria cultural, portanto - "os meios de satisfazer as suas necessidades de ficção e poesia". Assim, a população alfabetizada, junto com os analfabetos, passaria da "fase folclórica para essa espécie de folclore urbano que é a cultura massificada" (CANDIDO, Antonio. "Literatura e subdesenvolvimento", A Educação pela Noite, 5a ed. revista pelo autor, Rio de Janeiro: Ouro sobre Azul, 2006, p. 174).

${ }^{90}$ BRAGA, Rubem Braga, A traição das elegantes, op. cit., p. 81-82.
} 
reparte um pão, ou um cacho de uvas em sinal de estima e simplicidade; em sinal de comunhão".

Não há nenhuma referência aos fatos do dia anterior ou da semana, nenhuma localização precisa (uma praia do Brasil ou do Mediterrâneo?), nada que aluda à época do episódio (foi há muito tempo), o que remete a formas simples de narrativas. Mas também aí não seríamos exatos, pois tampouco há enredo, apenas a fixação de uma imagem, de um momento "precário e fugaz". Há a notação religiosa, com a alusão ao compartilhamento do pão ou do cacho de uvas, e o uso de vocábulos como estima, simplicidade e comunhão. Há graça e felicidade no quadro de beleza, mas o cronista sente uma "angústia indefinível", "suave e dolorosa". Essa tristeza, porém, lembra ao narrador que ele devia ser feliz naquela hora, porque aquele momento ia passar. E completa:

Foi talvez para fixá-lo, de algum modo, que pedi a ajuda de uma pessoa amiga; ou talvez quisesse dizer alguma coisa a essa pessoa e apenas the soubesse dizer: 'veja aquelas duas meninas...

Ou seja, o momento de beleza é experimentado pelo narrador triste e solitário, mas para fixar o instante ele pede ajuda a uma pessoa amiga. A fruição da beleza só pode se realizar na sua solidão de indivíduo, mas guardá-la depende da ajuda de alguém. Parece óbvio que o narrador que vivenciou aquele instante quer reparti-lo também com o leitor, ainda que não o interpele diretamente.

Nesta crônica de enredo esparso, podemos dizer que há a descrição do quadro de beleza, os sentimentos do narrador diante da lembrança da cena e o chamado ao outro para ajudar a fixar o momento. O instante de felicidade, como se viu, só pode ser guardado com a ajuda do outro, que pode ser um amigo ou o leitor com quem o narrador divide 0 relato. O único movimento do enredo, apenas sugerido, parece ser esse gesto em direção ao outro - ao leitor, indiretamente -, que é convocado ao exercício da sensibilidade, da percepção da beleza fugaz de uma cena idílica, quase atemporal.

Vemos aqui a criação de uma atmosfera lírica, livre de qualquer dado factual, uma representação impressionista em que quase se apagam os contornos entre as roupas de cores marinhas das meninas e as ondas do mar, a que se combina elementos voláteis como o vento e a areia. Esse "quadro de beleza", desenhado para a contemplação e o exercício da sensibilidade, é compartilhado com o leitor, o qual por sua vez ajuda o cronista a fixar a cena na memória, que de individual passa agora a coletiva. Esboça-se assim, ainda uma vez, aquela comunidade na qual não se conhecem leitor e cronista, embora este convoque aquele para comungar da beleza do quadro efêmero. 
A rarefação do dado factual vai no sentido de conferir autonomia literária ao gênero, que naquele momento, por meio de seus autores, procura se desligar das notícias do dia. Mas como a crônica passou de comentário dos fatos do dia a essa divagação tão subjetiva, a essa movimentação atmosférica entre a memória e o sonho? Quais as razões para que esse tipo de crônica tenha prevalecido entre outros? Por que ele se fixou como modelo naquela época?

Para responder a essas questões, cremos ser importante levar em conta as condições originárias de produção das crônicas naquele momento decisivo que foram os anos 1950 e 1960. Como se sabe, a imprensa da época passa por transformações técnicas fundamentais, que vão incidir ou influenciar a produção das crônicas. Luiz Roncari observou a marca da produção de ritmo industrial na crônica, chamando a atenção para o fato de que textos então vistos como literários podem ter originariamente combinado essa função com outros fins, "moralistas, publicísticos ou mercantis", para se adequar ao meio em que seriam publicados $^{91}$.

Para Roncari, a crônica literária se realiza na brevidade dos jornais, isto é, seu propósito repousa no veículo de comunicação para o qual foi concebida, ainda que o cronista preveja sua posterior publicação em livro. Por esse motivo, tem de ser pensada em função das notícias diárias, no diálogo com elas. O crítico traz alguns pontos que valem a pena ser elencados: a crônica tenta se diferenciar ocupando espaço fixo e mais largo do que a notícia, voltando-se a assuntos que passariam despercebidos, apelando para os caprichos da narração em primeira pessoa, usando da variedade de pequenos gêneros como diálogos, retratos, tipos, cenas, comentários, confissões.

Marcelo Coelho também vê na crônica uma espécie de "avesso, de negativo da notícia”. O jornalista diz que, enquanto a notícia procura destacar a importância de determinado fato, suscitar o debate, expressar um ponto de vista, a crônica vai insistir "na desimportância de tudo", afastar qualquer tipo de discussão, fixar um ponto de vista individual ${ }^{92}$.

Porém, essa mudança, ou esse contraste mais acentuado entre a crônica e outros gêneros praticados no restante do jornal, será mais visível apenas em meados do século passado. Com efeito, será na década de 1950 que a imprensa escrita vai adotar o modelo norte-americano em substituição ao modelo francês, que empregava uma escrita mais

\footnotetext{
${ }^{91}$ RONCARI, Luiz. "A estampa da rotativa na crônica literária”, Boletim Bibliográfico da Biblioteca Mario de Andrade, vol. 46, no 1 - 4, jan. dez. 1985, p. 9-16.

${ }^{92}$ COELHO, Marcelo. "Notícias Sobre a Crônica". In: CASTRO, Gustavo de; GALENO, Alex (org.); Jornalismo e literatura - A sedução da palavra, São Paulo: Escrituras, 2002, p. 155-162.
} 
literária, valorizava o comentário mais do que o relato factual e não separava graficamente os gêneros informativo e opinativo, como atesta Ana Paula Goulart Ribeiro.

Segundo a historiadora, esse modelo prevalecia porque, até meados do século XX, o jornal era a plataforma em que os escritores se exercitavam, construíam seu prestígio social e garantiam o seu sustento, já que o reduzido público-leitor não era suficiente para que os autores pudessem se dedicar exclusivamente à venda de seus livros para seu sustento. Além disso, a estudiosa ressalta também as fronteiras pouco definidas, nesse período, entre imprensa e poder político: na maior parte das vezes, o jornal era instrumento de pequenos grupos com interesses políticos ou mesmo do Estado ${ }^{93}$.

Assim, com a implantação do modelo norte-americano, valores como objetividade, imparcialidade, hierarquização das informações vão substituir a subjetividade, o estilo pessoal, a opinião. Esse modelo vai reorganizar a página do jornal e garantir espaço definido para os gêneros de opinião, geralmente nas primeiras páginas (editorial, artigo, coluna), e de reportagem, no interior do periódico (notícia, notas). No mesmo período, a abertura de faculdades de jornalismo no país vão formar os primeiros profissionais no ofício. Assim, poetas, romancistas, contistas, que antes também exerciam a função de jornalistas, agora passarão a escrever apenas no espaço reservado à crônica. Por abrigar escritores dos mais diversos gêneros, a crônica vai também ganhar formas variadas, nas quais o autor poderá imprimir seu estilo. Ligada inicialmente ao gênero opinativo, como uma espécie de comentário do dia ou da semana, o gênero vai progressivamente deixar de lado o dado factual para se deter na sua tão característica divagação subjetiva.

Mas a autonomização da crônica parece estar ligada também a estratégias editoriais, de seleção e republicação em livro. O critério, pelo menos no caso de Rubem Braga, parece ser o de privilegiar aquelas composições cujos dados factuais são mais rarefeitos. Tomemos a coletânea 200 crônicas escolhidas, publicada pela primeira vez em 1978. Se atentarmos para a seleção feita por Fernando Sabino, depois aprovada por Braga, poderemos observar que as crônicas de seus primeiros volumes, como $O$ conde e 0 passarinho (1936), Morro do isolamento (1944), Com a FEB na Itália (1945), Um pé de milho (1948), O homem rouco (1949) e A borboleta amarela (1953) figuram na coletânea em menor número, talvez porque nesse período (de 1932 a 1953) a crônica ainda estivesse de certa forma ligada ao comentário do dia ou da semana. A partir de A Cidade e a Roça (1957) até $A$ traição das elegantes (1967), época em que o gênero parece ir se desligando

\footnotetext{
93 RIBEIRO, Ana Paula Goulart. "Jornalismo, literatura e política: a modernização da imprensa carioca nos anos 1950", Estudos Históricos. Rio de Janeiro, n.31, 2003, p 147-160.
} 
do dado factual e passa a ganhar mais autonomia, as crônicas, na antologia, estão em maior quantidade.

Na seleção das crônicas de Ai de ti, Copacabana! para a coletânea, por exemplo, Rubem Braga descarta, salvo uma, aquelas escritas no Chile, quando era chefe do escritório comercial do Brasil naquele país. Nelas, há referências à cordilheira dos Andes, ao oceano Pacífico, a palavras em espanhol, ao local em que o cronista morou, a terremotos, à civilização inca. Todas essas são descartadas. A única que vai para a coletânea é a crônica "As luvas", que de resto não faz nenhuma referência ao Chile, exceto por uma frase em espanhol e por local e data postos ao fim. Já na seleção das crônicas de A traição das elegantes para a antologia, Braga descarta também aquelas escritas no período em que foi embaixador do Brasil no Marrocos.

Essa estratégia parece ser um modo de fixar o espaço de beira-mar carioca como lugar por excelência da crônica moderna. É possível sublinhar ainda a importância do Rio de Janeiro como referência nacional, já que a cidade era na época a capital do país. Com efeito, Margarida de Souza Neves cunhou o conceito de capitalidade para sublinhar a importância do então distrito federal. Nesse sentido, para a historiadora, "Rio de Janeiro" e "Brasil" seriam termos permutáveis, e uma questão referida ao país como um todo poderia ser exemplificada com uma referência à cidade que já foi sua capital políticoadministrativa ${ }^{94}$.

É possível ver outras estratégias em cartas trocadas entre os cronistas-amigos. Samantha dos Santos Gaspar analisou uma carta enviada a Rubem Braga por Otto Lara Resende, na qual este discute a seleção de crônicas para o volume As boas coisas da vida, de 1988. Nela, Lara Resende sugere a supressão de marcas que revelam a publicação originária no jornal (por exemplo, o uso da expressão "continua na semana que vem") e recomenda a junção de uma crônica seriada num único texto, assim como pondera o anacronismo de certas siglas (como AIB, de Ação Integralista Brasileira) e hábitos antigos estranhos ao leitor (pelo que se pode depreender, Rubem Braga fala de uma pessoa que tem cédulas no bolso, numa época em que as cédulas de votação, mais tarde impressas

\footnotetext{
${ }^{94}$ NEVES, Margarida de Souza, "História da crônica, crônica da História”. In: RESENDE, Beatriz (org.). Cronistas do Rio. Rio de Janeiro, Ed. José Olympio, 1995, p. 26-27.
} 
pela Justiça Eleitoral, eram levadas pelo cidadão). Em outra carta, esta mais sucinta, Fernando Sabino sugere cortar crônicas que "não fazem falta ou são muito datadas"95.

Voltando à crônica sobre as meninas na praia, é possível ver que não eram necessárias referências explícitas ao contexto histórico para ajudar a criar a atmosfera que tinha no horizonte a integração nacional. Evidentemente, o otimismo que dela recende não pode ser visto como mera propaganda política, embora a favoreça - ainda mais se considerarmos que a crônica foi publicada na revista que mais exaltou as realizações do governo de Juscelino Kubitschek, descartando princípios jornalísticos básicos, como a independência editorial e a fiscalização do poder político. Talvez seja um pouco exagerado ver no gesto do cronista de aproximação ao outro um chamado para a integração nacional. Mas, se lida em conjunto com aquela primeira crônica, na qual o narrador exalta as viagens do presidente, e que, aliás, não entra no volume 200 crônicas escolhidas, podemos ver como o texto pode prescindir da referência explícita para criar uma atmosfera, uma ambiência favorável ao clima político.

Se pensarmos, ainda, que ela foi escrita para um veículo passageiro, podemos imaginar que, mesmo que não tenha sido concebida para intervir na atualidade, a crônica acaba por incidir em seu tempo. Acresce que a referência ao rádio, na segunda crônica analisada, dá a medida da ressonância da mensagem de integração nacional, na qual cronista, sua amada e ouvinte de Goiás podem se imaginar como parte de uma mesma comunidade. Daí, pode-se concluir que a perspectiva de integração é muito favorecida pela expansão e consolidação da indústria cultural, da qual fazem parte tanto o sistema de radiodifusão, referido na crônica, quanto as revistas semanais ilustradas, que publicam os cronistas. No entanto, a consolidação dos meios de comunicação de massa no período já dá os indícios do caminho comercial que essa integração iria tomar - e, saberemos mais tarde, também pela via autoritária.

\footnotetext{
${ }^{95}$ GASPAR, Samantha dos Santos. "Rubem Braga e o semanário Comício: notas sobre uma experiência jornalística antivarguista nos anos 1950”, Anais do XXVI Simpósio Nacional de História - ANPUH, São Paulo, julho 2011 , p. 2.
} 


\section{Configuração lírica - temas e formas}

\subsection{A cidade e a roça}

Título de uma das principais coletâneas de Rubem Braga, A cidade e a roça são os polos cruciais nos quais as crônicas de Rubem Braga são ambientadas ${ }^{96}$. É interessante observar que, mais tarde, Braga mudará o título desse livro, alegando semelhança com $A$ cidade e as serras, de Eça de Queirós. Mudou, então, para O verão e as mulheres ${ }^{97}$. Parece ter havido aí um desejo de afastar uma concepção, digamos, mais científica, que evocasse talvez categorias geográficas, para substituí-la por outra, mais lírica.

Representativa das tensões entre cidade e natureza, a crônica "O Mato"98 suscita uma série de questões que surgem com frequência na produção de Rubem Braga. Vejamos como elas aparecem:

\section{O mato}

Veio o vento frio, e depois o temporal noturno, e depois da lenta chuva que passou toda a manhã caindo e ainda voltou algumas vezes durante o dia, a cidade entardeceu em brumas. Então o homem esqueceu o trabalho e as promissórias, esqueceu a condução e o telefone e o asfalto, e saiu andando lentamente por aquele morro coberto de um mato viçoso, perto de sua casa. O capim cheio de água molhava seu sapato e as pernas da calça; o mato escurecia sem vagalumes nem grilos.

Pôs a mão no tronco de uma árvore pequena, sacudiu um pouco, e recebeu nos cabelos e na cara as gotas de água como se fosse uma bênção. Ali perto mesmo a cidade murmurava, estalava com seus ruídos vespertinos, ranger de bondes, buzinar impaciente de carros, vozes indistintas; mas ele via apenas algumas árvores, um canto de mato, uma pedra escura. Ali perto, dentro de uma casa fechada, um telefone batia, silenciava, batia outra vez, interminável, paciente, melancólico. Alguém, com certeza já sem esperança, insistia em querer falar com alguém.

Por um instante, o homem voltou seu pensamento para a cidade e sua vida. Aquele telefone tocando em vão era um dos milhões de atos falhados da vida urbana. Pensou no desgaste nervoso dessa vida, nos desencontros, nas incertezas, no jogo de ambições e vaidades, na procura de amor e de importância, na caça ao dinheiro e aos prazeres. Ainda bem que de todas as grandes cidades do mundo o Rio é a única a permitir a evasão fácil para o mar e a floresta. Ele estava ali num desses limites entre a cidade dos homens e a natureza pura; ainda pensava em seus problemas urbanos - mas um camaleão correu de súbito, um passarinho piou triste em algum ramo, e o homem ficou atento àquela humilde vida animal e também à vida silenciosa e úmida das árvores, e à pedra escura, com sua pele de musgo e seu misterioso coração mineral.

\footnotetext{
96 "A cidade e a roça é, significativamente, o título de uma de suas coletâneas de crônicas e exprime os polos de atração do imaginário do autor, para quem eles nunca andam separados. É que essas histórias compõem um espaço amplo e mutável, uma espécie de geografia sensível, obediente aos desígnios da memória e da emoção, em cujos mapas uma pequena cidade da infância - Cachoeiro de Itapemirim - se gruda naturalmente aos grandes centros do vasto mundo." Cf. ARRIGUCCI JR., Davi. "Braga de novo por aqui", op. cit., p. 44.

${ }^{97}$ CARVALHO, Marco Antonio de. Rubem Braga: um cigano fazendeiro do ar. Rio de Janeiro: Globo, 2007, p. 391. O título mudou em 1986, quando da publicação da quarta edição do volume.

${ }^{98}$ BRAGA, Rubem. A traição das elegantes, op. cit., p. 17-19.
} 
E pouco a pouco ele foi sentindo uma paz naquele começo de escuridão, sentiu vontade de deitar e dormir entre a erva úmida, de se tornar um confuso ser vegetal, num grande sossego, farto de terra e de água; ficaria verde, emitiria raízes e folhas, seu tronco seria um tronco escuro, grosso, seus ramos formariam copa densa, e ele seria, sem angústia nem amor, sem desejo nem tristeza, forte, quieto, imóvel, feliz.

Logo na primeira oração, o cronista faz a descrição das mudanças do clima na passagem de um dia: descreve primeiro o temporal da noite, em seguida diz que choveu algumas vezes pela manhã e durante o dia e, enfim, que "a cidade entardeceu em brumas". A intenção parece ser a de sugerir a atmosfera tumultuada provocada pelas chuvas e de situar, ao final desse período, o clima ameno e algo evanescente em que "o homem", personagem da crônica, vai atuar.

É nessa tarde de neblina que ele abandona o trabalho e os problemas da vida urbana para adentrar o mato perto de sua casa. O viço e a umidade da vegetação remetem à chuva incessante do dia, que o homem havia observado na cidade. Já no mato, ele sacode uma árvore e recebe as gotas que caem "como uma bênção", antecipando o aspecto sagrado com que o cronista vai caracterizar a natureza, como veremos. Ao mesmo tempo em que observa os elementos da natureza em repouso, ele ouve ao longe os barulhos da cidade agitada, os quais, além de tudo, só produzem ruído e não estabelecem comunicação. São os atos falhados da vida urbana, que o cronista passa a enumerar.

No entanto, ele se compraz em perceber que esses problemas podem ser compensados por viver em uma cidade como o Rio de Janeiro, no limite "entre a cidade dos homens e a natureza pura". Enquanto pensa isso, ele vê um camaleão passar e volta sua atenção novamente para os elementos da natureza: a humilde vida animal, a vida "silenciosa e úmida das árvores", o "misterioso coração mineral" da "pedra escura". É curioso como o cronista atribui vida a esses elementos: não só a própria palavra vida é empregada duas vezes, para a esfera animal e vegetal, como uma inanimada pedra tem "pele de musgo" e "coração mineral".

Gradualmente, o homem volta a se ambientar na natureza e deseja fundir-se a ela, imaginando sua transformação num "ser vegetal", em etapas sequenciadas pela grande quantidade de vírgulas, estabelecendo uma cadência que segue numa diminuição progressiva do movimento até chegar à imobilidade final. 
Para avançar na interpretação, talvez seja interessante comparar a crônica editada em livro com a versão publicada, em 1952, no jornal Correio da Manhã 99 . Nesta primeira versão, há maior especificação dos problemas da vida urbana no terceiro parágrafo:

Por um instante, o homem voltou seu pensamento para a cidade e seus problemas - a cidade sem água, atravancada de bondes morosos, o edifício há três meses esperando gás, a Companhia prometendo telefone, mentindo, adiando, racionando, enriquecendo homens frios e distantes, corrompendo, tapeando, explorando com técnica, vozes macias de senhores bem empregados com secretárias gentilíssimas, diplomatas, militares, engenheiros, "boys" humildes ou importantes, contratos capciosos e inúteis. E por associação, começou a pensar no governo, os empregos, e inquéritos, e arranjos, e promessas - mas um camaleão...

Vemos que a referência aos problemas é mais explícita na primeira versão: a falta de água, o trânsito, a inapetência das companhias telefônicas, a corrupção e a exploração. A técnica da enumeração, empregada aqui, parece consistir em criar um clima abafadiço, de sufocamento, dando a ver a profusão de problemas urbanos na qual o homem está enredado.

$\mathrm{Na}$ versão definitiva, esses problemas estão mais atenuados, porque os termos empregados figuram aspectos gerais da vida moderna, sem maior especificação. O jogo de ambições e vaidades, a caça a dinheiro ou prazeres, a procura de amor e importância têm lugar ali como poderiam ter em qualquer outra cidade. A enumeração também é mais curta e cadenciada, com a interposição das conjunções aditivas, figurando mais uma lamentação resignada do que uma exposição de problemas. Essa disposição, por sua vez, confere maior equilíbrio ao ritmo da crônica, já que na enumeração dos elementos naturais, no último parágrafo, o andamento é também menos acelerado. A observação sobre o Rio de Janeiro, presente somente nesta versão e localizada praticamente na metade do texto, parece espelhar as duas faces da cidade: os problemas urbanos, na primeira parte, e as compensações oferecidas pela natureza, na seguinte. A publicação em revista semanal ilustrada, de leitura mais distendida do que a feita no jornal, também pode ter pesado para que houvesse essas alterações.

Na primeira versão, ao contrário, as mazelas da cidade são chamadas pelo nome. A falta de água, gás e telefone, o trânsito crescente e os serviços mal prestados são culpa de políticos, empresários, burocratas e mesmo de trabalhadores. Mediadas por contratos, arranjos, promessas e inquéritos, as relações corrompidas são parte dos problemas da

99 Ver a reprodução da crônica publicada no jornal no Arquivo Rubem Braga, disponível em <http://docvirt.com/DocReader.net/AcervoRubemBraga/9700>. Acesso em 20 de abril de 2018. A crônica foi republicada em seis outras ocasiões: no mesmo ano, em 1952, no jornal $A$ União, diário oficial do estado da Paraíba; na revista Manchete, em 1954 e 1963; no jornal O Globo, em 1961; no Diário de Notícias, em 1966; e na Revista Nacional, em 1982 , sob o título "O homem e a árvore". A busca no acervo foi feita pelo seguinte link <http://docvirt.com/DocReader.net/AcervoRubemBraga/15439?pesq=camaleão>. Acesso em 20 de abril de 2018. 
cidade. No contexto urbano, as ações se resumem a explorar, corromper, mentir, racionar, enriquecer os outros. A enumeração de sujeitos, meios e ações é acachapante.

Esse trecho da crônica parece descrever com exatidão as bruscas mudanças que o Rio de Janeiro vive naquele período. A ocupação intensiva de determinadas áreas da cidade, principalmente na Zona Sul, é incentivada pelo poder público, mas não é acompanhada pelo incremento da infraestrutura urbana. As fontes de emprego, ainda localizadas no centro, demandavam a melhoria dos transportes públicos e a renovação da estrutura viária, dado o aumento no número de veículos particulares. Por isso, construíramse nessa época túneis e vias expressas, mas que acabaram por beneficiar apenas a parcela mais abastada da população ${ }^{100}$.

Voltando à crônica, é compreensível também o fato de os problemas serem especificados nessa primeira publicação, de 1952. Como se sabe, Rubem Braga era notório opositor de Getúlio Vargas, presidente naquela época - daí talvez o desejo de sublinhar os problemas e enumerá-los com maior especificidade; há, inclusive, o emprego do termo "governo". Além disso, a referência aos diplomatas pode dar a entender que o cronista fala a partir da capital do país, transferida para Brasília somente em 1960. Na comparação, também se pode notar maior contundência na menção ao telefone: enquanto no texto de 1952 o cronista identifica a responsabilidade pelo problema, ao dizer que uma companhia promete (e não cumpre) a instalação da linha telefônica, na versão do livro o telefone tocando em vão é apenas um "ato falhado da vida urbana".

\footnotetext{
${ }^{100}$ Como nota Maurício de Almeida Abreu, o período compreendido entre os anos de 1946 e 1964 foi de penetração do capital estrangeiro e de intensificação do processo de substituição de importações - para produzir no país não só bens de consumo imediato, mas também bens de consumo duráveis e de capital. Entra em curso um processo inflacionário que reduz o salário real e valoriza o solo urbano. Não há entretanto uma política de uso do solo, e o programa de habitação popular não dá conta da grande demanda. Inicia-se uma crise habitacional generalizada, que mostra a necessidade de políticas de redistribuição de renda, dentre as quais a reforma urbana - que será abortada com o golpe de 1964 . O censo demográfico de 1960 mostra que mais da metade da população carioca era composta de migrantes com menos de dez anos de residência. Desse contingente, praticamente a metade foi para as periferias. Na zona sul, há ocupação intensiva do solo a partir de 1946, quando a prefeitura permite em Copacabana a construção de edifícios com oito, dez ou doze andares, conforme a localização. A partir dos anos 1950, o governo passa a aplicar a Lei da Usura, impedindo o reajuste de prestações e saldos devedores, e congela os aluguéis, que também desestimulavam a compra para renda. Contornouse isso com a construção por administração, que transferia os riscos da empreitada para o comprador. Mas a construção por administração, por si só, não garantia a continuidade das obras nem os lucros das empresas, como argumenta Maurício Abreu. A solução foi encontrada paradoxalmente na legislação, que não previa áreas mínimas nem formas. Começaram a se construir edifícios com quarto-sala e conjugados, e o lucro seria garantido pela quantidade de unidades vendidas. Copacabana, antes um bairro de renda alta, começou a ser ocupada pela classe média-baixa, e seu crescimento conteve o crescimento em outros bairros oceânicos e estimulou a mudança dos mais abastados para áreas menos acessíveis, como Leblon e Lagoa. O crescimento da zona sul demandou a renovação da infraestrutura física, pois as fontes de emprego continuavam a se localizar no centro, o que acentuou os problemas de deslocamento centro-zona sul, exigindo a melhoria tanto do transporte coletivo como das vias de circulação, já que também crescia o número de veículos particulares. Assim, a avenida Beira-Mar não conseguia mais dar vazão ao intenso tráfego e passou-se a construir uma série de túneis e vias expressas. Esse processo se intensifica a partir do prefeito Negrão de Lima, nomeado por JK, e permanece na administração seguinte e na posterior, de Carlos Lacerda, que continuou a construção de viadutos e novas avenidas. O objetivo, como é evidente, atendia apenas às classes altas, que dependiam do automóvel para circular. Como explica o autor, tratava-se de uma "ação parcial do poder público em benefício das classes de maior poder aquisitivo". ABREU, Maurício de Almeida. "O período 1950-1964", in Evolução urbana do Rio de Janeiro, 4ª ed., Rio de Janeiro: Instituto Pereira Passos, 2013, p. 115-135.
} 
Assim, a crônica parece ter sido alterada não só para afastar os dados referenciais, que poderiam revelar problemas circunscritos a lugar e período determinados, como também para adequá-la ao meio em que seria publicada, suavizando-a e deixando-a mais propícia a uma leitura de fim de semana. Ao adotar termos generalizantes, o cronista parece dizer que o Rio de Janeiro tem os mesmos problemas de qualquer outra cidade, mas é a única com escape para a natureza, o que a eleva a uma condição mítica ${ }^{101}$ (e, portanto, distante da cidade real, que a primeira versão pareceu privilegiar). Não à toa, será essa versão, publicada na revista Manchete, a escolhida para constar em livro.

Pode-se perceber, igualmente, uma notação de dimensão sagrada no que toca à natureza, ao passo que a cidade tem aspecto diabólico: a corrompida cidade dos homens murmura e estala com ruídos, ranger de bondes e vozes indistintas, enquanto a natureza pura, cuja água pode ser uma bênção, abriga a humilde vida animal, além da vida silenciosa das árvores e do misterioso coração mineral das pedras. É nesse lugar que o homem pode ficar em paz, num grande sossego, livre de sentimentos bons ou ruins. Ali ele pode se imaginar transformando-se num ser vegetal, quieto e imóvel, mas forte e feliz.

O que mudou da primeira publicação para a definitiva? Os problemas amainaram? Ao contrário, os problemas parecem ter se acirrado. Qual então o sentido da mudança?

Na primeira versão, podemos dizer que a enumeração de problemas específicos e concretos da cidade, em andamento acelerado, e o emprego de termos genéricos na natureza, em ritmo mais lento, geram certo desequilíbrio formal. Já na segunda versão, a inespecificidade dos termos, tanto dos elementos da cidade quanto da natureza, bem como a enumeração mais cadenciada nos dois âmbitos, possibilita um maior equilíbrio formal. Assim, na primeira versão a acuidade dos referentes urbanos acaba por revelar-se um desacerto formal, enquanto a generalidade dos termos é o garante da unidade formal na segunda versão.

Com relação ao foco narrativo, diferentemente da maioria das crônicas de Braga, esta apresenta um narrador em terceira pessoa, em que o personagem principal é um homem anônimo. O que poderia parecer uma estratégia para estabelecer distanciamento, porém, acaba por criar identificação: o homem da crônica pode ser qualquer cidadão que

\footnotetext{
${ }^{101}$ Ao comentar o livro Fala, Amendoeira!, de Carlos Drummond de Andrade, Antonio Candido define-o como "pequena mitologia portátil". Primeiro livro de crônicas, em sentido estrito, de Drummond, a mitologia seria, segundo o crítico, a operação de "encontrar um significado para essa revoada de pequenos traços do cotidiano". Esse significado, por sua vez, surgiria "da disposição de explicá-los por meio de uma espécie de princípio que os habita, diferente da sua aparência". CANDIDO, Antonio. "Dois cronistas". Textos de Intervenção. São Paulo, Duas Cidades; Ed. 34, 2002, p. 207. Em nosso caso, o cronista opera a mitificação do Rio de Janeiro pela marcação de sua singularidade e por características sagradas e misteriosas que ele imputa à natureza da cidade.
} 
lida com os problemas urbanos. O barulho infernal da cidade, que ganha vida própria (ela murmura, estala em ruídos e ranger de bondes, tem buzinas de carros e vozes indistintas), pode ter um escape no recesso da natureza, com o silêncio, a paz, o sossego e a fartura. Quando o homem volta seu pensamento para a sua vida na cidade, ficamos sabendo que o narrador é também onisciente, pois este sabe e descreve o que seu personagem pensa sobre os problemas urbanos. Ao comentar a configuração privilegiada do Rio de Janeiro, a intrusão opinativa faz com que o narrador passe também a se identificar com 0 personagem. Já no momento em que relata o desejo de fusão à natureza, o narrador sabe não somente o que o homem pensa, como também o que ele sente, aumentando a identificação entre os dois. O leitor, já identificado ao homem e seus problemas urbanos, e agora ao narrador, vai sendo engolfado pela narrativa. No último parágrafo, o leitor pode afinal também se imaginar, como o personagem, transformando-se num ser vegetal.

Um itinerário parecido é percorrido em outra crônica, "Da praia"102, narrada em primeira pessoa. A diferença é que, aqui, o espaço natural é a praia e o mar, e não o mato. Mas, do mesmo modo que na crônica anterior, o narrador está no espaço urbano (neste caso, num bar), avista o sol se pondo no mar e resolve sair para caminhar na praia. Seguese a descrição da paisagem, a comparação entre a vastidão do oceano e a pequenez do homem, lembranças de nado solitário e de passeios de canoa no mar. Igualmente, 0 cronista lembra a proximidade do espaço urbano e o aspecto singular da cidade em que vive, certamente remetendo ao Rio de Janeiro: "E ainda somos abençoados, porque vivemos nesta cidade perante o amplo mar". Entretanto, ao voltar para a cidade, o cronista lamenta o dia a dia citadino: "Estamos outra vez quadriculados em nosso tédio municipal". $\mathrm{Na}$ descrição sucinta dos problemas urbanos, também feita aqui, o cronista se refere novamente ao trânsito ("Estrondam bondes"), à população crescente ("A lenta maré humana começa a subir", "as filas se mexem inquietas"), à falta de água ("Ajoelhemos perante a torneira seca").

Em "Homenagem ao sr. Bezerra"103, o cronista reclama de um incorporador que cavou um buraco em frente a seu prédio para erguer um edifício. Ele argumenta, de modo irônico, que o objetivo do empreiteiro parece ter sido o de tirar-lhe a vista do mar, tema constante de suas crônicas, impedindo-o assim de escrever. Em seguida, o narrador relata que a obra está parada, os operários se foram e só restou o buraco. Por fim, o cronista deseja que o sr. Bezerra passe por dificuldades financeiras, entretendo "com fúteis

\footnotetext{
102 BRAGA, Rubem, Um pé de milho. 4ª ed. Rio de Janeiro: Ed. Record, 1982, p. 75-78.

103 BRAGA, Rubem, Ai de ti, Copacabana!., op. cit., p. 109-111.
} 
esperanças, anos a fio, o coração dos ex-futuros condôminos”104. O que o cronista parece descrever aqui é um sintoma do processo de especulação imobiliária ocorrendo na cidade, com prédios sendo construídos e degradando a paisagem natural, com a ocupação desordenada e a verticalização do bairro.

"Um sonho de simplicidade"105 é outra crônica em que o narrador transita entre a natureza e a cidade. A narrativa começa in media res, "no meio dessa desarrumação feroz da vida urbana", quando o cronista tem um "sonho de simplicidade" e começa a se questionar sobre sua vida mundana: o hábito de fumar, de beber uísque, frequentar o bar com amigos, saber intrigas. Certa vez, conta, teve um "ataque de pudor" ao se pegar escolhendo uma gravata, "pano colorido para amarrar ao pescoço"106. E reclama novamente a simplicidade para a vida: bastariam uma casa, comida, mulher, poder andar limpo e não sentir sede nem fome. O cronista passa a contar um episódio em que foi pescar com um caboclo do Acre: eles saem à noite, ficam cansados, vão até a choça de um seringueiro, acendem fogueira, comem peixe, tomam cachaça. Ele deseja então deixar a inquietação das "madrugadas urbanas" e começar uma "vida mais simples e sábia", baseada não no trabalho de homem de jornal, mas fazer algo de "sólido e singelo", de "útil e concreto".

O cronista também reclama do trabalho alienado que tem de exercer no contexto urbano. Assim, ele se queixa de ganhar a vida "nesse comércio de pequenas pilhas de palavras, esse ofício absurdo e vão de dizer coisas, dizer coisas...". Seu desejo está ligado a trabalhos manuais, "tirar areia do rio, cortar lenha, lavrar a terra", algo que cansasse seu corpo, "mas deixasse a alma sossegada e limpa". O cronista pressupõe que esse é um desejo de todos ("Todo mundo, com certeza, tem de repente um sonho assim") e, enquanto devaneia, o telefone toca. Ele tira, então, um lápis do bolso para anotar "um nome, um número...", mas volta a seu sonho, perguntando-se a finalidade de tomar nota. E conclui que apenas precisamos viver, "sem nome, nem número, fortes, doces, distraídos, bons, como os bois, a mangueira e o ribeirão". O cronista postula aqui, ainda uma vez, o

\footnotetext{
104 Ibid., p. 111.

${ }^{105}$ BRAGA, Rubem, A traição das elegantes, op. cit., p. 23-25.

${ }^{106}$ Em oposição à vida autêntica sonhada pelo cronista, a peça de vestuário parece representar a convenção dos papéis sociais. Gilda de Mello e Souza chama a atenção para a importância, em alguns trechos da obra de Machado de Assis, da descrição das roupas no mundo masculino. A estudiosa destaca uma passagem de Quincas Borba na qual o narrador afirma que "o principal característico do homem não são as feições, mas o vestuário". Comparando com trechos de outros dois contos do escritor, ela conclui que a vestimenta dos personagens masculinos cumpria um "papel civil, definidor de status e instaurador de uma identidade fictícia, mas pacificadora" ("Macedo, Alencar, Machado e as roupas". A ideia e 0 figurado. São Paulo: Duas Cidades; Ed. 34, 2005, p. 88). Pode-se acrescentar que, nesse trecho, a gravata pode servir como um índice, como a metonímia do homem sério, do burguês cuja vida é baseada em valores como "a impessoalidade, a precisão, a vida regular e metódica, certo distanciamento emotivo", que Franco Moretti, ao analisar a forma do romance oitocentista, englobará na noção de "seriedade" ("O século sério", in O Romance, vol. 1: A cultura do romance, Franco Moretti (org.), trad. Denise Bottman. São Paulo, Cosac Naify, 2009, p. 823-863).
} 
afastamento de elementos próprios a um estágio mais desenvolvido da civilização, como nome e número, e o regresso a um estado primitivo, identificando-se a elementos da natureza como plantas e animais, em cujos adjetivos se misturam qualificações físicas e morais, que reforçam essa identificação entre homem e mundo natural.

Em comentário sobre a crônica "O Mato", mas que também pode se estender a essas outras crônicas que opõem campo e cidade, Davi Arrigucci Jr. diz que se trata do

(...) homem buscando a fusão mítica com o mundo natural em pleno centro da metrópole, como se um passado ancestral aflorasse, com a esperança de uma felicidade primeva, eliminando a consciência e o desgarramento essencial, no miolo da vida moderna. Mas logo se vê que esta evasão momentânea é também fugaz e sitiada, funcionando como um ponto de fuga que só aprofunda a perspectiva do ser erradio no presente. $O$ cronista parece sempre tentado a franquear a fronteira entre "a cidade dos homens e a natureza pura". Por isso, o Rio de Janeiro, cidade que tanto ama e de que tanto fala, com seu convite à evasão fácil para o mar e a floresta", surge para ele como cidade eleita, onde até quem leva a vida mais dura tem seu instante de sonho: "bela, insensata e frívola". Uma cidade feminina e passageira também - equilíbrio instável sobre a fenda profunda. ${ }^{107}$

Como se pode ver, os polos natureza e cidade se alternam continuamente nessa análise, tanto um quanto o outro sendo abordados sem maior especificação. Assim, a natureza está subentendida nas expressões "passado ancestral", "felicidade primeva", "evasão momentânea", ao passo que a dimensão urbana pode ser vista em termos como "desgarramento essencial", "miolo da vida moderna", "ser erradio no presente", "equilíbrio instável". Seja dito que a própria crônica de Rubem Braga solicita esse tipo de leitura, afastando o dado referencial e privilegiando a adoção de termos mais generalistas para conferir autonomia estética ao gênero, como vimos anteriormente. Ao adotar esse método, o crítico procura não se afastar do texto das crônicas, buscando se posicionar rente aos termos com que elas são escritas. Arrigucci parece até mimetizar a técnica enumerativa do cronista, no emprego abundante das vírgulas.

Vejamos, por exemplo, como o crítico estabelece a conexão entre o tema da natureza, que viemos estudando, e o da casa, que analisaremos em breve. Para ele, a nostalgia da natureza não é "reação conservadora e moralista", refugiada num "artesanato estetizante", mas antes um "núcleo de resistência" formado pela mescla de moderno e antigo, no qual a nostalgia não é propriamente de um "passado rural", mas de um "centro inexistente", uma casa à qual não é possível retornar. Por esse motivo, segundo o crítico, a casa se torna também motivo "recorrente e simbólico" nas crônicas de Braga ${ }^{108}$.

\footnotetext{
${ }^{107}$ ARRIGUCCI JR., Davi, "Braga de novo por aqui", op. cit., p. 45.

108 lbid., p. 45-46.
} 
Voltando à crônica "O Mato", pudemos ver, na leitura comparada de duas versões dela, como Rubem Braga optou por uma disposição lírica de seus materiais, em desfavor de uma configuração que, por mais que acertada quanto a seus referentes, prejudicaria a unidade formal do escrito. Além disso, a progressiva caracterização do narrador (primeiro, distanciado; depois, onisciente) faz com que o leitor vá, ele também, se identificando gradualmente ao personagem - e essa identificação é favorecida na segunda versão, mais lírica, com a intrusão opinativa sobre o Rio de Janeiro. Ao final, é possível inferir que narrador e personagem são uma só e mesma pessoa, com quem o leitor já está completamente identificado. $\mathrm{O}$ desejo do homem de fusão à natureza acaba por ser o desejo de qualquer habitante das grandes cidades, apontando, como que em avesso, para a modernização e a urbanização problemáticas que vinham se desenhando no período.

\section{2 A casa e a rua}

Em "A casa"109, o cronista compara as casas modernas com a que ele deseja para morar. Desde o início, há expressões que estabelecem o diálogo íntimo com o leitor: o tom de conversa ("Outro dia..."), a locução pronominal inclusiva "a gente", a expressão "um amigo meu", o uso de diminutivo. Veja-se a crônica na íntegra:

\section{A casa}

Outro dia eu estava folheando uma revista de arquitetura. Como são bonitas essas casas modernas; o risco é ousado e às vezes lindo, as salas são claras, parecem jardins com teto, o arquiteto faz escultura em cimento armado e a gente vive dentro da escultura e da paisagem.

Um amigo meu quis reformar seu apartamento e chamou um arquiteto novo.

O rapaz disse: "vamos tirar esta parede e também aquela; você ficará com uma sala ampla e cheia de luz. Esta porta podemos arrancar; para que porta aqui? E esta outra parede vamos substituir por vidro; a casa ficará mais clara e mais alegre." E meu amigo tinha um ar feliz.

Eu estava bebendo a um canto, e fiquei em silêncio. Pensei nas casinhas que vira na revista e na reforma que meu amigo ia fazer em seu velho apartamento. E cheguei à conclusão de que estou velho mesmo.

Porque a casa que eu não tenho, eu a quero cercada de muros altos, e quero as paredes bem grossas e quero muitas paredes, e dentro da casa muitas portas com trincos e trancas; e um quarto bem escuro para esconder meus segredos e outro para esconder minha solidão.

Pode haver uma janela alta de onde eu veja o céu e o mar, mas deve haver um canto bem sossegado em que eu possa ficar sozinho, quieto, pensando minhas coisas, um canto sossegado onde um dia eu possa morrer.

A mocidade pode viver nessas alegres barracas de cimento, nós precisamos de sólidas fortalezas; a casa deve ser antes de tudo o asilo inviolável do cidadão

${ }^{109}$ BRAGA, Rubem, Ai de ti, Copacabana!, op. cit., p. 55-57. 
triste; onde ele possa bradar, sem medo nem vergonha, o nome de sua amada: Joana, JOANA! - certo de que ninguém ouvirá; casa é o lugar de andar nu de corpo e de alma, e sítio para falar sozinho.

Onde eu, que não sei desenhar, possa levar dias tentando traçar na parede o perfil de minha amada, sem que ninguém veja e sorria; onde eu, que não sei fazer versos, possa improvisar canções em alta voz para o meu amor; onde eu, que não tenho crença, possa rezar a divindades ocultas, que são apenas minhas.

Casa deve ser a preparação para o segredo maior do túmulo.

Rio, maio, 1957.

O tom dos primeiros parágrafos é coloquial e traz comentários sobre aspectos típicos de casas modernas. Num primeiro momento, o cronista fala sobre casas vistas numa revista de arquitetura; depois, acompanha a visita de um arquiteto ao apartamento de um amigo, que este pretende reformar. É possível perceber, neste início de crônica, uma notação em que se ressaltam a claridade, a abertura, a transparência - não só nas características descritas da arquitetura moderna, mas também nos movimentos do narrador: primeiro, em sua abordagem informal, depois na fala franca e decidida do arquiteto e, por fim, no ar feliz de seu amigo.

No passo seguinte, porém, o cronista se encontra recolhido a um canto, fechado em $\mathrm{si}$, refletindo sobre essas casas, e conclui que está velho. $\mathrm{O}$ tom passa a ser grave e elevado, e o relato arisco dá lugar a tonalidades líricas. Constituindo seu desejo pela falta, ele começa a caracterizar a casa que quer para si. A repetição dos verbos querer e esconder, além do substantivo paredes, o uso de termos que sugerem intensidade (alto, muito, bem), e mesmo a camada sonora dos vocábulos empregados, com o predomínio das oclusivas - tanto bilabiais (paredes e portas) quanto dentais (trincos e trancas) -, são procedimentos que visam à poetização da casa. Ao contrário dos períodos curtos dos trechos anteriores, de dicção clara e informal, essa longa oração parece ter sido talhada para reforçar a ideia de clausura, além de remeter a um tipo de construção antiga.

O cronista concede em seguida que haja uma janela com vista externa, e aqui as vogais abertas (em "alta", "céu" e "mar") voltam a remeter à claridade. No entanto, o tom vai ensombrecendo com a necessidade de haver também um canto sossegado (repetido na mesma oração) onde ele possa se isolar e, enfim, morrer. No plano sonoro, o movimento da oração é de deslizamento suave, com o predomínio das sibilantes "s" e " $z$ " e da vogal "i", até desembocar na locução verbal.

O balanceio novamente é introduzido, com as "alegres barracas de cimento" almejadas pela mocidade, mas pende novamente para a casa desejada pelo cronista - e agora também pelo leitor, incluído na necessidade comum: "nós precisamos de sólidas 
fortalezas". Em seguida, o desejo se alarga e passa a incluir os habitantes da cidade, na abrangente figura do "cidadão triste", que deve ter direito a um "asilo inviolável". A esse cidadão deve ainda ser facultada a possibilidade, sem que haja constrangimentos, de nesse espaço "bradar" pela "amada". A qualificação progressiva da casa ganha ainda mais duas expressões, que vão acumulando sentido: "lugar de andar nu de corpo e de alma" e "sítio para falar sozinho".

O eu volta à tona e se define, novamente, pela negação. O trecho eleva-se um tom acima, assim como o relato narrado é substituído pela descrição lírica. Em seguida, a caracterização passa a ser das atividades que se podem exercer nessa casa imaginada: é o lugar de praticar atividades inconfessáveis, como desenhar o perfil da amada, fazer versos e rezar a divindades ocultas. No parágrafo final, o cronista conclui numa sentença curta e taxativa: "Casa deve ser a preparação para o segredo maior do túmulo".

Em poucas linhas, o cronista descreve os traços de uma casa moderna: estão lá a integração entre paisagem natural e construção, a fusão de arquitetura e escultura, a utilização de materiais industriais como o cimento armado e o vidro. Com sua estrutura de vidro e aço, essas casas pressupunham o ideal da sociedade sem classes. Sua transparência quer dizer que nada ali é guardado, sua fluidez permite a livre circulação. Num ensaio em que retoma ideias do escritor Paul Scheerbart, Walter Benjamin diz que o vidro é "inimigo do mistério" e da "propriedade"110. Lembrando os interiores burgueses, o filósofo assinala que o ritual de hábitos do salão e a preservação dos vestígios sobre a terra poderiam ser eliminados pelo vidro de Scheerbart e pelo aço da Bauhaus. Benjamin concebe a casa como cápsula, no interior da qual o homem burguês busca preservar os "vestígios da vida privada na cidade grande". Como o desenvolvimento acelerado das grandes cidades dificulta a conservação dos indícios de sua existência, ele ao menos busca proteger os seus acessórios e objetos de consumo. Para tanto, concebe capas e estojos para a guarda desses objetos, e a própria casa pode ser entendida como um "estojo para o ser humano"111. Esse caráter sublinha a questão da propriedade, que parece muito presente na crônica "A casa", na qual grossas paredes, trincos e trancas ressaltam a habitação como "asilo inviolável".

No Brasil, o desenvolvimento da arquitetura parecia perder o chão histórico no pós64. Ponta de lança no mundo em meados do século passado, o cenário arquitetônico nacional, do qual Brasília era o maior símbolo, termina por descobrir que o racionalismo

110 BENJAMIN, Walter. "Experiência e pobreza”, Magia e técnica, arte e política. São Paulo: Brasiliense, 1994, p. 117-8

${ }^{111}$ Id. "Paris do Segundo Império - o flâneur". Charles Baudelaire - um lírico no auge do capitalismo, p. 43 
modernizante, por si só, não poderia abolir o antagonismo de classes. Um exemplo é Vilanova Artigas, que "apostou a fundo no funcionalismo dos arquitetos como metodologia para chegar a uma sociedade justa"112, mas, depois de ver a derrota histórica da esquerda com o golpe, admitiu ver seu passado como "uma espécie de fantasia". Artigas retomaria em seguida seu "racionalismo progressista dogmático", naquele momento já desligado da integração social, o que, no contexto da ditadura, tornava-se "uma posição complicada"113. Assim, o ideal da arquitetura moderna, aqui como no mundo, deu no seu contrário ${ }^{114}$.

De sensibilidade interiorana, valorizando mais o trabalho artesanal que o progressismo industrial, Braga opõe a esse modelo de casa - transparente, aberto e integrado - uma construção fechada, cheia de paredes, portas, trincos e trancas. Esse fechamento parece ser o do lírico que precisa se distanciar da vida social para mostrar o que há nela de negativo ${ }^{115}$. Como vimos demonstrando, os trechos em que a disposição lírica parece se acentuar são justamente aqueles em que o cronista se encontra nessa casa-fortaleza. Mas qual o significado dessa contraposição? Percepção do envelhecimento e da proximidade da morte? Oposição nostálgica ao progresso inevitável? Pressentimento do que viria? Talvez Braga intuísse que as bases sobre as quais se assentou a arquitetura moderna não encontravam plenas condições no país. Ou duvidasse que os pressupostos modernos da arquitetura, por si sós, pudessem abolir a sociedade antagônica ${ }^{116}$. Ou, quem sabe, sua posição de privilégio não permitia criar efetivo interesse na integração dos pobres, ainda que fosse solidário a eles.

Cremos que há um pouco disso tudo. Primeiro, há um evidente contraste entre novo e antigo - ao arquiteto novo que propõe aquele modelo para seu amigo, ele opõe o velho apartamento que passará por reforma. Por extensão, ou seja, por não ser afeito àquele tipo

\footnotetext{
112 Citado por Roberto Schwarz, "Um jovem arquiteto se explica”, Martinha versus Lucrécia, p. 224. O texto faz parte da arguição do trabalho de conclusão de curso de Pedro Fiori Arantes e foi incluído como posfácio no livro Arquitetura Nova (São Paulo: Ed. 34, 2002), baseado naquele trabalho.

113 Ibid., p. 225.

114 "A aposta nos desdobramentos positivos do desenvolvimento das forças produtivas (no sentido de um salto qualitativo, revolucionário) se fez, entretanto, em todo o mundo, e especialmente na periferia (veja-se também a capital do Punjab, Chandigarh, projetada por Le Corbusier no início dos anos 50), sob formas atrasadas de produção e mesmo tirando partido dessa condição" (ARANTES, Pedro Fiori. "O crítico e os arquitetos". Um crítico na periferia do capitalismo. São Paulo: Companhia das Letras, 2008, p. 245.

${ }^{115}$ Esse desejo de fechar-se do mundo e, ao mesmo tempo, de expor essa vontade a público, parece indicar uma queixa contra um estado de coisas que ao cronista parece hostil. Em certa medida, é o que Theodor Adorno observa nas relações entre lírica e sociedade. Veja-se o trecho: "Seu distanciamento da mera existência torna-se a medida do que há nesta de falso e ruim. Em protesto contra ela, o poema enuncia o sonho de um mundo em que essa situação poderia ser diferente. A idiossincrasia do espírito lírico contra a prepotência das coisas é uma forma de reação à coisificação do mundo, à dominação das mercadorias sobre os homens, que se propagou desde o inicio da Era Moderna e que, desde a Revolução Industrial, desdobrou-se em força dominante da vida". (ADORNO, Theodor W. "Palestra sobre lírica e sociedade", Notas de Literatura I. São Paulo: Ed. 34, 2003, p. 69.)

${ }^{116} \mathrm{~A}$ respeito dos desdobramentos da arquitetura moderna no Brasil, antes e depois de 1964, vejam-se os textos de Roberto Schwarz "Cultura e política, 1964-1969" (O pai de família e outros estudos, São Paulo: Companhia das Letras, 2008, p. 93-94), "Pelo prisma da arquitetura" (Sequências brasileiras: ensaios, São Paulo: Companhia das Letras, 1999, p. 244-251), "Saudação a Sérgio Ferro" e "Um jovem arquiteto se explica" (Martinha versus Lucrécia, São Paulo: Companhia das Letras, 2012, p. 215-222 e p. 223-231).
} 
de casa, o cronista conclui que ele próprio está velho. E postula um tipo de construção onde os elementos obstam a passagem: paredes grossas, muitas portas, trincas e trancas, ambientes escuros. Tudo, aí, é fechamento, obscuridade, obstáculo, morte.

Assim, as atividades que ele pratica nessa casa devem ser realizadas ao abrigo da luz do dia, onde ele possa exercitar livremente sua subjetividade. O que o define melhor é o que ele faz despojado das convenções sociais: o desenho, o exercício poético, a prática da espiritualidade. A autodeclarada inaptidão para tais tarefas ("não sei desenhar", "não sei fazer versos", "não tenho crença") não o impede todavia de exercê-las. Pelo contrário, parece ser esse desvencilhamento das obrigações socialmente impostas que 0 instam a exercer a sua livre individualidade. Porém, no limite, esse isolamento solitário leva à morte - o que parece ser o paradoxo dessa crônica: para fugir aos choques da metrópole, à existência mortificante da vida na cidade, o cronista propõe um tipo de casa na qual ele possa escapar do ritual de convenções e obrigações da rotina urbana, permitindo-Ihe assim explorar suas faculdades artísticas e espirituais, ainda que estas tenham sido tolhidas justamente pelo dia a dia citadino. Mas essas atividades mostram, acima de tudo, o impasse em que ele está inserido: fazer versos para a amada ou desenhar o seu perfil denotam a impossibilidade amorosa, e a reza designa o apelo ao mundo espiritual. Para o sujeito moderno, seja na casa ou na rua, não há saída possível.

Braga parece reforçar a imagem da casa como "couraça amplificada do eu" ou "escudo contra o tempo"117 em "Receita de casa"118. Nessa crônica, o narrador propõe que uma casa deve ter, antes de tudo, um porão, para servir como "cemitério de coisas" e funcionar como uma espécie de "subconsciente dos vivos". Mais convencional que a casa anterior, entretanto, esta deve ter também varanda, jardim e horta, "janela para todos os lados", sala de visitas - a qual, segundo o cronista, é negligenciada por "ideias exóticas" de "arquitetos modernos" -, elementos que sugerem uma abertura que a outra não poderia ter.

Em outros textos, Braga faz breves críticas ao funcionalismo da arquitetura moderna e se crê investido para tal, já que diz entender "alguma coisa de arquitetura urbana"119. Numa crônica em que faz o elogio do guarda-chuva, como algo que pouco mudou ao longo da história e entretanto permanece útil, ele, irônico, diz que o objeto "entrou calmamente pela era atômica, e olha com ternura a arquitetura e os móveis chamados funcionais"120. Em "Fim de semana na fazenda", estudada no primeiro capítulo, ele pensa numa casa com

\footnotetext{
117 ARRIGUCCI JR., Davi, "Braga de novo por aqui", op. cit., p. 46.

118 BRAGA, Rubem, Um pé de milho, op. cit., p. 116-118.

119 lbid., p. 116.

${ }^{120}$ BRAGA, Rubem, "Coisas antigas”, Ai de ti, Copacabana!, op. cit., p. 85.
} 
abrigo para andorinhas e faz um apelo: "Arquiteto, meu amigo arquiteto, nenhuma casa é funcional se não tiver lugar para a andorinha fazer seu ninho"121. Em um perfil do arquiteto Oscar Niemeyer, Braga diz com ironia que, à acusação de ser prioritariamente um plástico, "técnicos garantem que ele parte da função para a invenção plástica, e os homens práticos - industriais, etc. - acreditam"122.

Braga pensa a casa também como "base física para a saudade", como extensão de uma ordem natural das coisas. Quando criança, acreditava que ela fazia parte da história de uma família, "desde sempre e para sempre", e por isso lhe era inconcebível que alguém pudesse vender ou alugar a própria casa. Em sua infância, também Ihe era incompreensível que pudessem existir edifícios, e achava de fato difícil que viesse a morar em um deles ${ }^{123}$. Essa mesma contraposição da casa, como lugar de sentimentos e lembranças, à dos edifícios, como espaço de impessoalidade e frieza, é relatada numa crônica em que um incorporador demole "uma sólida casa revestida de pedras" e destrói o parque que a rodeava, cortando suas árvores, "inclusive um belo pé de magnólia e um casal de pinheiros" que formavam sua vista particular, embora o advogado tivesse lhe informado que não existe esse "direito de propriedade visual e sentimental"124.

Para Arrigucci Jr., a casa abriga o narrador do "descentramento presente", configurando-se como um "espaço mítico de um cosmo desejado", um "universo harmônico sonhado", embora "inacessível para um ser dividido e instável no curso do tempo"125. Decerto, o descentramento, a divisão e a instabilidade desse sujeito podem estar relacionados às transformações aceleradas do Rio de Janeiro em franca modernização, que especificamos anteriormente. A mudança abrupta da vida na província para o cotidiano das grandes cidades pode igualmente ter contribuído para essa desestabilização do indivíduo. De outro lado, a remissão à casa da infância ou à fazenda rural, presente em tantas de suas crônicas, também ajuda a construir esse universo mítico e harmonioso.

Seguindo uma pista do próprio Arrigucci Jr., talvez possamos enveredar por uma outra interpretação. A propósito da crônica "A casa", o crítico diz a certa altura de seu ensaio sobre Braga: "É certo que ela [a casa] às vezes ainda surge como uma espécie de couraça amplificada do $\mathrm{Eu}$, refúgio do sujeito solitário e túmulo antecipado (...)"126. Com efeito, lembremos que nesta crônica o narrador tece breves críticas ao modernismo arquitetônico

\footnotetext{
121 Id., "Fim de semana na fazenda", op. cit., p. 62.

122 Id., "Oscar, o arquiteto", Os segredos todos de Djanira \& outras crônicas sobre arte e artistas, op. cit., p. 10-11.

123 Id., "As Pitangueiras d'antanho", A traição das elegantes, op. cit., p. 76-78.

124 Id., "Homenagem ao sr. Bezerra", Ai de ti, Copacabana!, op. cit., p. 110.

125 ARRIGUCCI JR., Davi, "Braga de novo por aqui", p. 47.

126 lbid., p. 46.
} 
e propõe uma casa fechada, na qual ele poderá se afastar da agitação urbana e exercitar livremente atividades solitárias. Temos, aqui, o sujeito ensimesmado, reflexionante e meditativo, à maneira do indivíduo burguês europeu, que cultiva o amor romântico e a espiritualidade - embora ele mesmo se declare inapto para praticar tais atividades. Resta, portanto, aquela construção fechada ao narrador, desejoso de nela exercitar sua individualidade e, no mesmo passo, impossibilitado de fazê-lo.

A figuração de um sujeito reflexivo, que medita longamente, não parece combinar nem com o cronista pressionado pela publicação diária nem com a limitação do espaço disponível para seus escritos no jornal, e ainda menos com a do narrador cordial que estabelece conversa íntima com o leitor. Vemos agora como essas condições estão internalizadas no texto e como elas impedem a própria constituição do indivíduo, mortificado em seu modelo de túmulo. Assim, mais do que um espaço mítico e harmonioso, nessa crônica Braga parece pintar a imagem da casa como um retrato agudo e negativo dos caminhos da nossa modernização.

Mas esse cronista, mesmo com o avanço das transformações nas grandes cidades, que vê com ceticismo, ainda pode sentir prazer em estar na rua. Em "O homem e a cidade"127, ele sai de casa e descobre um prazer renovado ao andar pelas velhas ruas do centro do Rio de Janeiro, agora que não mais reside ali.

\section{O HOMEM E A CIDADE}

Agora, que não preciso mais ir à cidade todo dia, descubro um prazer novo em andar por essas velhas ruas do centro onde tanto vaguei outrora.

E pego um estranho dia de verão: há um alto nevoeiro aéreo sob o céu azul, mas o vento espanta alegremente as nuvens esgotadas de chover; o ar é fino, a luz é clara, a manhã é assanhada, com uma alegria de convalescente que pela primeira vez, depois de longa doença, sai a passear entre as árvores, o mar e as montanhas azuis.

Parece que estamos em maio ou setembro, num desses dias cambiantes e leves em que as folhas têm um brilho mais feliz. E sinto prazer em andar pela calçada larga da Rua do Passeio, em espiar as grandes vitrinas coloridas de presentes de Natal. (Não quero comprar nada, não preciso ganhar mais nada, não é verdade que recebi na minha porta a graça juvenil de uma rosa amarela?)

A calçada está cheia de gente, e é doce a gente se deixar ir andando à toa. $\mathrm{Na}$ Rua Senador Dantas vejo livros, camisas, aparelhos elétricos, discos, fuzis, submarinos, gravatas; e os cartazes dizem que tudo é muito barato e fácil de comprar, os cartazes me fazem ofertas especiais para levar agora e só começar a pagar em fevereiro... Muito obrigado, muito obrigado, mas não preciso de nada. Entretanto, gosto de ver essa fartura de coisas: fico parado numa porta de mercearia contemplando reluzentes goiabadas e frascos de vinho, bebidas e gulodices de toda a espécie que vieram de terras longes se oferecerem a mim.

${ }^{127}$ BRAGA, Rubem Braga, Ai de ti, Copacabana!, op. cit., p. 201-203. 
Mas de repente houve alguma coisa - a visão de um muro, o som de uma vitrola distante, algum rosto no meio da multidão? -, alguma coisa que me devolveu ao meu ser antigo. Sou um rapaz magro nesta mesma rua, sou o verdadeiro estudante de 1929 e talvez cruze numa esquina, sem conhecê-la ainda, aquela que há de ser a minha amada, e tire do bolso a minha carteirinha da Faculdade para ter direito ao abatimento no cinema. Mas logo, por um instante, sou o homem dramático e silencioso de 1938, e caminho carregado de angústia por essa calçada que, entretanto, é a mesma de hoje - há o vento palpitando nos vestidos coloridos de mulheres finas que sorriem com dentes muito brancos entre os lábios úmidos. $E$ vou andando, tomo um café, sinto uma grande ternura pela cidade grande onde outrora te amei tanto, tanto, oh! para sempre perdida Lenora.

Lenora... E me dá uma humildade entre o povo, completo o dinheiro da entrada de um menino que quer ir ao cinema, espero um bonde, ajudo uma senhora gorda a subir com seu embrulho, ela agradece e sorri, é cinquentona e pobre, mas seu sorriso é bom, ela e eu somos cidadãos da mesma cidade e antes de saltar ela me desejará boas entradas. Vem o condutor, tem cara de alemão e é gordo, mas ágil e paciente, todos pagam sua passagem na boa ordem civil e cordial. Um homem conduz uma gaiola dentro do bonde, todos querem ver o passarinho - é um pintassilgo, diz ele.

Quieto, vou repetindo sem voz, para mim mesmo, teu nome, Lenora perdida, para sempre perdida, mas tão viva, tão linda, batendo os saltos na calçada, andando de cabelos ao vento dentro da minha cidade e de minha saudade, Lenora.

Rio, janeiro, 1960.

Cremos ser interessante destacar três momentos dessa crônica. O primeiro é aquele em que o narrador sai à rua bem disposto e olha com ternura as vitrines e as mercadorias à venda. Apesar do colorido dos mostruários chamando sua atenção e dos cartazes por todos os lados oferecendo preços baixos e facilidades para pagar, ele recusa as ofertas, primeiro em pensamento, como dão a entender os parênteses: "(Não quero comprar nada, não preciso ganhar mais nada, não é verdade que recebi na minha porta a graça juvenil de uma rosa amarela?)". Depois, não se sabe se a recusa é dita ou apenas pensada: "Muito obrigado, muito obrigado, mas não preciso de nada". Em seguida, apesar da recusa, o cronista ressalva que gosta de observar a "fartura das coisas", principalmente de alimentos "que vieram de terras longes se oferecerem a mim", como que humanizando esses alimentos ao dotá-los de vontade própria.

Em seu ensaio "Paris do Segundo Império", no trecho sobre o flâneur, Walter Benjamin observa que, se a mercadoria tivesse alma, ela "seria a mais plena de empatia no reino das almas"128, pois busca se adequar a cada tipo de comprador. Assim o filósofo alemão interpreta o texto em prosa As Multidões, de Charles Baudelaire, para quem a mercadoria teria tanto mais encanto quanto mais a massa de fregueses se excitasse, e a multidão também tiraria seu efeito inebriante a partir do fetiche das mercadorias. Seguindo

\footnotetext{
${ }^{128}$ BENJAMIN, Walter. "Paris do Segundo Império - o flâneur", Charles Baudelaire: um lírico no auge do capitalismo, Obras escolhidas v. 3. 1를 edição. Tradução de José Martins Barbosa, Hemerson Alves Baptista. São Paulo: Brasiliense, 1989, p .52.
} 
essa interpretação, o sujeito anônimo imerso na multidão, ele próprio "bem poderia ser a mercadoria"129.

Na crônica, entretanto, não se trata de uma multidão caótica, mas de uma movimentação mais fluida, na "boa ordem civil e cordial", como diz o narrador a respeito dos passageiros do bonde. Nem se pode dizer que o cronista caminhante nutre total empatia pelas mercadorias, como fazem ver suas seguidas recusas às ofertas. Sua situação lembra a do flâneur baudelairiano em Paris, a qual "guarda ainda alguns traços dos velhos bons tempos"130.

Assim, se soa despropositado transpor a Paris do Segundo Império para o Rio de Janeiro do começo dos anos 1960, ao menos podemos ter em mente algumas características do tipo social do flâneur. Segundo Benjamin, ele é o pequeno-burguês que, ainda não totalmente submetido à dominação da ordem produtiva, como o proletário, pode prescindir da identificação com a mercadoria, ao modo do cronista que recusa a compra dos bens oferecidos a ele e segue caminhando.

Digamos que, àquela época, apesar da urbanização acelerada e da população crescente, o centro do Rio de Janeiro ainda permitia caminhadas tranquilas, onde se podia sentir "prazer em andar pela calçada larga da Rua do Passeio", onde era "doce a gente se deixar ir andando à toa" e se podia nutrir "uma grande ternura pela cidade grande".

Outro trecho da crônica que vale destacar é aquele em que o narrador se põe a ajudar as pessoas ao seu redor: depois que a caminhada desperta nele bons sentimentos, ele se lembra de sua amada Lenora, o que o faz se sentir humilde entre o povo. Como a construção sintática privilegia a coordenação, com o predomínio das aditivas, 0 encadeamento do raciocínio não fica tão explícito à primeira vista.

Voltando ao entrecho, o cronista então completa a entrada de cinema de um menino, ajuda uma senhora a entrar no bonde, observa o condutor do veículo. Os passageiros pagam sua passagem, como seria de se esperar, e todos querem ver um pintassilgo trazido por um homem - tudo transcorrendo, lembremos ainda uma vez, na "boa ordem civil e cordial".

A cooperação de todos com todos, o clima de participação democrática, a solidariedade entre os cidadãos, tudo faz imaginar uma grande comunidade, que pode passar do plano da cidade, figurado na crônica, para o âmbito maior da nação, se

\footnotetext{
129 lbid., p. 53.

130 BENJAMIN, Walter. "Sobre alguns temas em Baudelaire", Charles Baudelaire: um lírico no auge do capitalismo, op. cit., p. 121.
} 
considerarmos a difusão em todo o território nacional da revista onde a crônica foi publicada.

Essa atmosfera de comunhão, o cronista não só a imagina como também, e sobretudo, a protagoniza. Assim ocorre quando, num primeiro momento, ele ajuda o menino com a entrada do cinema, e a mulher, a subir no bonde. No entanto, já a essa mulher ele faz uma restrição ("é cinquentona e pobre, mas seu sorriso é bom"), assim como ao motorista do bonde ("tem cara de alemão e é gordo, mas ágil e paciente"), ressalvando as qualidades positivas de ambos. Depois de subir no bonde e de participar do ritual coletivo da cidade, o cronista agora apenas observa o congraçamento geral entre os passageiros.

Assim, nessa passagem, podemos dizer que há primeiro a participação efetiva do cronista com a ajuda ao menino, depois uma participação com ressalvas auxiliando a mulher, em seguida a observação positiva sobre o motorista e, finalmente, apenas a contemplação do movimento dos passageiros no bonde. Se o cronista imagina uma comunidade, ela não se dá sem ressalvas, ainda que breves e, digamos, sem intenção declarada, o que pode mostrar suas cisões ${ }^{131}$.

Seja dito ainda que, nessa comunidade, mal se distingue onde termina a esfera privada e onde começa o espaço público, já que os laços familistas e a participação cívica ocorrem simultaneamente (a ordem "civil e cordial"), num tempo em que se acreditava que as relações cordiais, vistas positivamente na perspectiva da época, poderiam amenizar ou corrigir a frieza e a brutalidade das relações capitalistas ${ }^{132}$. Repassando os trechos analisados da crônica, vimos que, em primeiro lugar, há um movimento de identificação com a mercadoria, mas com reticências, dada a posição social do cronista, que ainda conseguia se resguardar da brutalidade das relações produtivas. Depois, há um movimento de identificação com os habitantes da cidade, mas também ele com reservas, como se pode

\footnotetext{
131 Talvez seja razoável questionar: "como é possível imaginar como comunidade uma sociedade antagônica?”. Só mesmo na imaginação, como responde Paulo Arantes à própria formulação de sua pergunta, acrescentando que, nesse caso, trata-se de uma imaginação instituidora, ou seja, que é a ideia de nação imaginada por seus membros o que a institui, e não o contrário (ARANTES, Paulo Eduardo. "Nação e reflexão". Zero à esquerda. São Paulo: Conrad Editora, 2004, p. 84).

132 Uma das convicções firmadas no ciclo desenvolvimentista é a de que era preciso tirar a população de sua condição agrária e semicolonial e trazê-la para o universo da cidadania, da sociedade moderna e industrial. Com isso, a cultura tradicional se mistura à moderna e essa mescla pode servir tanto para fixar uma anedótica identidade nacional quanto para questionar o desenvolvimento econômico nos países centrais. Passado o ciclo, no entanto, o que se verá é que essa mescla está engrenada no curso mundial do capitalismo, em seu desenvolvimento desigual e combinado. Veja-se o comentário de Roberto Schwarz a esse respeito: “(...) essa mescla do tradicional e do moderno se prestava bem para emblema pitoresco da identidade nacional. Por outro lado, é certo que o ritmo e a sociabilidade tradicionais lançavam por sua vez uma luz crítica sobre as pautas do progresso econômico dito 'normal', criando a presunção de que nas condições brasileiras a sociedade moderna seria mais cordial e menos burguesa que noutras partes" (SCHWARZ, Roberto. "Fim de século". Sequências brasileiras. São Paulo: Companhia das Letras, 1999, p. 192).
} 
ver nos comentários que o cronista faz da mulher que ele ajuda no bonde e do motorista do veículo, e também no fato de passar de participante a observador.

Assim, é possível vislumbrar que essa comunidade - que o cronista imagina como sua família mas que não o é de fato, pois ele pode desimplicar-se dela quando convier -, essa comunidade de laços frágeis chama sua atenção apenas quando ele se lembra de sua amada. Tanto assim que, depois da descrição do ritual coletivo no bonde, o cronista recolhe-se em postura reflexiva e, "quieto", repete "sem voz" para si mesmo o nome de Lenora. Esta, por sua vez, embora "para sempre perdida", permanece "viva" e "linda" na memória do narrador, que a imagina andando na calçada com os cabelos ao vento, "dentro de minha cidade e de minha saudade"133.

O sentimento fraterno do cronista entre os habitantes da cidade, portanto, é ativado pela lembrança de sua amada, que ao final volta à sua memória depois de ele ter cumprido suas obrigações no ritual coletivo. Pode-se dizer, neste caso, que o amor individual termina por se sobrepor ao compromisso que o cronista parecia ensaiar na participação da vida coletiva na cidade.

\section{3. Memória e utopia}

Em "Às duas horas da tarde de domingo"134, o cronista relembra momentos passados com uma mulher.

\section{Às duas horas da tarde de domingo}

NO MEIO de muita aflição e tristeza houve um momento, lembras-te? Foi por acaso, foi de repente, foi roubado, e se alguém tivesse tido a mais leve suspeita então seria a ignomínia total. Mas houve um momento; e dentro desse momento houve silêncio e beleza.

Seria impossível descrever o ambiente, estranho a nós ambos; e não havia nem cantos de pássaro nem murmúrio de mar. Talvez um ruído de elevador, uma campainha tocando no interior de outro apartamento, o fragor de um bonde lá fora, sons de um rádio distante, vagas vozes - e, me lembro, havia um feixe de luz oblíquo dando no chão e na parte de baixo de uma porta, recordo vagamente a cor rósea da parede.

Serão lembranças verdadeiras? Como voltar àquele apartamento, reconstituir aquelas duas horas da tarde, lembrar a data, verificar a posição dos móveis e o ângulo de incidência do sol? Do chão ou da porta do banheiro - creio que do chão - ele iluminava teus olhos claros que me fitavam quietos. O edifício, eu sei qual é. Seria possível procurar aquele vago casal amigo que encontramos na praia aquele dia e perguntar qual o número do apartamento em que então moravam?

\footnotetext{
${ }^{133}$ A expressão parece ecoar os primeiros versos do poema "Quando eu morrer", de Mário de Andrade, incluído no volume Lira Paulistana: "Quando eu morrer quero ficar,/Não contem aos meus inimigos,/Sepultado em minha cidade,/Saudade." ANDRADE, Mário de. Poesias completas, São Paulo: Livraria Martins Editora, 1966, p. 300. Devo a indicação a Ivan Marques.

134 BRAGA, Rubem, A traição das elegantes, op. cit., p. 97-100.
} 
Conseguiríamos licença do atual morador ou quem sabe penetraríamos sorrateiramente no apartamento, e então a mulher daquele vago casal nos diria aqui era o quarto, aqui o armário, a cama, além ficava o espelho...

Ah, haveria menos rumor na rua naquele tempo; menos automóveis estariam passando lá fora; mas certamente nas mesmas duas da tarde de domingo, embora não haja mais bondes, haveria algum rádio ligado esperando o começo de algum jogo de futebol, e o sol entraria no mesmo ângulo pela mesma janela. Pesquisaríamos os móveis antigos, iríamos comprá-los onde estivessem hoje, decerto a antiga dona se lembra a quem os vendeu e como eram - não creio que ainda sejam seus. Lembro-me que eram móveis banais; nós os colocaríamos no mesmo lugar e disposição...

Houve um momento. Talvez a pintura da parede hoje seja diferente; creio que era rosa. Tua roupa de banho era preta, tinha alça, lembro as marcas das alças. Foi subitamente, havia várias pessoas juntas, faltou água na casa de alguém, telefonouse para dizer que não esperassem para o almoço, houve desencontros na praia, apareceu o casal - e então, por milagre, tudo o que era contra nós, as circunstâncias, os olhares, os horários, os esquemas da vida civil, as famílias com seus rádios, suas feijoadas dominicais, os encontros de esquina, as conveniências e os medos, tudo o que nos separava subitamente falhou, o casal desculpou-se e partiu, iam almoçar com a mãe dela, a empregada sumiu, eu tinha saído e por acaso tive de voltar - na verdade eu não poderia reconstituir os detalhes tediosos e vulgares; a lembrança que ficou é de um momento em que boiamos no bojo de uma nuvem, longe da cidade e do mundo, e todos os ruídos se distanciaram e se apagaram, ainda estavas toda salgada do mar, teus olhos me miravam quietos, sérios, teus olhos sempre de menina, teus cabelos molhados, teu grande corpo de um dourado pálido.

Houve um momento, aquele momento em que a carne se faz alma; e depois, muito depois, me disseste a mesma coisa que eu sentira, aquele momento suspenso no ar como uma flor, o estranho silêncio, sim, te lembras!

E depois as coisas banais em que a vida nos tornou, os caminhos complicados que cada um teve de fazer pela vida. Mas o pior não aconteceu. Nada, ninguém nos destruiu aquele momento, nem voz, nem porta batendo, nem telefone; o momento foi acaso e loucura, mas dentro dele houve um instante de serenidade pura e infinita beleza.

Ah, não me podes responder. Falo sozinho. Estás longe demais; e talvez tivesse de olhar duas vezes para reconhecer neste homem de cabelos brancos e de cara marcada pela vida aquele que fui um dia, o que te fez sofrer, e sofreu; mas quero que saibas que te vejo apenas como eras naquele momento, teu corpo ainda molhado do mar às duas horas da tarde; e milhares, milhões de relógios eternamente trabalhando contra nós nos bolsos, nos pulsos, nas paredes, todos cessaram de se mover porque naquele momento eras bela e pura como uma deusa e eras minha eternamente; eternamente. Naquele edifício daquela rua, naquele apartamento, entre aquelas paredes e aquele feixe de sol, eternamente. Além das nuvens, além dos mares, eternamente, às duas horas da tarde de domingo, eternamente.

A crônica tem essa mulher como interlocutora ("No meio de muita aflição e tristeza, houve um momento, lembras-te?"), e o narrador repete diversas vezes, como em estribilho, a expressão "houve um momento". As lembranças são vagas, e a certa altura ele questiona se são mesmo verdadeiras. A única recordação mais fiável é a de um "feixe de luz oblíquo" no chão que iluminava os olhos da mulher, que por sua vez fitavam-no quietos.

Veja-se em seguida os termos com que o cronista descreve a mulher: o corpo ainda molhado do mar, bela e pura como uma deusa, além das nuvens e além dos mares. A descrição afasta o realismo da passagem e constrói uma imagem etérea e idílica, quase uma cena primitiva e imemorial, um passado originário ao qual se deseja voltar. Assim, ao 
tempo cronológico e linear dos "esquemas da vida civil", o cronista opõe o instante significativo do encontro com a mulher, que suscitará imagens da natureza, esquema muito frequente em crônicas de Braga.

É interessante observar que, nessa rememoração, o cronista não consegue se lembrar com exatidão dos elementos da vida moderna que o circundam no momento em que se encontra sozinho com a mulher: a dúvida é colocada em termos como "talvez", "decerto" e "certamente"; o que teria acontecido é posto no futuro do pretérito, sucedem-se interrogações e suposições permeadas por conjunções alternativas e alguns eventos anteriores ao encontro são descritos sumariamente ("eu não poderia reconstituir os detalhes tediosos e vulgares").

A linguagem é elevada, destacando-se a conjugação na segunda pessoa do singular. As repetições são também constantes, principalmente de expressões que denotam o aspecto temporal - "houve um momento", "eternamente", "às duas da tarde de domingo". Podemos ver aí, portanto, uma das linhas de força de seus escritos: o eterno condensado num momento, que quase sempre remete a um passado, no qual se abole 0 tempo de relógios e calendários.

É o que também se observa, por exemplo, na crônica "Os amantes"135, na qual o narrador e sua amada se isolam do mundo "inimigo" num apartamento. Os dois ignoram as ligações com a vida exterior, como o telefone e a campainha, e, conforme passam os dias, os alimentos acabam (ambos vão "emagrecendo de felicidade"), o relógio para e resta somente uma "tênue claridade" que atravessa as janelas "sempre fechadas", compondo um mundo "sonâmbulo, irreal, fechado". Não há aqui, é verdade, um instante que irrompe remetendo ao passado. No entanto, a composição dessa atmosfera de sonho parece também abolir a concepção usual do tempo, que transcorre no ritmo próprio do casal, destoante da rotina da cidade, do tempo cronológico do mundo exterior.

Davi Arrigucci Jr. diz que essas epifanias remetem a uma tradição pós-simbolista, que Braga vai herdar principalmente de Manuel Bandeira. O crítico compara as visões do cronista ao alumbramento bandeiriano: em ambos, pesaria o "senso modernista do momento poético", que é tomado de luminosidade e acaba por "se converter em símbolo de uma experiência rica e complexa".

Em outro viés, talvez seja interessante recorrer a uma concepção benjaminiana do tempo para interpretar essas imagens. Como se sabe, o filósofo alemão concebe o tempo

135 BRAGA, Rubem, A borboleta amarela, Rio de Janeiro: José Olympio Ed., 1955, p. 279-283. 
de maneira sui generis: o "tempo homogêneo e vazio" da progressão cronológica poderia ser contraposto a um tempo-de-agora, isto é, o "surgimento do passado no presente"136. Para Jeanne Marie Gagnebin, essas concepções podem ser estendidas do âmbito da historiografia para o da narração ${ }^{137}$ e a irrupção do passado também pode marcar o instante do que começa a ser, do que está por vir ${ }^{138}$.

Vejamos como isso ocorre em outra crônica, "Visão"139. Desde o início, o narrador parece querer ganhar a adesão do leitor, com a segunda pessoa do plural inclusiva. No dia cinzento da cidade, no caminho da rotina diária, o habitante da cidade se equilibra a custo para manter constante sua vida, preso ao "medíocre equilíbrio", quando um acontecimento se dá. Em contraposição à irrupção do pretérito perfeito "aconteceu", embora ainda não se saiba exatamente o quê, a oração seguinte inicia já com o sujeito individualizado, com o pretérito imperfeito reforçando o aspecto durativo de sua caminhada. Nessa longa oração, disposta num único parágrafo, o cronista destaca alguns aspectos de sua situação antes do acontecimento, ainda implícito a essa altura: são sete segmentos, iniciados por travessão e pela recorrência da expressão "eu vinha", em que o narrador discorre sobre sentimentos aplacados, o anonimato e a integração no contexto urbano, a vida administrada do homem na cidade, a conformação sem lamúrias à rotina citadina.

Assim, o sujeito caminha pela cidade num dia cinzento, "dispõe de regular saúde", com "seus negócios sentimentais aplacados" e "bem disposto para as tarefas da rotina". Mas já viveu "noites de tormenta e madrugadas de seda", "com todos os nervos e com toda a alma", e agora é "um homem que faz parte de sua cidade", "um transeunte", "um elemento altamente banal, de paletó e gravata", que acerta seu relógio "pelo grande relógio da estrada de ferro central do meu país". Pode-se ver caracterizado aí o sujeito pequenoburguês, o indivíduo sério e anônimo que não demonstra ou desperta sentimentos, anestesiado pela rotina do sempre igual, regulando sua vida pelo ritmo geral da cidade.

Depois dessa longa descrição de uma caminhada pela cidade, o cronista abre um parágrafo para finalmente relatar o acontecimento que presenciou: a visão de uma "figura de mulher", parada no semáforo dentro de um carro, que retribui o olhar por um instante e se perde a um "arranco do carro, na confusão do tráfego da rua estreita e rápida"140.

\footnotetext{
${ }^{136}$ BENJAMIN, Walter. "Tese XIII" apud LÖWY, Michael. Walter Benjamin: Aviso de incêndio: uma leitura das teses "Sobre o conceito de história". São Paulo: Boitempo, 2005, p. 116.

137 GAGNEBIN, Jeanne Marie. "Walter Benjamin ou a história aberta", in BENJAMIN, Walter. Magia e técnica, arte e política, op. cit., p. 17.

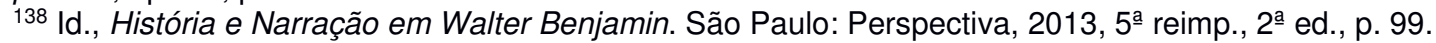

139 BRAGA, Rubem, A borboleta amarela, op. cit., p. 311-312.

140 E flagrante a semelhança da crônica com o soneto "A uma passante", de Charles Baudelaire: "A rua em torno era um frenético alarido./Toda de luto, alta e sutil, dor majestosa,/Uma mulher passou, com sua mão suntuosa/Erguendo e
} 
É interessante observar as imagens que tal visão suscita no cronista: trata-se de "uma paisagem úmida e brilhante de todos os sonhos de luz", "com vento agitando árvores e derrubando flores, e o mar cantando ao sol". A cidade é, portanto, o lugar em que o cronista se movimenta, embora ao final o que ele vislumbre sejam imagens da natureza. Assim, imerso no espaço urbano e nos seus ritmos, o cronista consegue reviver aquele sentimento de harmonia com uma espécie de paraíso, perdido e agora reencontrado. 0 acesso a essa visão edênica invariavelmente se dá por meio da mulher, considerada ainda parte do meio natural, como o provam outras crônicas como "O verão e as mulheres" e "Ao crepúsculo, a mulher". Desde o título, pode-se perceber a relação que o cronista faz entre as mulheres e os ritmos da natureza.

Assim, nas crônicas de Braga, a mulher está quase sempre relacionada à irrupção de um instante que torna o tempo eterno, mas também à remissão a um passado imemorial, simbolizado em imagens da natureza. Como contraponto, o cronista frequentemente faz a descrição do ambiente urbano, com sua rotina regulada pelo tempo dos relógios e dos calendários.

Todavia, para além de uma dimensão meramente nostálgica, de uma eventual "retomada salvadora do passado"141 em meio à deterioração da vida nas cidades, talvez o cronista sinta que essa experiência urbana, mesmo que degradada, deva ser transmitida. Um fato revelador do declínio da experiência foi, como observaram Benjamin e Adorno, o sofrimento das guerras, das quais os soldados retornavam mudos, incapazes de narrar o tempo passado no front ${ }^{142}$. Para Jeanne Marie Gagnebin, esse sofrimento "deveria ser

sacudindo a barra do vestido.//Pernas de estátua, era-lhe a imagem nobre e fina./Qual bizarro basbaque, afoito eu lhe bebia/No olhar, céu lívido onde aflora a ventania,/A doçura que envolve e o prazer que assassina.//Que luz... e a noite após! - Efêmera beldade/Cujos olhos me fazem nascer outra vez,/Não mais hei de te ver senão na eternidade?//Longe daqui! tarde demais! nunca talvez/Pois de ti já me fui, de mim tu já fugiste,/Tu que eu teria amado, ó tu que bem o viste!”. Walter Benjamin salienta nesse poema a experiência do habitante das metrópoles com a multidão, a qual comparece aqui como presença ausente. Para ele, trata-se de um amor "à última vista", "uma despedida para sempre, que coincide, no poema, com o momento do fascínio". São experiências desse tipo que o cronista também vai viver nas grandes cidades brasileiras em meados do século passado, com a diferença de que essas visões vão suscitar nele imagens da natureza. Talvez essa distinção se deva ao desenvolvimento tardio do capitalismo nos países periféricos, cuja passagem do rural para o urbano se deu de maneira mais abrupta do que nos países centrais. O poema traduzido, assim como a interpretação de Benjamin, está em BENJAMIN, Walter. "Sobre alguns temas em Baudelaire", op. cit., p. 117-118.

141 GAGNEBIN, Jeanne Marie, História e Narração em Walter Benjamin, op. cit., p. 62.

142 Talvez seja difícil medir o peso que a cobertura como repórter em duas guerras - a Revolução de 1932 e a Segunda Guerra Mundial, esta acompanhando os pracinhas da Força Expedicionária Brasileira (FEB) - teve nas crônicas de Rubem Braga. Mas é preciso ponderar que foram experiências decisivas, que sinalizam o sofrimento e a impossibilidade de comunicá-lo. Veja-se este trecho de crônica, escrita depois que o cronista volta do front mineiro, na Revolução de 1932: "Lá na frente eu ouvi muitas vozes, mas não eram humanas nem brasileiras. Falavam os Schneider, alemães, as Hotchkiss, francesas, as Colt, americanas, e os Z.B., belgas. Falavam na algaravia rude do ferro e do fogo. E cada palavra deles era um homem que tombava. O matraquear e o ribombo das máquinas da morte ecoavam nas serras e invadiam as matas de onde todos os pássaros haviam fugido. E eu não ouvi, nunca, a voz do Brasil. O Brasil está mudo, está morto." BRAGA, Rubem apud CARVALHO, Marco Antonio de, op. cit., p. 180. Ver também BENJAMIN, Walter, "O narrador", Magia e Técnica, Arte e Política, op. cit., p. 198, e ADORNO, Theodor W., "Posição do narrador no romance contemporâneo", Notas de Literatura I, 2003, p. 56. 
transmitido, deveria poder ser dito", mas de maneira diferente da do simples narrar ${ }^{143}$, pois passariam a exigir outra sintaxe ${ }^{144}$. Como afirma a estudiosa, o próprio Benjamin não aponta soluções para a questão, mas ela enxerga duas pistas deixadas por Benjamin no ensaio: a ligação entre morte e narração e a definição de conselho verdadeiro. Vamos nos deter nesta última. Gagnebin destaca o seguinte trecho do ensaio de Benjamin:

O conselho de fato é menos resposta a uma pergunta do que uma proposta que diz respeito à continuidade de uma história que se desenvolve agora. Para recebê-lo seria necessário, primeiro que tudo, saber narrá-la. (Sem levar em conta que uma pessoa só se abre a um conselho na medida em que verbaliza sua situação. $)^{145}$.

Assim, nessa interpretação, o conselho precisa ser colocado em palavras, mas não de forma "definitiva ou exaustiva"146, e sim "com as hesitações, as tentativas, até as angústias"147 da história, o que resultaria em "vários desenvolvimentos possíveis, várias sequências diferentes, várias conclusões desconhecidas"148, ajudando assim a escolher ou até a inventar a transformação dessa narrativa a princípio solitária, agora coletiva.

Na crônica "Homem no Mar"149, por exemplo, o conselho parece assumir os aspectos anteriormente descritos. Já em seu início, o narrador estabelece seu ponto de vista, o lugar de onde fala e observa: a varanda de seu apartamento. Na primeira oração, elementos do mundo urbano alternam com os do mundo natural: entre a varanda de um edifício moderno e o mar da paisagem, o olhar é interposto tanto por árvores como por telhados. Esse olhar se fixa, então, na praia, que está deserta e brilha sob a luz do sol. Um vento sopra e levanta pequenas espumas, que, filtradas pelo olhar terno do narrador, transfiguram-se em bichos alegres e humildes, para em seguida se desfazer. A virgulação faz que a leitura tenha muitas pausas, construindo um ritmo cadenciado, moroso, correspondente ao caráter quase inerte da paisagem.

A paisagem estática, no entanto, é quebrada pelo movimento de um homem nadando. O nadador imprime um ritmo vigoroso à sua atividade, que realiza com distância da costa, denotando maior integração à natureza. Essa impressão de harmonia com o meio natural é reforçada ainda pela direção do nado, "a favor das águas e do vento". O cronista observa então que as espumas parecem se movimentar mais rápido que o nadador e faz um raciocínio, cuja dimensão lógica se contrapõe ao tom descritivo do trecho anterior: como

\footnotetext{
143 GAGNEBIN, Jeanne Marie, História e Narração em Walter Benjamin, op. cit., p. 63.

144 Ibid., p. 63. Grifo da autora.

145 BENJAMIN, Walter apud GAGNEBIN, Jeanne Marie, História e Narração em Walter Benjamin, op. cit., p. 63.

146 GAGNEBIN, Jeanne Marie, História e Narração em Walter Benjamin, op. cit., p. 63.

147 Ibid., p. 63.

148 lbid., p. 63.

149 BRAGA, Rubem, A cidade e a roça, Rio de Janeiro: Ed. José Olympio, 1957, p. 15-17.
} 
espumas são feitas de água, vento e luz, e homens, de carne, ossos e coração, é justo que as primeiras se desloquem com mais rapidez.

O cronista reitera a materialidade do nadador e o ritmo de sua atividade. A admiração pelo homem vai num crescendo, reputando a ele atributos que enaltecem seu exercício: a nobreza calma, o esforço solitário e a bela missão são qualificativos que fazem crescer a empatia do narrador pelo homem. Em seguida, o narrador passa a descrever o trajeto e acompanha de perto cada movimento do nadador. Seu desejo é que esse ritmo permaneça constante: ele vê a necessidade de conservar a mesma batida de braçada; o nadador deve desaparecer assim como apareceu, e seguir no mesmo rumo. Essa constância é figurada ainda na virgulação do trecho, que achamos interessante transcrever para dar ideia do andamento:

Que ele nade bem esses cinquenta ou sessenta metros; isto me parece importante; é preciso que conserve a mesma batida de sua braçada, e que eu o veja desaparecer assim como o vi aparecer, no mesmo rumo, no mesmo ritmo, forte, lento, sereno ${ }^{150}$.

Trata-se de dois anônimos, um desconhecendo o outro, mas o narrador-observador espera que o sentimento de solidariedade que nutre pelo homem no mar seja recíproco. $O$ cronista recapitula o episódio, pensando no que viu. A atividade ganha contornos morais: requer responsabilidade, há um senso de dever e uma grandeza nessa tarefa, que ao observador cabe apenas admirar. Destaca-se paradoxalmente a gratuidade do gesto do nadador: este não implica tomada de posição nem a construção de algo útil. $O$ narrador constata apenas que se trata de uma coisa bela, realizada de maneira pura e viril.

No entanto, apesar da admiração, o cronista não consegue mais se aproximar do nadador. O que ele pode fazer é contemplá-lo, apoiá-lo em sua própria consciência, sem sair de si. Os homens já estão apartados uns dos outros, não se espera mais uma solidariedade concreta.

Porém, ao final, pode-se vislumbrar um movimento de estreitamento dos afetos. Assim, não só a empatia pelo nadador vai crescendo, como também a maneira pela qual o cronista passa a considerá-lo: de "silencioso apoio", o nadador ganha a "atenção" do observador e, por fim, sua "estima". Do mesmo modo, pelo procedimento da gradação, o homem no mar passa de "desconhecido" a "nobre animal" e "homem", para se tornar afinal um "correto irmão" na comunidade dos homens.

150 lbid., p. 16. 
Se o que o cronista admira no nadador são a austeridade, a determinação, a constância, o vigor e a virilidade, podemos supor que essas são características que ele próprio não possui. Ao contrário, ele é o sujeito que apenas observa e admira, que pondera e faz raciocínios lógicos, que não alcança o sentido daquela atividade; é, portanto, o homem citadino que rememora aquela antiga harmonia com a natureza, de que o homem no mar é portador. Assim, a empatia do observador da varanda pelo homem no mar cresce progressivamente, até que aquele possa nutrir por este sua mais alta estima, considerandoo inclusive um correto irmão. Num tempo em que o país passava por transformações rápidas e profundas, que promoviam um entusiasmo geral na crença da integração nacional e, simultaneamente, esgarçavam mais ainda relações sociais já dilaceradas, o cronista apostava numa solidariedade entre os indivíduos talvez recuperável.

No entanto, em nenhum momento há um conselho taxativo do cronista. Seu raciocínio ondulante parece seguir o ritmo do nadador e ele apenas admira a beleza da atividade do homem que vê de sua varanda. A certa altura, ele próprio diz: "Não consigo saber em que reside, para mim, a grandeza de sua tarefa". Aqui podemos vislumbrar a hesitação do conselho benjaminiano, isto é, o sentido do episódio que descreve parece ficar em aberto, como que instando o leitor a completar o quadro ${ }^{151}$. Arriscando uma interpretação, o que parece descrito aí é a solidão dos três polos que compõem a crônica: do nadador, do cronista e do leitor ${ }^{152}$. Embora saiba da separação entre eles, que a modernização acelerada Ihes impôs, o cronista faz acender a imaginação de uma comunidade baseada no aprendizado da sensibilidade.

Assim, nas visões desse cronista, lembranças de um passado idealizado irrompem no presente rebaixado da cidade. São imagens não raro suscitadas por mulheres, ou pela visão de mulheres, e que vão frequentemente evocar elementos da natureza. Esses instantes rompem com o tempo linear e cronológico e evocam um passado impreciso, lembranças de algo que não se sabe se efetivamente ocorreu, sendo antes a mistura de sensações e memórias. Essa quebra do tempo, mais do que recuperar esse passado, vai

\footnotetext{
${ }^{151}$ Arrigucci reitera a sabedoria do narrador das crônicas de Braga, destacando o caráter pragmático, a linhagem rural, a tendência à expressão proverbial e irônica, mas, ao mesmo tempo, o desajuste e o acanhamento de um "conselheiro tímido" diante das transformações aceleradas que a cidade grande lhe impõe. ARRIGUCCI JR., Davi. "Braga de novo por aqui", op. cit., p. 45.

152 "Benjamin deixou escapar - se Benedict Anderson esbarrou numa pista verdadeira - um traço notável do capitalismo editorial - sempre segundo nosso Autor -, o fato de que o livro foi a primeira mercadoria industrial produzida em série no estilo moderno e que, assim sendo, 'o jornal não passa de uma forma extrema do livro, um livro vendido em escala imensa, porém de popularidade efêmera. Poderia dizer-se que são best-sellers por um só dia. Daí a conclusão oposta - o paradoxo do leitor solitário, que se reproduz e resolve analogamente na cerimônia de massa do consumo diário do jornal e no isolamento absoluto em que o leitor avidamente se apropria do sentido de um romance: como vimos, e não custa repetir para melhor frisar a inversão da perspectiva, a leitura de um romance se desenrola bem no fundo da cabeça, em silenciosa intimidade, e, no entanto, cada leitor não seria senão a comunidade de leitores 'solitários' que, por assim dizer, leem por sobre seus ombros." ARANTES, Paulo, "Nação e reflexão", Zero à esquerda, 2004, p. 98-99.
} 
possibilitar a projeção utópica de um futuro que o cronista também não sabe precisar bem, mas que pressupõe uma existência comum, baseada na solidariedade.

Entre o fim dos anos 1950 e o início dos 1960, algumas crônicas de Braga passam a ser povoadas por esses instantâneos líricos, tornam-se essencialmente poéticas e fazem o gênero ganhar autonomia literária. Talvez o cronista tenha entrevisto ali, naquele período histórico específico, a possibilidade de uma sociedade integrada, de solidariedade entre os homens, mesmo numa rotina urbana já esgarçada pelos avanços modernos. Em conselhos hesitantes, Braga sugere modos de vida que remetem a um passado, mas que, longe de serem meramente nostálgicos, apontam para um futuro harmonioso, uma utopia que parecia perto de se concretizar na época. No entanto, mesmo um cronista solidário aos mais pobres já se deparava com impasses e dilemas que dificultavam a transposição das barreiras de classe, o que impedia a integração efetiva da sociedade brasileira. São impasses que só vão se aprofundar depois do golpe de1964. É o que veremos nos capítulos seguintes. 


\section{Uma questão de classe}

\subsection{Cronistas entre si}

\section{Em "O poema que não foi aprovado"153, Rubem Braga conta a história de um poema} escrito por lixeiros, que pedem a publicação na coluna do escritor.

\section{O poema que não foi aprovado}

Antigamente eu tinha aqui na Manchete, ao lado de minha crônica, uma pequena seção chamada A Poesia É Necessária. Ali eu publicava toda semana um poema, quase sempre de autor novo. Depois houve mudança na direção da revista e fui informado de que a poesia não era mais necessária.

Não discuto com a direção. A prova de que a poesia não é necessária é que a revista continua crescendo, vende como pão quente, está cheia de anúncios e rendendo bela erva.

Na verdade aquela seção me fazia viver com eternos remorsos, pois recebia diariamente cartas com poemas e livros de versos de gente do Brasil inteiro (e até de Portugal e Algarve) que queria aparecer em Manchete. Como não podia publicar mais de um poema por semana, eu desgostava a muito mais gente do que agradava. Dez vezes, vinte vezes mais. Além disso, não respondia às cartas dos leitores-poetas, o que naturalmente só fazia aumentar minha sólida fama de sujeito antipático, maleducado, metido a importante, "meio besta", etc.

Ah, que todos me perdoem, todos os poetas impublicados e todos os missivistas não respondidos. A eles dedico o pior poema que fiz em minha vida, e foi quando segui para a Itália como correspondente de guerra: "O pobre correspondente não era correspondido."

É tempo de Natal, sejamos todos amigos: perdoemo-nos as nossas más palavras e nossos maus versos.

Mas os poetas continuam a procurar-me. E desta vez a direção da revista que tenha paciência, vou publicar um poema. Este veio num cartão com o desenho de um sininho badalando.
"Aqui está nosso cartão
Em prova de amizade
Desejando-Ihe Boas Festas
Saúde e Felicidade.
Entra ano e sai ano
Trabalhando sem cessar.
São os fiéis Lixeiros
Que vêm vos cumprimentar.
Mais um ano de trabalho
Aqui estão quem vos prestou
Apesar de bem cansados
Às vossas ordens estou.
Os vossos Lixeiros
Artur, Emílio e Agenor."

Fiquei comovido, e dei 50 cruzeiros aos poetas. Foi pouco, é verdade. Mas a caixa estava fraca, nesse dia.

O pior é que o fim do ano está chegando e ainda virão outros poetas: o da tinturaria, o da padaria, o carteiro, etc. Preciso atender a todos esses poetas meus irmãos, e a caixa continua fraca. Além disso, como enfrentar essas Festas com o bar vazio, só com um restinho de Vovó Extra que um amigo me trouxe de Fortaleza? Ah, aqui outrora retumbaram uísques...

\footnotetext{
${ }^{153}$ BRAGA, Rubem, Ai de ti, Copacabana!, op. cit., p. 91-94.
} 
Tive uma ideia: telefonar para Henrique Pongetti e Fernando Sabino e propor mandar imprimir uns cartões com versos para nossos leitores. Pensei no Leon Eliachar também, mas se ele entrasse na coisa o público poderia pensar que era piada.

Redigi uns versinhos, sujeitos a críticas e sugestões, e li pelo telefone aos dois colegas. Até que os versinhos não estão maus, embora talvez um pouco baseados na lira de nossos fiéis lixeiros:

\author{
Entra ano e sai ano \\ Escrevendo sem cessar \\ São os vossos fiéis Cronistas \\ Que vêm vos cumprimentar \\ Feliz Natal e Ano Novo! \\ Se o uísque estiver sobrando \\ Lembrai-vos destes Cronistas \\ Que de sede estão penando: \\ Henrique, Rubem e Fernando.
}

Para minha grande surpresa os dois colegas repeliram com indignação minha ideia. Disseram que não ficava bem. Argumentei que não é justo que o padeiro ganhe festas e o cronista, afinal de contas um padeiro espiritual, não possa nem pedir. Repeliram-me em nome dos bons princípios, da boa ética - e, desconfio, um pouco também de seus maus fígados.

De qualquer maneira, para fazer a coisa sozinho eu fico sem jeito. Desisto da ideia - embora, naturalmente, eu seja incapaz de fazer uma desfeita se alguém, apesar disso, insistir em mandar uísque para a casa de um cronista pobre sim, mas soberbo, nunca!

Rio, dezembro, 1957.

Comparecem aí o humor ingênuo, contrapondo a poesia ao ganho comercial; o gesto voluntarioso, com a publicação do poema dos lixeiros sem anuência da direção. A crônica também revela dimensões variadas do ofício do autor: a relação com o público leitor, com o qual entabula uma espécie de conversa; a relação com seus pares, mas também com as classes baixas; a precariedade do trabalho jornalístico, sob ritmo industrial.

O pastiche do poema também ironiza a criação poética em contexto rebaixado, no limite um cinismo, se vistas as coisas a partir do nome do espaço "a poesia é necessária" (mas para quê?). A poesia é assim concebida de um ponto de vista utilitário, para ganhar visibilidade ou pedir bebida.

Esses aspectos - a atmosfera de cumplicidade com o leitor e, ao mesmo tempo, a desfaçatez com que trata os trabalhadores - permitem configurar principalmente o lugar social dos cronistas, pertencentes a uma camada privilegiada, que vai reverberar na forma das crônicas. Assim, é possível perceber um certo democratismo na relação com os de baixo, na atmosfera familista com que o cronista os representa e na compreensão da situação precária dos estratos mais baixos. Por outro lado, são aspectos que podem também ser vistos como condescendência e paternalismo. 
Há desnível entre o pedido de publicação de um poema e o pedido de uísque, assim como há diferenças entre o trabalho incessante dos lixeiros e o dos escritores-jornalistas. Há um certo estranhamento também na gorjeta dada aos lixeiros, sem que estes tenham pedido. Parece ser apenas pretexto para o cronista se queixar do pouco dinheiro e fazer o seu próprio pedido. Assim, mesmo que o cronista tenha de passar o ano inteiro "escrevendo sem cessar", como está escrito na paródia do poema dos lixeiros, sua posição ainda é superior à daqueles a quem ele pretende se igualar - isto é, os lixeiros, o tintureiro, o carteiro e o padeiro.

Sobre este último, ele ainda faz uma comparação, ao afirmar que o cronista é uma espécie de padeiro espiritual, o que diz muito: pretendendo se igualar a quem faz pães, ele acaba afastando-o, com a aposição do qualificativo espiritual.

Em outra crônica, na qual a figura do padeiro também aparece, Braga esclarece melhor a comparação desse ofício ao do jornalista ${ }^{154}$. Nela, o cronista diz ter aprendido a "lição de humildade" de um padeiro, que, para não incomodar, deixava o pão à porta do apartamento, tocava a campainha e dizia: "Não é ninguém, é o padeiro!".

Ele passa a comparar os ofícios: tanto o repórter quanto o padeiro fazem o trabalho noturno, assim como o pão saído do forno pode ser comparado ao jornal saindo da rotativa. Rapaz naquele tempo, o cronista se envaidecia quando saía seu nome no jornal, mas passa a sopesar sua importância a partir do episódio vivido, em que ficam patentes o anonimato e a invisibilidade do padeiro, agora assumidos também pelo escritor.

Mas a representação dos pobres é um assunto que abordaremos mais à frente. Por ora, vejamos como o ethos de grupo - e, num sentido mais abrangente, de classe - se configura na crônica de um outro escritor.

Em "O estranho ofício de escrever"155, Fernando Sabino conta da troca de crônicas que costumava ocorrer entre os colegas de ofício. "Condenados à crônica diária" - escreve Sabino -, ele, Paulo Mendes Campos e Rubem Braga às vezes tinham uma ideia na mesa do bar que servia de tema para os três. Até chegar o dia em que Braga "perde a cerimônia" e pede a Sabino uma crônica emprestada. Este encontra em seus guardados uma relatando a história de um menino que the pede um cruzeiro para uma sopa. Desconfiado do preço cobrado, o cronista o segue até a casa de pasto e confirma que existia mesmo uma sopa a

\footnotetext{
154 BRAGA, Rubem. "O padeiro", Ai de ti, Copacabana!, op. cit., p. 43-45.

${ }^{155}$ SABINO, Fernando. A falta que ela me faz. 16ª ed. Rio de Janeiro: Record, 1980, p. 20-22.
} 
esse preço. Rubem Braga substitui algumas palavras e republica a crônica sob outro título. Em outra ocasião, Sabino recorre a Braga, que lhe devolve a mesma crônica, alegando que as outras estão "muito gastas". Sabino ajeita, remenda e atualiza o escrito, e o intitula então "Esta sopa vai acabar".

Tanto na crônica sobre os poemas quanto na que fala sobre a sopa, é interessante a coincidência na autocaracterização dos cronistas: os dois afirmam serem "pobres", mas não "soberbos". Ou seja, o uso de termos parecidos faz pensar que algumas crônicas adquirem verdadeira feição de fórmula, disponível para uso geral dos cronistas ${ }^{156}$.

Não só os termos eram parecidos. Há crônicas em que anedotas inteiras são semelhantes, o que torna difícil saber a autoria original. Em "Minhas empregadas", de Paulo Mendes Campos, que analisaremos no capítulo seguinte, o cronista faz referência a uma doméstica que chegara atrasada porque o temporal havia carregado sua casa e seus pertences, mas ela se consola porque "é tão bom para a lavoura". É uma anedota semelhante à contada por Rubem Braga em "Justiça seja feita"157, de O homem rouco, na qual o cronista, ao falar das chuvas que fazem crescer as árvores, conta que ouviu da lavadeira Sebastiana que ela "quase não pôde dormir com a chuva e o vento frio entrando em casa". No entanto, diz o narrador, "essa velha da zona da Mata" se resigna com tudo e diz que "isso é bom para a lavoura". Em "O chamado Brasil brasileiro"158, de Recado de Primavera, Braga repete a história e insiste na expressão "é bom para a lavoura", concluindo que, na roça, trata-se de uma maneira de dizer, de pensar, de sentir.

É possível ver nesse conjunto de crônicas, também, a explicitação das condições de trabalho, nas quais a produção em série de escritos criativos pressiona os autores a se ajudarem uns aos outros, a repetir anedotas contadas entre si, ainda quando isso implique a reprodução de crônicas antigas ${ }^{159}$. Pode-se mesmo afirmar que há pouco constrangimento na confissão de culpa dos escritores, que chamam o leitor a, de certo modo, participar do conluio. Cúmplice do inocente delito, o público-leitor fecha o circuito

\footnotetext{
${ }^{156}$ Ver nota 22, p. 8

157 BRAGA, Rubem. O homem rouco. 2ª ed., Rio de Janeiro: Ed. do Autor, 1963, p. 23-25.

158 Id., Recado de primavera. 4ª ed. Rio de Janeiro: Record, 1986, p. 67-70.

159 Fernando Sabino, Paulo Mendes Campos, Otto Lara Resende e Hélio Pellegrino eram amigos desde a adolescência, dos tempos em que ainda moravam em Minas Gerais. Eles mantiveram a amizade quando se mudaram, todos, para 0 Rio de Janeiro. Os "quatro cavaleiros de um íntimo apocalipse", como Otto certa vez nomeou o grupo, tiveram contato com outros escritores do meio literário e jornalístico na então capital federal. Rubem Braga foi um dos que encontraram maior afinidade com eles e chegou a ser considerado o quinto cavaleiro do grupo. Ver WERNECK, Humberto. O Desatino da Rapaziada, São Paulo, Companhia das Letras, 1992, p. 101 e BETELLA, Gabriela Kvacek. "Os quatro cavaleiros de um íntimo apocalipse e suas biografias vicárias: Fernando Sabino, Otto Lara Resende, Hélio Pellegrino e Paulo Mendes Campos na escrita de perfis", Estudos Avançados, vol. 21, nº 60, 2007, pp. 247-270.
} 
desse sistema, ampliando a história de grupo para constituir uma pequena comunidade, convocada a partilhar dos mesmos valores.

Em "O crime (de plágio) perfeito"160, Rubem Braga recorda do tempo em que morava na capital paulista - "por volta de 1933, ou 4" - e escrevia para o jornal O Diário de São Paulo. Além da crônica diária, Braga era responsável pela reportagem e fazia outros serviços de redação, e tinha ainda bicos por fora. Um deles era a colaboração para o então recém-fundado O Interventor, cujo dono, Laio Martins, era "muito amigo". A remuneração era pouca, mas Braga "não queria faltar ao amigo". A relação de amizade, o vínculo cordial, como se vê, se sobrepõe à relação profissional.

Depois de escrever com certa regularidade, Braga começa a falhar e argumenta com o dono do jornal não querer "tomar partido na política paulista". Martins Ihe recomenda, então, utilizar um pseudônimo. Ainda assim, atarefado, Braga resolve copiar uma crônica de Carlos Drummond de Andrade, também assinada sob pseudônimo, publicada no jornal Minas Gerais. Laio Martins acha a crônica "esplêndida" e, a partir de então, Braga passa a usar o expediente de encarregar "um menino da portaria" de copiar a crônica.

O cronista afirma que não sentia muito remorso, e explica: Drummond não sabia de nada e não se tratava propriamente de plágio, pois o texto copiado não era matéria assinada pelo poeta, nem Braga se apropriava do trabalho com seu nome (ele usava o mesmo pseudônimo de Drummond). Ele pagava uma quantia ao menino, continua, e todos ficavam felizes: o dono do jornal, o menino, os leitores, ele próprio. E acrescenta que, em Minas, Drummond não era infeliz, pois não sabia do esquema.

Aqui, ainda uma vez, a explicitação das condições de trabalho: atarefado com tantas funções no jornal, e ainda fazendo bicos por fora, o cronista aceita mais um trabalho para não faltar com o amigo-patrão. Incapaz de cumprir tantas atividades, desculpa-se dizendo não querer tomar partido na política de terra que não é a dele. O ardil da cópia de cronista amigo se repete para escapar à pressão da publicação diária.

Diferentemente das crônicas mais líricas, essas estão mais fundadas no dado referencial, e acabam afinal nos mostrando de maneira mais acurada os sortilégios do ofício. É possível ver também a colaboração mútua dos cronistas, que, pressionados pela publicação diária, têm de se ajudar uns aos outros para cumprir os prazos exigidos.

\footnotetext{
${ }^{160}$ BRAGA, Rubem. A traição das elegantes, op. cit., p. 67-69.
} 


\subsection{Figuras humildes}

No item anterior, abordamos de maneira lateral a recorrência de personagens pobres em dois autores da crônica moderna. O intuito era mais caracterizar a partir de que ponto de vista eles nos falavam do que propriamente analisar a representação dos de baixo. Nas crônicas em que são retratadas as camadas pobres, parece ser mais fácil estabelecer o lugar social do narrador, pois o antagonismo se apresenta por inteiro. Em outros termos, os traços característicos desse narrador se mostram de maneira mais ostensiva na relação com o seu outro de classe. É o que pretendemos analisar a seguir.

Em "Quem sabe deus está ouvindo"161, Braga conta a história do cajueiro que nasce e começa a crescer em seu apartamento, por ter inadvertidamente jogado na terra o caroço da fruta.

\section{Quem sabe deus está ouvindo}

Outro dia eu estava distraído, chupando um caju na varanda, e fiquei com a castanha na mão, sem saber onde botar. Perto de mim havia um vaso de antúrio; pus a castanha ali, calcando-a um pouco para entrar na terra, sem sequer me dar conta do que fazia.

Na semana seguinte a empregada me chamou a atenção: a castanha estava brotando. Alguma coisa verde saía da terra, em forma de concha. Dois ou três dias depois acordei cedo, e vi que durante a noite aquela coisa verde lançara para o ar um caule com pequenas folhas. É impressionante a rapidez com que essa plantinha cresce e vai abrindo folhas novas. Notei que a empregada regava com especial carinho a planta, e caçoei dela:

- Você vai criar um cajueiro aí?

Embaraçada, ela confessou: tinha de arrancar a mudinha, naturalmente; mas estava com pena.

— Mas é melhor arrancar logo, não é?

Fiquei em silêncio. Seria exagero dizer: silêncio criminoso - mas confesso que havia nele um certo remorso. Um silêncio covarde. Não tenho terra onde plantar um cajueiro, e seria uma tolice permitir que ele crescesse ali mais alguns centímetros, sem nenhum futuro. Eu fora o culpado, com meu gesto leviano de enterrar a castanha, mas isso a empregada não sabe; ela pensa que tudo foi obra do acaso. Arrancar a plantinha com a minha mão - disso eu não seria capaz; nem mesmo dar ordem para que ela o fizesse. Se ela o fizer, darei de ombros e não pensarei mais no caso; mas que o faça com sua mão, por sua iniciativa. Para a castanha e sua linda plantinha seremos dois deuses contrários, mas igualmente ignaros: eu, o deus da Vida; ela, o da Morte.

Hoje pela manhã ela começou a me dizer alguma coisa - "seu Rubem, o cajueirinho..." - mas o telefone tocou, fui atender, e a frase não se completou. Agora mesmo ela voltou da feira; trouxe um pequeno vaso com terra e transplantou para ele a mudinha.

Veio me mostrar:

\footnotetext{
${ }^{161}$ BRAGA, Rubem. Ai de ti, Copacabana!, op. cit., p. 209-211.
} 
- Eu comprei um vaso...

- Ahn...

Depois de um silêncio, eu disse:

- Cajueiro sente muito a mudança, morre à toa...

Ela olhou a plantinha e disse com convicção:

— Esse aqui não vai morrer, não senhor.

Eu devia Ihe perguntar o que ela vai fazer com aquilo, daqui a uma, duas semanas. Ela espera, talvez, que eu o leve para o quintal de algum amigo; ela mesma não tem onde plantá-lo. Senti que ela tivera medo de que eu a censurasse pela compra do vaso, e ficara aliviada com minha indiferença. Antes de me sentar para escrever, eu disse, sorrindo, uma frase profética, dita apenas por dizer:

- Ainda vou chupar muito caju desse cajueiro!

Ela riu muito, depois ficou séria, levou o vaso para a varanda, e, ao passar por mim na sala, disse baixo, com certa gravidade:

- É capaz mesmo, seu Rubem; quem sabe Deus está ouvindo o que o senhor está dizendo...

Mas eu acho, sem falsa modéstia, que Deus deve andar muito ocupado com as bombas de hidrogênio e outros assuntos maiores.

Rio, janeiro, 1960.

Nos diálogos, fica patente a espera da empregada por uma ordem do patrão, mas em nenhum momento ele é explícito sobre o que fazer com o cajueiro. Ou seja, a empregada confessa que deve arrancar a muda, diz-se com pena e busca a confirmação, numa interrogativa-negativa (“Mas é melhor arrancar logo, não é?"), de que deve arrancála - em troca, recebe apenas o silêncio "criminoso" e "covarde" do cronista, que assim assume sua culpa de classe. O cronista, porém, se recusa tanto a arrancar a muda por suas próprias mãos, quanto a dar ordem para arrancá-la. "Se ela o fizer, darei de ombros e não pensarei mais no caso; mas que o faça com sua mão, por sua iniciativa." Quando a empregada aborda o patrão de novo, de maneira tímida e dócil ("Seu Rubem, o cajueirinho..."), é interrompida pelo toque do telefone. Depois que compra um vaso, o cronista sugere que talvez o cajueiro não vingue. Ele sente o medo que uma possível censura pela compra do vaso possa provocar nela e procura deixá-la à vontade, dizendo que espera chupar muito caju daquele pé. A empregada hesita entre o riso e a seriedade, talvez em dúvida se o que o patrão diz é verdade ou ironia. Ela diz, então, que espera que deus esteja ouvindo. Em pensamento, o cronista ironiza a fala da empregada, por achar que deus está ocupado com questões maiores.

Nessa conversa reticente, lacunar, mal se disfarça o constrangimento do cronista em assumir a opressão de classe. Desimcumbindo-se do ônus de arrancar o pé de caju, ele passa a tarefa à empregada, mas sem uma ordem direta. O movimento é sugestivo, elíptico, tudo fica como que pairando no ar. O vaivém da conversa lembra uma espécie de 
"negaceio"162, em que afirmações mais contundentes são seguidas de subentendidos, nada do que se diz é o que realmente se quer dizer, tudo sendo composto por acenos, recuos, meneios.

Um dos temas centrais dessa crônica, observa Henrique Balbi, é a morte iminente do cajueiro ${ }^{163}$, na qual o narrador alterna entre a ação, por meio da exposição dos diálogos com a empregada, e a reflexão, como uma espécie de confissão que o colocaria mais próximo do leitor. De acordo com o autor, a crônica busca "capturar a atenção do leitor e envolvê-lo nesse processo de súbita compreensão da precariedade de sua própria vida." A oração final da crônica serviria, então, para estabelecer a irrelevância do cajueiro e, em consequência, de narrador e leitor, afinal identificados com o pé da fruta, em face das grandes questões com as quais a providência divina teria de se ocupar.

O autor percebe bem os movimentos de aproximação e distanciamento do narrador, os quais por sua vez colocam o leitor ora frente à ação, ora acompanhando suas divagações. Mas cremos que isso ainda não diz tudo. Pois, como se sabe, de saída já existe um desnível entre cronista e empregada - além de ser patrão da doméstica, o narrador é aquele que possui a palavra. Quer dizer, os dramas de sua (má-)consciência são privilégio de quem tem a prerrogativa da palavra, que pode refletir sobre a situação e nuançar 0 conflito. Do outro lado, é a empregada, surpreendentemente, quem convoca à ação e toma as decisões: chama a atenção para o crescimento do cajueiro, compra o vaso, nega "com convicção" que o cajueiro vá morrer.

Como se sabe, a presença de tipos humildes é recorrente nas crônicas de Braga. Davi Arrigucci Jr. observa essa presença num espectro mais abrangente: em suas histórias, há uma "constante aproximação às formas da vida e do trabalho simples"164, as quais, segundo o crítico, ganhariam concretude em objetos esquecidos, coisas antigas, entes da natureza, seres e coisas humildes em geral. Arrigucci chama a atenção para a capacidade do cronista em perceber o "desvanecimento de tudo", especialmente "sensível à fugacidade irremissível do mais frágil, que, quase sempre, é também o mais pobre”.

Observando essa recorrência já indicada por Arrigucci Jr., Rafael Ireno procurou analisar de forma mais detida a representação de uma empregada doméstica numa crônica

\footnotetext{
162 WISNIK, José Miguel. Machado Maxixe: O Caso Pestana, São Paulo: Publifolha, 2008, p. 34-37. O crítico comenta nesse estudo o conto "Um homem célebre", de Machado de Assis, no qual o compositor Pestana, desejoso de criar grandes obras eruditas, só é bem-sucedido ao compor maxixes. Resumindo um pouco grosseiramente, Wisnik atenta para os nexos entre ritmos brasileiros - que, ao contrário da métrica europeia, regular no compasso, incluem desvios e defasagens na pulsação musical - e o próprio movimento da sociedade brasileira, oscilante entre a ordem e a desordem. 163 BALBI, Henrique. "O meditador e o observador: o narrador nas crônicas de Rubem Braga e Fernando Sabino", Opiniães, n.ㅇ 9, 2016, p. 166-7.

${ }_{164}$ ARRIGUCCI JR., Davi, "Braga de novo por aqui", op. cit., p. 41.
} 
específica do autor ${ }^{165}$. Em "Dona Teresa"166, o cronista fala sobre sua relação com essa empregada, que ele contrata quando passa um ano em Paris. Quase sem enredo, a crônica se concentra nas relações do cronista com Mme Thérèse. Num vaivém de lembranças - a mulher cai doente por causa da corrente de ar, adverte o cronista sobre o vento constante e lembra que sua antiga patroa adoeceu e morreu por causa disso - a empregada parece querer lembrar o cronista da iminência da morte, que por causa da idade se avizinha para ela. Ireno observa que essa questão está ligada à fugacidade do mais frágil, de que fala Arrigucci Jr., e que esse tema está relacionado também ao estatuto menor da crônica, quando comparada aos outros gêneros literários. Braga, portanto, assumiria essa condição apequenada tanto eticamente, ao aproximar-se das coisas frágeis e das pessoas pobres, quanto esteticamente, ao figurá-las nesse gênero menor que é a crônica.

Essas observações, no entanto, deixam escapar algo que nos parece fundamental. Isto é, a iminência da morte é de fato o tema principal da crônica, mas se tomado apenas como assunto universal, que atinge a todos. Se, antes, a morte for vista de um ponto de vista de classe, ângulo que o leitor evidentemente acompanha, aí se pode vislumbrar que o cronista talvez esteja sugerindo um conflito implícito, que esconde mal o verdadeiro desejo da empregada: forçando um pouco a nota, o que Mme. Thérèse talvez deseje é a morte do patrão - ao sair do apartamento, ela fala para o cronista cuidar da tosse, mas diz, segundo as palavras do narrador, "sem esperança mais nenhuma". Formulando melhor, o que o cronista parece sentir é o desejo oculto da empregada de que ele pereça, apesar do tom irônico e bem-humorado. Do outro lado, as reiteradas queixas da empregada já idosa também parecem escamotear uma relação de exploração, já que a corrente de ar parece ser apenas mais uma causa, entre outras, da condição precária de sua saúde, debilitada muito provavelmente por conta do trabalho pesado que desempenha.

Em "Albertine disparue"167, Fernando Sabino mostra uma relação mais direta e crua com sua empregada - e também mais preconceituosa, digamos. O título da crônica, emprestado a um dos volumes de Em busca do tempo perdido, de Marcel Proust, sugere uma elevação que, já na primeira sentença, é rebaixada: o nome da empregada é Albertina, "mas era a própria Nega Fulô". A adversativa opõe o nome prestigioso às qualificações do cronista sobre a empregada: "pretinha, retorcida, encabulada". Há outra referência à

\footnotetext{
165 IRENO, Rafael da Cruz. "Uma leitura de Rubem Braga: a lição humilde de escrever crônicas”, Miguilim, vol. 3, n. 3, setdez/2014.

166 BRAGA, Rubem. "Dona Teresa”, A borboleta amarela, op. cit., p. 47-48.

167 SABINO, Fernando. "Albertine Disparue", O homem nu, Ed. José Olympio, Rio de Janeiro, 1973, p. 176-179. Devo a Walter Garcia a indicação sobre a representação de empregadas domésticas nas crônicas de Sabino.
} 
tradição literária: "Essa negra fulô", poema do modernista Jorge de Lima, conta das relações entre uma escrava doméstica e seus proprietários.

$\mathrm{Na}$ crônica de Sabino, pode-se observar como essas relações, ainda que com feição transformada, estão ainda bem presentes. O patrão a instrui sobre as tarefas domésticas, se impacienta com a incompreensão sobre as atividades passadas, irrita-se com a ordem dos afazeres e com a falta de autonomia para executá-los, implica com recados telefônicos não anotados e com a opção religiosa da doméstica.

A irritação chega ao auge quando, um dia, a empregada chega "bêbada feito um gambá". O cronista ordena que ela durma e vá embora no dia seguinte. Em seguida, tranca a porta da cozinha, "deixando-a nos seus domínios". Ela ainda pede uma última vez para ficar, mas o cronista alega que não precisará mais de empregadas. "Nenhuma empregada?”, pergunta Albertina. "Nenhuma”, responde o cronista. Albertina se dá, então, por satisfeita, já que ninguém lhe ocupará o posto.

O trecho final, acima parafraseado, é esclarecedor: para provocar o riso, o cronista representa a empregada como ingênua, como alguém que acredita na palavra do patrão, já que a intenção parece ser antes livrar-se do incômodo do que propriamente explicar o motivo da dispensa. Mas, ao mesmo tempo, ele a figura como esperta, como alguém que já está imerso na esfera competitiva do mercado de trabalho e luta para não perder o posto. Assim, já que a vaga não está mais disponível, Albertina se tranquiliza ${ }^{168}$.

A nota de humor adviria também da dependência extrema da empregada para receber ordens, de sua falta de entendimento das tarefas a cumprir, da opção religiosa que não é bem vista pelo patrão. Porém, quando vista de uma perspectiva de classe, a história muda de figura: o riso fica apenas entre certa camada média que forma o público-leitor do jornal, numa confirmação recíproca de pertencimento que exclui os de baixo - ou que os exclui justamente para se afirmar.

É na mesma linha que outro cronista, Paulo Mendes Campos, aborda sua relação com empregadas domésticas. A crônica "Minhas empregadas"169, do livro O cego de Ipanema, tem o título inspirado, segundo o autor, num livro francês moderno, de nome "Minhas embaixadas". Aqui, ainda uma vez, a inspiração prestigiosa serve de mote para assunto rebaixado.

\footnotetext{
${ }^{168}$ Em entrevista, Roberto Schwarz lembra do incômodo da classe média com a escassez de empregadas domésticas no início dos anos 1960. Para o crítico, as empregadas preferiam "o jugo impessoal da fábrica ao capricho humilhante das patroas", ainda que com menores salários. "Agregados antigos e modernos", Martinha versus Lucrécia, op. cit., p. 177.

${ }^{169}$ CAMPOS, Paulo Mendes. O cego de Ipanema, Editora do Autor, Rio de Janeiro, 1960, p. 185-8.
} 
Mendes Campos lamenta o fato de que, ao contrário de sua amiga Clarice Lispector, ele costuma ter empregadas do tipo "débil mental". Clarice teria a sorte de contratar domésticas que possuiriam "certas finuras de reações psicológicas", que acabam por dizer coisas que "imitam-lhe a arte"170. Ele, por sua vez, teria empregadas que "não brilham pela sutileza".

Iniciando os relatos sobre as empregadas, o cronista abre no entanto com o que chama de exceção. Jandira, "escurinha e endiabrada", é descoberta copiando poemas de um livro de Carlos Drummond de Andrade pertencente ao cronista, que jamais imaginava "que ela alimentasse inquietações". Quando é despedida, o cronista afirma que ela havia furtado dele o livro A rosa do povo, de Carlos Drummond de Andrade.

Seguem relatos sobre a "preta Benedita", evangélica e vegetariana, que prega ao cronista tanto a religião quanto a dieta alimentícia. Contrariado, o cronista combate "essa intromissão" exigindo bifes sangrentos.

Depois de Benedita, entra em seu lugar sua filha Djídji, "a mais feia, a mais vesga, a mais triste, a mais torta, a mais lenta, a mais desamparada, a mais sonsa, a mais sonâmbula de todas as minhas empregadas". A enumeração é desnorteante e difícil de engolir. Mas o relato segue no ritmo desconcertante: o grau de submissão é tanto que Djídji "fazia o café, mas não servia". Com a cafeteira na mão, pronta para servir, perguntava com "perplexidade cósmica": "Despeja?". O grau de dependência e submissão é tamanho que a empregada não consegue dispor da autonomia necessária para efetivar uma ação; compreendesse o patrão os receios que uma repreensão pudesse causar, por conta de seus caprichos, talvez ele não fizesse troça nem exporia uma situação vexatória como essa.

O cronista ainda discorre sobre a eficácia relativa da educação dos filhos de famílias burguesas no Rio, já que é só "transpor a porta da cozinha" e é "a própria África, com seus orixás, quebrantos, exus, embaixadas, catimbós, histórias muito mais atraentes à imaginação infantil do que as nossas migalhas realistas". Talvez mais do que o preconceito religioso, o que se pode depreender do trecho é mesmo o preconceito racial. Aqui também, como na crônica de Sabino (o qual tranca a empregada alcoolizada "nos seus domínios"), as acomodações das domésticas são contíguas às áreas de serviço,

\footnotetext{
170 Vilma Arêas observa que leitores de Clarice Lispector, entre eles Paulo Mendes Campos, notaram a persistência de empregadas domésticas na obra da escritora. "Caco de vidro joia rara", Scripta, Belo Horizonte, vol. 1, nํㅜ 1, 2ํㅗ. sem. 1997, p. 174. Tânia Cristina Souza Borges, por sua vez, estudou a representação de empregadas domésticas tanto em romances - principalmente em $A$ paixão segundo G.H. e $A$ hora da estrela - quanto em crônicas de Lispector, reunidas em $A$ descoberta do mundo. "A culpa é minha" ou "A hora da estrela"?: uma análise do romance $A$ hora da estrela de Clarice Lispector. Dissertação de mestrado, FFLCH-USP, 2013, p. 14-36.
} 
ocupando um espaço próximo e dependente. Essa organização preservaria certa lógica própria à habitação da antiga casa-grande ${ }^{171}$.

De outra empregada, o cronista conta das origens semelhantes, de Minas Gerais, e da reticência dela em preparar certos pratos, por achar que o escritor é estrangeiro. 0 autor reproduz a fala da empregada, procurando destacar os erros e qualificando-a de "anafalbetismo culinário". Até o dia em que, segundo o cronista, encontrou-a estendida no chão, "a queixar-se do coração e da idade", depois de beber todo o seu vinho, toda a sua cerveja, todo o seu gim e o seu restinho de uísque.

Para finalizar, vale lembrar que o cronista conta sobre outra empregada que chegara atrasada um dia, porque "o temporal da véspera carregara seu barraco e seus pertences". O cronista diz sentir pena da empregada, que por sua vez o consola, dizendo que é preciso chover para o bem da lavoura. Também aqui, o cronista ironiza a fala da empregada, expondo o que seriam impropriedades para uma linguagem culta.

Ou seja, é possível ver aí que o cronista não se solidariza verdadeiramente com situações de desamparo, como doença ou perda da casa. Quando diz lamentar esses episódios, a expressão é pontuada de ironia e descrença, além de tentar extrair humor expondo a maneira de falar das empregadas. Aliás, tanto em Sabino quanto em Mendes Campos a fala popular contrasta com o universo prestigioso da cultura francesa, referência com a qual iniciam suas crônicas, opondo elite cosmopolita ilustrada e ralé provinciana analfabeta.

Assim, lidas em conjunto, as crônicas de Sabino e Mendes Campos expõem a desfaçatez da elite na relação com os estratos mais baixos. No caso de Braga, há ligeira mudança de tom, pois há uma leve preocupação com a empregada, na percepção da relação de submissão com a doméstica, assim como na hesitação em relação a essa obediência. Tudo isso revela o mal-estar do cronista diante da opressão de classe. Nesse sentido, Braga está mais próximo dos primeiros modernistas, principalmente de Mário de Andrade, que, em sua pesquisa do país real, procurou se aproximar do homem do povo. Ana Paula Pacheco nos mostra que este outro de classe, retratado pelo primeiro modernismo, invariavelmente trazia "a marca da afetividade, da solicitude (humilde ou

\footnotetext{
${ }^{171} \mathrm{Em}$ comentário sobre a influência da missão francesa que viera à Universidade de São Paulo formar os primeiros alunos, Gilda de Mello e Souza aborda um estudo de Roger Bastide sobre a cidade de São Paulo, cuja lógica vertical estaria em contradição com a sensibilidade horizontal descrita por Gilberto Freyre em Casa Grande e Senzala e Sobrados e Mocambos. Diferentemente do modelo europeu, no qual os apartamentos são separados segundo os grupos (burguesia rica nos primeiros andares, camadas médias nos andares intermediários e pobres nos sótãos), em São Paulo os edifícios misturam ricos e pobres no mesmo andar e destinam as acomodações dos domésticos ao lado da cozinha, reproduzindo a proximidade e dependência destes em relação aos patrões. "A Estética rica e a Estética pobre dos professores franceses", Exercícios de Leitura, 2. a ed., São Paulo: Duas Cidades; Ed. 34, 2009, p. 24-25.
} 
astuta), da paciência inimiga da raiva"172, traços que subsistem na crônica de Braga. Nos anos 40, diz a autora, Mário de Andrade inflete sua obra, passando da representação do homem do povo em direção ao questionamento de classe do intelectual ${ }^{173}$. Parece ser um caminho que Braga traçaria anos mais tarde, também passando da aproximação aos tipos humildes para o questionamento de seu locus social, como veremos no próximo tópico.

Assim, quando se pensa na fórmula da crônica moderna, com a poesia, o humor e o fato miúdo, não se pode deixar de vê-la permeada por uma perspectiva de classe. Podese argumentar, nesses casos, que realmente há poesia, por exemplo, na fala popular ou em achados de linguagem, mas o efeito lírico é extraído dos pobres em favor da elite; o riso também é obtido das classes baixas para satisfação das camadas médias e altas, que formam o público-leitor; o fato é miúdo apenas a partir de um ponto de vista (na outra ponta, mais fraca, não se sabe se o episódio narrado é realmente coisa pequena).

172 PACHECO, Ana Paula. "Cidade-cárcere: violência e representação das classes baixas na literatura brasileira contemporânea", Terceira Margem, Rio de Janeiro, n.16, jan-jun/2007, p. 31.

173 lbid., p. 35 


\section{Sinais da mudança de uma fórmula}

4.1. Problemas e impasses

"A traição das elegantes"174 conta o incômodo do cronista ao ver as fotos das mulheres mais elegantes daquele ano. Ele não consegue, a princípio, definir a razão desse incômodo e vai especulando sobre os motivos.

\section{A traição das elegantes}

As fotos estão sensacionais, mas algumas das elegantes não souberam posar - confessou Ibrahim Sued a respeito da reportagem em cores sobre as "Mais Elegantes de 1967" publicada em Manchete.

A verdade é mais grave, e todos a sentem: as "Mais Elegantes" estão às vezes francamente ridículas, às vezes com um ar boboca e jeca, às vezes simplesmente banais. A culpa não será de Ibrahim, nem do fotógrafo, nem da revista, nem das senhoras; o que aconteceu é misterioso, desagradável, mas completamente indisfarçável: alguém ou, digamos, Algo, Algo com maiúscula, fez uma brincadeira de mau gosto, ou talvez, o que é pior, uma coisa séria e não uma brincadeira; como se fossem as três palavras de advertência que certa mão traçou na parede do salão de festim de Baltazar; apenas não escreveu nas paredes, mas nas próprias figuras humanas, em seus olhos e semblantes, em suas mãos e seus corpos: "Deus contou o dia de teus reinos e lhes marcou o fim; pesado foste na balança, e te faltava peso; dividido será o teu reino."

Oh, não, eu não quero ser o profeta Daniel da Rua Riachuelo; mas aconteceu alguma coisa, e essas damas que eram para ser como símbolos supremos de elegância e distinção, mitos e sonhos da plebe, Algo as carimbou na testa com o "Mane, Tekel, Farés" da vulgaridade pomposa e fora de tempo. Oh, digamos que escapou apenas uma e que há uma outra que não está assim tão mal. Mas as 12 restantes (pois desta vez são 14), que aura envenenada Ihes tirou o encanto, e as deixou ali tão enfeitadas e tão banais, tão pateticamente sem graça, expostas naquelas páginas coloridas como risíveis manequins em uma vitrina de subúrbio?

Que aconteceu? Ninguém pode duvidar da elegância dessas damas, mesmo porque muitas não fazem outra coisa a não ser isto: ser elegantes. Elas são parte do patrimônio emocional e estético da Nação, são respeitadas, admiradas, invejadas, adoradas desde os tempos de Sombra; vivem em nichos de altares invisíveis, movem-se em passarelas de supremo prestígio mundano - e subitamente, oh! ai! ui! um misterioso Satanás as precipita no inferno imóvel da paspalhice e do tédio, e as prende ali, com seus sorrisos parados, seus olhos fixos a fitar o nada, estupidamente o nada - quase todas, meu Deus, tão "shangai", tão "shangai" que nos inspiram uma certa vergonha - o Itamarati devia proibir a exportação desse número da revista para que não se riam demasiado de nós lá fora!

Não sou místico; custa-me acreditar que algum Espírito Vingador tenha feito esse milagre ao contrário. A culpa será talvez da "Revolução", que tornou os ricos tão seguros de si mesmos, tão insensatos e vitoriosos e ostentadores e fátuos que suas mulheres perderam o desconfiômetro, e elas envolvem os corpos em qualquer pano berrante que melífluos costureiros desenham e dizem - "a moda é isto" - e se postam ali, diante da população cada vez mais pobre, neste país em que minguam o pão e o remédio, e se suprimem as liberdades - coloridas e funéreas, ajaezadas, e ocas, vazias e duras, sem espírito e sem graça nenhuma.

Há poucos meses, ao aceno de uma revista americana, disputaram-se algumas delas a honra de serem escolhidas, como mocinhas de subúrbio querendo ser misses, e no fim apareceram numas fotos de publicidade comercial, prosaicamente usadas como joguetes de gringos espertos. Desta vez é pior: não

\footnotetext{
${ }^{174}$ BRAGA, Rubem. A traição das elegantes, op. cit., p. 205-8.
} 
anunciam nada a não ser a inanidade de si mesmas, tragicamente despojadas de seus feitiços.

Direis que essa derrota das "Mais Elegantes" não importa... Importa! As moças pobres e remediadas, a normalista, a filha do coronel do Exército que mora no Grajaú, a funcionária da coletoria estadual de Miracema, a noiva do eletricista todas aprenderam a se mirar nessas deusas, a suspirar invejando-as, mas admirando-as; era o charme dessas senhoras, suas festas, suas viagens, suas legendas douradas de luxo que romantizavam a riqueza e o desnível social; eram aves de luxo que enobreciam com sua graça a injustiça fundamental da sociedade burguesa.

Elas tinham o dever de continuar maravilhosas, imarcescíveis, magníficas. É possível que pessoalmente assim continuem; mas houve aquele momento em que um vento escarninho as desfigurou em plebeias enfeitadas, em caricaturas de si mesmas, espaventosas e frias. Quero frisar que dessas senhoras são poucas as que conheço pessoalmente, e lhes dedico a maior admiração e o mais cuidadoso respeito. Não há, neste caso, nenhuma implicação pessoal. Estou apenas ecoando um sentimento coletivo de pena e desgosto, de embaraço e desilusão: nossas deusas apareceram de súbito a uma luz galhofeira, ingrata e cruel; sentimo-nos traídos, desapontados, constrangidos, desamparados e sem fé.

É duro confessar isto, mas é preciso forrar o coração de dureza, porque não sabemos se tudo isso é o fim de uma era ou o começo de uma nova era mais desolada e difícil de suportar.

Ao longo de praticamente toda a crônica, o narrador divaga sobre os porquês de ter pressentido algo de errado nas fotos das mulheres "mais elegantes" do ano, publicadas numa edição da revista em que escreve. No entanto, de saída ele descarta a culpa dos envolvidos na reportagem: não são responsáveis a revista, o colunista, o fotógrafo nem as próprias mulheres retratadas.

As ressalvas a todo momento à isenção de culpa das mulheres têm o propósito de não indispor o cronista com elas. Assim, num primeiro momento, ele diz que uma das mulheres escapa daquela "vulgaridade pomposa" e outra não está "tão mal assim". Logo a seguir, com uma expressão de razoabilidade, convoca o leitor a participar da comunidade dos homens de bom senso: "Ninguém pode duvidar da elegância dessas mulheres", pois estas seriam "patrimônio estético e emocional da Nação". Por último, o cronista reforça que não há "implicação pessoal" com nenhuma das mulheres: "Quero frisar que dessas senhoras são poucas as que conheço pessoalmente, e lhes dedico a maior admiração e o mais cuidadoso respeito". Trata-se de uma posição complicada, a meio caminho entre a crítica e a conciliação, com o cronista equilibrando-se entre dois polos.

O outro polo é o das "moças pobres e remediadas", que se espelham nas mulheres elegantes, e a quem o cronista presta a sua solidariedade. Evoca-se, também aqui, as figuras humildes tão frequentes na obra de Braga: "a normalista, a filha do coronel do Exército que mora no Grajaú, a funcionária da coletoria estadual de Miracema, a noiva do eletricista". Apesar da preocupação com as moças humildes, o cronista critica as elegantes 
justamente evocando lugares marcadamente pobres: em determinado momento, ele diz que as elegantes se parecem com manequins em "uma vitrina de subúrbio". A crítica com viés de classe também aparece quando o cronista afirma que as elegantes se transformaram em "plebeias enfeitadas". Em outro trecho, ao comentar uma seleção de modelos para uma revista americana, da qual algumas das elegantes participaram, ele diz que elas parecem "mocinhas de subúrbio querendo ser misses". Aqui, há uma crítica também à subserviência das mulheres à publicação norte-americana e, por extensão, da elite rica do país ao influxo estrangeiro. Isso porque elas valorizariam antes o que vem de fora, permitindo-se serem vendidas "como joguetes de gringos espertos", em troca da visibilidade internacional. A perspectiva estrangeira também é evocada em outro trecho, quando o cronista sugere em tom de galhofa a proibição da venda, em outros países, da edição de Manchete com as mulheres elegantes, mostrando-se preocupado com a imagem do país no exterior.

Assim, a preocupação com a posição do país no jogo internacional insere o cronista numa elite cosmopolita ilustrada. Além do mais, ele demonstra erudição ao citar uma passagem bíblica e também usa de uma diç̧ão empolada, empregando a segunda pessoa do plural ("Direis que essa derrota das 'Mais Elegantes' não importa...") e um vocabulário sofisticado ("melífluos", "fátuos", “imarcescíveis", "funéreas”, "ajaezadas”). É dessa perspectiva prestigiosa que ele irá criticar as elegantes, colocando-se acima delas, embora o meio social partilhado e as sucessivas ressalvas demonstrem uma proximidade efetiva, embora implícita. Por sua vez, a aproximação às moças pobres, explícita, será de cunho apenas moral. Por esse prisma, não parecem ser as elegantes que traíram as pobres, e sim o cronista que traiu as elegantes - uma verdadeira traição de classe.

Também é possível ver, ao longo da crônica, a mudança do registro místico-religioso para o histórico-social. No primeiro registro, utilizado na parte inicial da crônica, as explicações têm motivação divina, com a evocação de uma passagem bíblica, predomina um léxico de sabor arcaico, que sugere uma atmosfera de mistério, além de as acusações ficarem no campo da moral.

A notação histórico-social vem à tona quando o cronista descobre insuficientes suas especulações e supõe, então, que a culpa seja da "Revolução", que escancarou a desigualdade social do país. Assim, os ricos se tornaram "tão seguros de si mesmos", que suas mulheres "se postam diante da população cada vez mais pobre, neste país em que mínguam o pão e o remédio, e se suprimem as liberdades"; a vida das elegantes romantizava "a riqueza e o desnível social" e mostrava "a injustiça fundamental da 
sociedade burguesa". A mudança é nítida e pode indicar uma tomada de consciência. Mas o cronista volta ao registro vago, atribuindo a "um vento escarninho" ou a uma "luz galhofeira" os motivos da mudança das elegantes. Assim, quando o léxico social parece avançar numa compreensão de problemas históricos do país, ele acaba regredindo ao tom moralizante e o argumento não avança, recaindo na oposição entre ricos e pobres, ostentação e carência.

Já em "Os pobres homens ricos"175, do mesmo volume, o narrador critica um amigo que se queixa de ter sido chamado de "boa-vida" por um jornal. Num jogo de palavras, o cronista afirma que a vida deveria ser boa para todos e que os homens ricos do país carecem de "apetite social", como o tiveram homens como Bernard Shaw, John Ruskin, William Morris e Kropotkin ${ }^{176}$. Em seguida, ele conta o caso de um conhecido que se tornou rico e o consulta para comprar um quadro. O cronista diz estar com pena do homem, pois vê que ele realmente gostara do quadro e sabe que ele gastaria aquela quantia numa noite, mas a "preocupação do negócio" estragava o prazer de possuir a obra.

Talvez se trate de falsas oposições: na primeira situação, o cronista se opõe ao amigo evocando ilustres intelectuais de esquerda; na segunda, o contraponto se funda na familiaridade com as artes plásticas. A falsa oposição se daria nos termos de elite intelectual/ilustrada, representada pelo cronista, versus elite econômica/mundana, representada pelo seu conhecido.

Nas duas crônicas, o narrador deixa ver o lugar social de onde produz: apesar da precariedade de seu trabalho, o meio em que circula e a classe a que pertence, e a que ele realmente presta sua solidariedade, são os da elite carioca. Esta, por sua vez, num caso como no outro, estaria descomprometida com as partes atrasadas do país, posição que gera desconforto no cronista. Ele, então, procura se desvencilhar de sua classe, mostrandose preocupado com as moças pobres, na primeira crônica, e evocando pensadores de esquerda, na segunda, o que indicaria um chamado à responsabilidade com o destino de populações historicamente relegadas. Embora não se relacionassem, talvez Rubem Braga pensasse como Mário de Andrade, que acreditava ser possível transpor as barreiras de

\footnotetext{
175 BRAGA, Rubem. A traição das elegantes, op. cit., p. 135-137.

176 O cronista cita passagem do prefácio de Major Barbara, peça do dramaturgo inglês George Bernard Shaw. A visão de mundo de Braga parece alinhar bem com a desses pensadores de esquerda, os quais postulavam uma crítica à civilização moderna que portava traços românticos, se tomarmos a concepção de Michael Löwy e Robert Sayre. Para esses autores, o romantismo não é somente um movimento artístico circunscrito no tempo, mas uma verdadeira visão de mundo, que "representa uma crítica da modernidade, isto é, da civilização capitalista, em nome de valores e ideais do passado (précapitalista, pré-moderno)". Revolta e melancolia: o romantismo na contracorrente da modernidade. Trad. Nair Fonseca, 1ª ed. São Paulo: Boitempo Editorial, 2015, p. 38. (Grifo dos autores.) Para saber mais sobre Ruskin, ver p. 163-185; sobre Morris, ver p. 112, 184-185.
} 
classe dedicando atenção às coisas do povo, direcionando suas ações para trazer dignidade às camadas baixas, explorando o potencial dos modos de falar da população mais pobre.

Assim, a colocação pronominal muito peculiar usada pelo escritor paulista procurava aproximar-se da linguagem falada do cotidiano popular, com seus desvios da norma erudita. Com isso, o líder do modernismo brasileiro pretendia denunciar o caráter "inculto do padrão culto do país", aspirando a uma "naturalidade superior"177. Sua linguagem "familiar mesmo quando empolada", certa "sinceridade nacionalista", seu "brasileirismo romântico" faziam crer que era possível à época a superação da clivagem entre ricos e pobres $^{178}$.

Mas a adoção da fala popular dizia respeito mais aos escritores que a pretendiam promover do que propriamente ao campo popular, o qual ela deveria atingir. Isto é, tratavase antes de uma atitude reformista, de ruptura com o padrão academicista, apenas no âmbito da linguagem. A integração nacional restava assim na dimensão restrita da cultura, ajustada ao molde familista, deixando à margem a ação política ${ }^{179}$.

Esse programa de busca do povo brasileiro, de pesquisa do país real, surge com o modernismo e prevalece até 1964. A partir daí, surge uma "nova visão desiludida e amarga da elite brasileira", ótica segundo a qual "a sinceridade e as simpatias populares da cultura oficial não eram tão confiáveis assim"180. Trata-se de uma mudança semelhante à que Machado de Assis experimentou no cerne de sua obra, quando, depois de perceber que nossa elite "não ia assumir a responsabilidade histórica" pelos estragos da escravidão, o escritor passa a desenvolver, a partir da publicação das Memórias Póstumas de Brás Cubas (1880), "os meandros de autojustificação e deformidade espiritual" do ponto de vista da "nossa gente civilizada"181. Do mesmo modo, na sua recepção crítica, o ceticismo de Machado só passa a ser compreendido depois do golpe de 1964, quando a perspectiva de integração estava rifada ${ }^{182}$.

Com efeito, os valores modernistas parecem encontrar seus limites e revelar seus impasses numa crônica como "A traição das elegantes", que mostra de que maneira, mesmo para um escritor preocupado com o destino dos mais pobres, as barreiras de classe só conseguem ser transpostas na dimensão cultural. Assim, ao observar a ostentação de

\footnotetext{
177 SCHWARZ, Roberto. "Outra Capitu”, Duas Meninas, São Paulo: Companhia das Letras, 1997, p. 138.

178 As expressões são de Roberto Schwarz em "Conversa sobre Duas Meninas", Sequências brasileiras, op. cit., p. 234.

179 Id., "Outra Capitu", op. cit., p. 140.

180 Id., "Conversa sobre Duas Meninas", op. cit., p. 234.

181 Id. "Outra Capitu", op. cit., p. 143.

182 Id., "Conversa sobre Duas Meninas", op. cit., p. 292.
} 
mulheres ricas numa revista, em um momento em que a integração dos estratos mais baixos já está fora do horizonte, o cronista consegue captar a gravidade da ruptura e constata que se trata do fim de uma era ou do começo de uma outra, mais "desolada e difícil de suportar".

A sensibilidade do cronista em prever as dificuldades de tempos futuros adviria, segundo John Gledson, de sua "extraordinária capacidade de tomar o pulso do tempo" lembremos que o golpe militar fora dado três anos antes da publicação da crônica e, no ano seguinte, seria baixado o Ato Institucional n. 5, com o endurecimento do regime. Gledson sugere então que, para uma nova geração de cronistas, esse estado de coisas não estaria propício às epifanias dos textos de Braga, "e a crônica mudaria de novo"183.

Em março de 1972, cinco anos depois da publicação de "A traição das elegantes", o Jornal da Tarde publica a matéria "Adeus, cronistas"184. Nela, o repórter José Márcio Mendonça entrevista alguns dos principais cronistas brasileiros - Clarice Lispector, Fernando Sabino, Rachel de Queiroz, Carlos Drummond de Andrade e Nelson Rodrigues - e constata, por meio dos depoimentos, que a crônica "está caindo de moda, quase sem que ninguém perceba. Morre em silêncio, depois de quase 12 anos de glória". No depoimento de Rubem Braga, o cronista afirma que praticou o gênero durante mais de 30 anos e se cansou. "Cansei mesmo de escrever, sou um homem aposentado como jornalista. Vivi, desde 16 anos, quase que exclusivamente de crônica, uma diária, para jornal, e outra semanal, para uma revista. Veio agora o esgotamento, o cansaço." Braga afirma que também há modas na literatura: houve o tempo do romance regionalista, que cansou, e o da crônica, que igualmente se esgotou.

Dois anos mais tarde, Antonio Dimas retoma essa reportagem para questionar o lugar rebaixado a que a crônica sempre é destinada em relação a outros gêneros literários, mais prestigiosos aos olhos da crítica especializada. Dimas ressalta o aspecto financeiro e a efemeridade da crônica como razões para que tanto a crítica quanto os próprios escritores não deem importância ao gênero. Para ele, no entanto, para que se possa aferir o valor literário de uma crônica deve-se levar em conta a flutuação entre a literariedade e a referencialidade. Com isso, o crítico quer dizer que, quanto mais o escrito pesar para aquele primeiro aspecto, maior será o seu valor como objeto literário ${ }^{185}$.

\footnotetext{
183 GLEDSON, John, "Apresentação", op. cit., p. 30.

184 MENDONÇA, José Márcio. Adeus cronistas. Jornal da Tarde. São Paulo, 14 mar. 1972, p. 22-23.

185 DIMAS, Antonio. "Ambiguidade da crônica: literatura ou jornalismo?", em Revista Littera, n.12, Rio de Janeiro, set-dez 1974, p.46-51.
} 
Porém, talvez essa literariedade que os cronistas dos anos 1950 buscaram incutir no gênero - com o lirismo, a nostalgia, o ar de conversa -, e que conferiu autonomia literária à crônica, não tivesse mais um lastro social. Isto é, abria-se naquela época a perspectiva para a almejada integração nacional, de que dá prova o ar cordial (aos olhos de hoje, paternalista) com que a elite culta dos escritores se aproximava da população pobre, ainda que essa aproximação estivesse restrita à linguagem familista. No entanto, já em algumas crônicas de Rubem Braga, que de certa forma cultivou valores modernistas, principalmente via Manuel Bandeira, vemos as dificuldades em transpor de modo efetivo as barreiras de classe, que obviamente não podiam ser derrubadas apenas no âmbito cultural. Na crônica sobre o cajueiro, por exemplo, o cronista explicita sua má-consciência e adota postura hesitante diante do seu outro de classe, ora fazendo valer seu privilégio, ora omitindo-se do conflito. Em cronistas da geração posterior, passa-se do mal-estar ao cinismo e à ironia, revelando a dessolidarização completa com os de baixo. Assim, mesmo antes do golpe militar, era possível ver a falta de compromisso de nossas elites, mesmo as ditas cultivadas, com a integração nacional.

Rubem Braga, especificamente, tinha postura ambivalente quando se referia de maneira mais direta ao golpe de 64 . O cronista alterna entre a indiferença, a ironia, a crítica, o tédio, o desgosto e o cansaço. Um ano depois da instalação do novo regime, por exemplo, ele relembra em crônica a sua experiência pessoal nos dias anteriores ao golpe. Na época, o cronista não estava trabalhando e visitava Petrópolis (RJ), quando ouviu fogos em comemoração ao acontecimento. "Na hora crucial creio que eu estava comendo uma empadinha no Dangelo e se telefonei para alguém foi para uma namorada que eu tinha naquele tempo", escreve, de maneira irônica. Para o cronista, a indiferença era geral, mesmo entre alguns militares: ele relata que, quando saiu de ônibus da cidade, duas passageiras celebraram uma tropa de soldados, os quais olharam "meio espantados" para os aplausos, por provavelmente não saberem se eram "contra ou a favor da Revolução"186.

Passados alguns meses, no entanto, o desinteresse de Braga começa a dar lugar a dúvidas e ele se questiona se deveria usar "'Revolução de 31 de março' ou 'golpe de $1^{\circ}$ de abril"” para se referir ao evento. Opta por um meio-termo: "Movimento de 64"187. A dúvida é suscitada para discutir o papel do Inquérito Policial Militar e seu uso contra adversários políticos. O cronista pensa que não se trata de algo grave e que esse "castigo" tem o objetivo de "chatear". É essa "longa e impiedosa chateação" que o ex-presidente Juscelino

\footnotetext{
${ }^{186}$ BRAGA, Rubem. "Lembrança da Revolução", Bilhete a um candidato \& outras crônicas sobre política brasileira, org. Bernardo Buarque de Hollanda, 1를 ed, Belo Horizonte, Autêntica Editora, 2016, p. 168.

187 Id., "Os IPMs e o Sr. Juscelino", op. cit., p. 186.
} 
Kubitschek enfrenta à época e Braga passa a questionar. Em outro artigo, o escritor discute a intimidação do regime sobre o Instituto Superior de Estudos Brasileiros, o Iseb, que também sofre um inquérito por "estudar os problemas brasileiros"188. Um mês antes, comenta que apoia o protesto de atores contra os excessos da censura e repudia a demissão de docentes e o espancamento de um professor inglês na Universidade de Brasília, constatando que a arte e a cultura não encontravam no país o clima ideal de liberdade ${ }^{189}$.

O cronista também se posicionou contra as torturas, que ocorriam desde o início do novo regime. Um ano após o golpe de 1964, Braga cobrava de Carlos Lacerda, então governador do Estado da Guanabara, providências a respeito da prisão e das torturas sofridas pelo jornalista José Fernandes Rêgo ${ }^{190}$. O secretário de Imprensa de Lacerda, Cel. Gustavo Borges, passa a repreender publicamente o cronista, em cartas enviadas ao Jornal do Brasil. Braga se demite da publicação e sofre um processo judicial por parte do coronel. Por causa desse processo, por cuidados com a censura ou simplesmente por tédio, como nos atesta seu biógrafo, prefere falar de banalidades em suas crônicas ${ }^{191}$. "Escreve sem vontade, copia trechos de antigos cronistas portugueses, comenta cartas e cita autores maiores e menores"192.

Ao mesmo tempo, o cronista demonstra certo desalento com a situação do país e nem sempre a política é assunto de suas colunas - nas revistas, prefere abordar temas mais amenos. Chega a ser cobrado por leitores, em novembro de 66, para falar mais diretamente da situação política do país.

Estranha uma gentil leitora que em tempos de agitação política escreva eu sobre coisas antigas e vagas ou subjetivas, e em vez de falar de cassações e eleições divague sobre mariposas, malacachetas, brisa do mar. E me chama de alienado - alienado no sentido moderno, do sujeito que está por fora dos problemas de seu tempo, e não no sentido antigo, de louco de hospício. ${ }^{193}$

Um ano depois, a cobrança vem de um amigo:

Recebo o recado de um amigo: "Você precisa escrever mais sobre política". E acrescenta que eu ando muito "alienado" ou "por fora", como se costuma dizer agora.

O amigo tem razão, mas o diabo é que não gosto de forçar minha natureza, e confesso que mal tenho lido as seções políticas dos jornais. O tédio me vence. ${ }^{194}$

\footnotetext{
188 Id., "Uma simples sugestão”, op. cit., p. 190-191.

189 Id., "O vereador, coitado", op. cit., p. 188-189.

190 Id., "E agora, Carlos?". Disponível em <http://docvirt.com/DocReader.net/AcervoRubemBraga/13272>. Acesso em 11 de março de 2018.

191 CARVALHO, Marco Antonio de., op. cit., p. 461.

192 lbid., p. 450.

193 BRAGA, Rubem. "Da importância dos 'cristãos-novos'”, op. cit., p. 204.

194 Id. "A política e o tédio", op. cit., p. 212.
} 
Já em 1975, recebe convite para trabalhar na TV Globo, escrevendo pequenos textos para serem lidos num telejornal e ganhando o dobro do que recebia na imprensa escrita ${ }^{195}$. No fim de 1978, é convidado a trabalhar para a recém-criada Revista Nacional. "Mas escreve sem vontade, sem ilusões, repete textos de décadas antes, sente 'gastura' de escrever. Refaz tantos trabalhos antigos que os amigos o chamam de 'Oficina de Reparos"'196. Não à toa, no primeiro ensaio de Davi Arrigucci Jr. sobre Braga, publicado em 1979 com o sugestivo título "Onde andará o velho Braga?", o crítico comenta a ausência do cronista nas páginas dos jornais naqueles anos. Na década de 1980, porém, Rubem Braga ainda viria a escrever para o jornal $O$ Estado de $S$. Paulo, onde publica sua última crônica, na véspera de sua morte.

Se o trabalho na imprensa parecia fatigar cada vez mais o cronista nessa época, o lançamento de livros dá novo fôlego à sua obra, ainda que as coletâneas publicadas tenham sido compostas, em sua maioria, de escritos antigos. Era o período da distensão, em que a abertura lenta, segura e gradual propiciava um ambiente um pouco mais arejado para a cultura brasileira, depois de anos de sufocamento. Em 1977, é lançada a coleção "Para gostar de ler"197, dirigida ao público jovem, que reunia crônicas dele, de Carlos Drummond de Andrade, Paulo Mendes Campos e Fernando Sabino, com prefácio de Antonio Candido. No ano seguinte, publica sua coletânea mais célebre, as 200 crônicas escolhidas, que hoje está em sua 38ª edição. Já nos anos 1980, Braga ainda teria editadas mais duas reuniões, em geral de crônicas antigas: Recado de primavera, de 1984, e As boas coisas da vida, de 1988, seu último livro publicado em vida.

Entre o fim dos anos 1950 e o início dos 1960, Rubem Braga viveu um período em que a arrancada modernizante parecia a ponto de levar o país a um patamar socialmente justo, além de integrá-lo ao concerto das nações civilizadas. Com a desilusão posterior, vinda com a instalação da ditadura militar, o cronista passou a ficar ainda mais cético do que já era naturalmente. A fórmula moderna da crônica, com a junção do "fato miúdo" e do "toque humorístico", acrescidos de poesia - equação que representaria o "amadurecimento" do gênero'198 -, ia, aos poucos, perdendo sentido naquela conjuntura.

\footnotetext{
195 Cf. CARVALHO, Marco Antonio de, op. cit., p. 521. Ainda que não tenha participado de modo mais combativo das lutas contra a ditadura, é interessante que Braga percorre um itinerário parecido com o de outros artistas ou intelectuais de esquerda no período: muitos deles passam a encontrar oportunidades de trabalho com a consolidação dos meios de comunicação de massa, em especial a televisão. A esse respeito, ver RIDENTI, Marcelo. "Intelectuais e romantismo revolucionário". São Paulo em Perspectiva, vol. 15 n. 2, São Paulo, abr-jun/2001, p. 18. O caso do teatro é emblemático, com autores como Dias Gomes e Oduvaldo Vianna Filho migrando para a dramaturgia televisiva da Rede Globo.

196 CARVALHO, Marco Antonio de, op. cit., p. 524.

197 O primeiro volume da coleção vendeu cerca de 200 mil exemplares em seis meses, segundo o biógrafo do cronista. lbid., p. 518.

198 A combinação é formulada por Antonio Candido em "A vida ao rés-do-chão", op. cit., p. 28.
} 
O que se seguiu ao golpe militar foi o retorno de uma velha burguesia, que havia ficado para trás durante o período de radicalização política do pré-64, em que sindicatos e associações lutavam pelas reformas de base, pelo salário mínimo e pelo voto dos analfabetos, como observou Roberto Schwarz ${ }^{199}$. Depois que os militares tomaram o poder, vinha à frente uma outra parcela da população, que recuperava fórmulas rituais baseadas na família, na pátria e na religião. Era "a revanche da província, dos pequenos proprietários, dos ratos de missa, das pudibundas, dos bacharéis em lei etc." ${ }^{200}$. Posta de lado em seguida pelo regime autoritário, que prescindiu dela para fazer a sua modernização conservadora, essa "liga dos vencidos" ainda teve chance de aparecer nas crônicas de Stanislaw Ponte Preta, no Festival de Besteira que Assola o País, (Febeapá), com seu "espetáculo de anacronismo social, de cotidiana fantasmagoria"201. Para John Gledson, essas crônicas traziam humor negro com um tom "desprendido, cínico, sabido, e um pouco impaciente"202.

Na mesma toada, o semanário Pasquim, com Millôr Fernandes, Sérgio Augusto, Jaguar, Henfil, Ivan Lessa, Dalton Trevisan, entre outros, apresentava um humor "perverso" e "pesado" na medida para os novos tempos, como pontuou Homero Araújo ${ }^{203}$. Sua intenção parecia ser a de "acusar os contrastes brasileiros sem apontar solução" ou "rir da solução consumista de classe média emoldurada pela violência e miséria da massa despossuída", numa "celebração macabra à luz das promessas conciliatórias que o desenvolvimentismo de Juscelino pressupunha"204. O humor negro, entre cético e cínico, os descalabros da ditadura, as personagens meio patéticas, meio obscuras, recendendo a velharia, comporiam os elementos da crônica de um novo e sinistro tempo.

\footnotetext{
199 Cf. SCHWARZ, Roberto. “Cultura e política 1964-1969”, op. cit., p. 83.

200 Ibid., p. 83

201 Ibid., p. 84

202 GLEDSON, John, "Apresentação”, op. cit., p. 33.

${ }^{203}$ ARAÚJO, Homero Vizeu. "Pasquim: humor negro, crítica e desmoralização ou Espírito de porco também é espírito crítico. In: Futuro pifado da literatura brasileira: promessas desenvolvimentistas e modernização autoritária. Editora da UFRGS, 2014, p. 133-134.

204 Ibid., p. 134.
} 


\section{Bibliografia}

Rubem Braga

BRAGA, Rubem. O conde e o passarinho e Morro do isolamento. 5ª ed., Rio de Janeiro: Record, 1982. . Um pé de milho. 4⿳亠丷厂 ed. Rio de Janeiro: Ed. Record, 1982. . O homem rouco. $2^{\mathrm{a}}$ ed., Rio de Janeiro: Ed. do Autor, 1963. . A borboleta amarela. Rio de Janeiro: José Olympio, 1955. A cidade e a roça. $2^{\mathrm{a}}$ ed. Rio de Janeiro: José Olympio, 1957. . Ai de ti, Copacabana! 2. ${ }^{\text {a }}$ ed. Rio de Janeiro: Editora do Autor, 1960. . A traição das elegantes. Rio de Janeiro: Ed. Sabiá, 1967. . 200 crônicas escolhidas. 26ª ed. Rio de Janeiro: Ed. Record, 2006. . Recado de primavera. 4ª ed. Rio de Janeiro: Record, 1986.

. Os segredos todos de Djanira \& outras crônicas sobre arte e artistas. André Seffrin (org.), $1^{\underline{a}}$ ed., Belo Horizonte: Autêntica Editora, 2016.

. Os moços cantam \& outras crônicas sobre música. Carlos Didier (org.), $1^{a} \underline{a}$ ed., Belo Horizonte: Autêntica Editora, 2016.

. Bilhete a um candidato \& outras crônicas sobre política brasileira. Bernardo Buarque de Hollanda (org.), $1^{\text {a }}$ ed., Belo Horizonte: Autêntica Editora, 2016.

. O poeta e outras crônicas de literatura e vida. Coordenação de André Seffrin. Seleção e prefácio de Gustavo Henrique Tuna. São Paulo: Global, 2017.

"Os defeitos de Macunaíma". Folha da Manhã. São Paulo, 4 de maio de 1937. Disponível em: <http://almanaque.folha.uol.com.br/semana5.htm>. . "E agora, Carlos?". Disponível em <http://docvirt.com/DocReader.net/AcervoRubemBraga/13272>.

Outros cronistas:

CAMPOS, Paulo Mendes. "Minhas empregadas", O cego de Ipanema, Editora do Autor, Rio de Janeiro, 1960. SABINO, Fernando. "O estranho ofício de escrever", A falta que ela me faz. 16 ${ }^{\underline{a}}$ ed. Rio de Janeiro: Record, 1980.

"Albertine Disparue", O homem nu, Ed. José Olympio, Rio de Janeiro, 1973.

Sobre Rubem Braga:

ARRIGUCI JR., Davi, "Braga de novo por aqui”, Enigma e comentário. Ensaios sobre literatura e experiência, São Paulo, Companhia das Letras, 1987.

"Onde andará o velho Braga?", in: Outros Achados e Perdidos. São Paulo: Companhia das

Letras, 1999.

BALBI, Henrique. "O meditador e o observador: o narrador nas crônicas de Rubem Braga e Fernando Sabino", Opiniães, n.ำ 9, 2016.

CANDIDO, Antonio; CASTELLO, José Aderaldo. "Rubem Braga", Presença da Literatura Brasileira, v. III, São Paulo: Difusão Europeia do Livro, 1964, p. 358-359.

CARVALHO, Marco Antonio de. Um cigano fazendeiro do ar. Rio de Janeiro: Globo, 2007. 
CHAVES. Flávio Loureiro. Crônicas e Mitos de Rubem Braga. In: O Brinquedo Absurdo. São Paulo: Polis, 1978.

DUBIELA, Ana Karla. A traição das elegantes pelos pobres homens ricos: uma leitura de crítica social em Rubem Braga. Vitória: Edufes, 2007.

Um coração postiço - a formação da crônica de Rubem Braga. Fortaleza: Banco do Nordeste do Brasil, 2010.

FRANCHETTI, Paulo E. A.; PÉCORA, Antônio Alcir B. (Org.). Rubem Braga. São Paulo: Abril, 1980. (Coleção Literatura Comentada).

GASPAR, Samantha dos Santos. "Rubem Braga e o semanário Comício: notas sobre uma experiência jornalística anti-varguista nos anos 1950", Anais do XXVI Simpósio Nacional de História - ANPUH, São Paulo, julho 2011.

GOMES. Danilo. Em torno de Rubem Braga. Brasília: Signo Editora, 1991.

HOLANDA, Sérgio Buarque de. "Braga no País das Maravilhas". Folha da Manhã, São Paulo, 28 de nov. 1951. Disponível em <http://almanaque.folha.uol.com.br/sergiobuarque braga.htm>.

IRENO, Rafael da Cruz. "Uma leitura de Rubem Braga: a lição humilde de escrever crônicas", Miguilim, vol. 3, n. 3, set-dez/2014.

MILLIET, Sérgio. Diário crítico, vol. 2, São Paulo: Martins Editora, 1981.

PAES, José Paulo. "Rubem Braga". Pequeno dicionário crítico de Literatura Brasileira, 6ª ed., São Paulo:

Cultrix, 2001 p. 86

PEREIRA, Lúcia Miguel. Correio da Manhã, Rio de Janeiro, 15 de jun. 1951. Caderno Cultura Brasileira, p.

11. Disponível em <http://memoria.bn.br/DocReader/089842 06/10039>.

RIBEIRO, Carlos Jesus. Caçador de Ventos e Melancolias: um Estudo da Lírica nas Crônicas de Rubem

Braga. Salvador: EDUFBA, 2001.

Rubem Braga: um escritor combativo. A outra face do cronista lírico. Rio de Janeiro: Editora

Booklink, 2013.

SIMON-BRÉSIL, Michel. "Avant-propos". In: BRAGA, Rubem. Chroniques de Copacabana, de Paris et d'ailleurs. Paris: Pierre Seghers, Éditeur, 1963, p. 8-9.

VERGARA, Anelize. Rubem Braga: Crônica e Censura no Estado Novo (1938-1939). Dissertação de mestrado, FCL-Unesp, 2014.

\section{Crônica:}

ARÊAS, Vilma. "Caco de vidro joia rara", Scripta, Belo Horizonte, vol. 1, n.1, 2.ำ sem. 1997.

ASSIS, Machado de. "Aquarelas - O folhetinista", in John Gledson (organização, introdução e notas), Machado de Assis - crônicas escolhidas, São Paulo: Penguin Classics Companhia das Letras, 2013.

ARRIGUCI JR., Davi, "Fragmentos sobre a crônica”, Enigma e comentário. Ensaios sobre literatura e experiência, São Paulo, Companhia das Letras, 1987, p. 51-66.

BORGES, Tânia Cristina Souza. "A culpa é minha" ou "A hora da estrela"?: uma análise do romance A hora da estrela de Clarice Lispector. Dissertação de mestrado, FFLCH-USP, 2013.

CANDIDO, Antonio, "A vida ao rés-do-chão", Recortes. $3^{\underline{a}}$ ed. revista pelo autor, Rio de Janeiro: Ouro sobre Azul, 2004, p. 26-34. 
“Dois cronistas". In: Textos de intervenção. São Paulo, Duas Cidades; Ed. 34, 2002, p. 205-210. "Drummond prosador". Recortes. $3^{\mathrm{a}}$ ed. revista pelo autor, Rio de Janeiro: Ouro sobre Azul, 2004, p. 13-23.

COELHO, Marcelo. Notícias Sobre a Crônica. In: CASTRO, Gustavo de, GALENO, Alex (org.); Jornalismo e literatura - A sedução da palavra. São Paulo: Escrituras, 2002.

COUTINHO, Afrânio, "Ensaio e crônica", A literatura no Brasil. v.6, São Paulo. Global, 2003, p. 117-143. DIMAS, Antonio, "Ambiguidade da crônica: literatura ou jornalismo?", em Revista Littera, n.12, Rio de Janeiro, set-dez 1974, p.46-51.

GLEDSON. John. "Apresentação". Conversa de burros, banhos de mar e outras crónicas exemplares. Lisboa, Cotovia, 2006.

NEVES, Margarida de Souza, "História da crônica. Crônica da história", em Beatriz Resende (org.), Cronistas do Rio, Rio de Janeiro, Ed. José Olympio, 1995, p. 15-31.

RONCARI, Luiz. "A estampa da rotativa na crônica literária", em Boletim Bibliográfico da Biblioteca Mario de Andrade, vol. 46, no 1 - 4, jan. dez. 1985, p. 9-16.

SÁ, Jorge de. A crônica, São Paulo, Ática, 1985.

VONK, Arthur Vergueiro. Ao rés do chão sem chão: Drummond e a crônica moderna brasileira. Dissertação de mestrado, FFLCH-USP, 2013.

\section{História da imprensa}

ABREU, Alzira Alves de. "Revisitando os anos 50 através da imprensa", BASTOS, Élide Rugai; BÔAS, Gláucia Villas; BOTELHO, André (orgs.). O moderno em questão: a década de 1950 no Brasil, Rio de Janeiro: Topbooks, 2008.

BETELLA, Gabriela Kvacek. "Os quatro cavaleiros de um íntimo apocalipse e suas biografias vicárias: Fernando Sabino, Otto Lara Resende, Hélio Pellegrino e Paulo Mendes Campos na escrita de perfis", Estudos Avançados, vol. 21, ํㅡ 60, 2007.

BLOCH, Arnaldo. Os Irmãos Karamabloch, São Paulo: Companhia das Letras, 2008.

MEYER, Marlyse, "Voláteis e versáteis. De variedades e folhetins se fez a crônica", em A crônica. O gênero, sua fixação e suas transformações no Brasil, Campinas/ Rio de Janeiro: Ed. Da Unicamp/ Fundação Casa de Rui Barbosa, 1992, p. 93-134.

RIBEIRO, Ana Paula Goulart. "Jornalismo, literatura e política: a modernização da imprensa carioca nos anos 1950". In: Estudos Históricos, Rio de Janeiro, no 31, 2003, p. 147-160.

WERNECK, Humberto. O Desatino da Rapaziada. São Paulo: Companhia das Letras, 1992.

\section{Geral}

ABREU, Maurício de Almeida. "O período 1950-1964", in Evolução urbana do Rio de Janeiro, 4ª ed., Rio de Janeiro: Instituto Pereira Passos, 2013.

ADORNO, Theodor W. "Palestra sobre lírica e sociedade". Notas de Literatura I. Tradução de Jorge de Almeida. São Paulo: 34, 2003. 
"Posição do narrador no romance contemporâneo", Notas de Literatura I, Tradução de Jorge de Almeida. São Paulo: 34, 2003.

ANDERSON, Benedict. "Introdução", Comunidades Imaginadas - Reflexões sobre a origem e a difusão dos nacionalismos. São Paulo: Companhia das Letras, 2008.

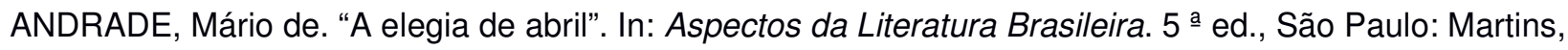
1974. Poesias completas. São Paulo: Martins, 1966.

ARANTES, Paulo Eduardo. "Nação e reflexão". Zero à esquerda. São Paulo: Ed. Conrad, 2004.

ARANTES, Paulo Eduardo et al., "Crítica de Intervenção", Rodapé, n. 3, nov/2004.

ARANTES, Pedro Fiori. "O crítico e os arquitetos". Um crítico na periferia do capitalismo. São Paulo: Companhia das Letras, 2008.

ARAÚJO, Homero Vizeu. "Pasquim: humor negro, crítica e desmoralização ou Espírito de porco também é espírito crítico. In: Futuro pifado da literatura brasileira: promessas desenvolvimentistas e modernização autoritária. Porto Alegre: Editora da UFRGS, 2014.

ARRIGUCCI JR., Davi. Humildade, paixão e morte: a poesia de Manuel Bandeira. São Paulo: Companhia das Letras, 1990.

ARTURO, Aurelio. "Rapsodia de Saulo". Morada al Sur. Bogotá: Universidad Externado de Colombia, 2004, p. 57-60. Disponível em <https://www.uexternado.edu.com/wp-content/uploads/2017/01/7-moradaAlSur-

AurelioArturo.pdf>.

BENJAMIN, Walter. "O narrador: considerações sobre a obra de Nikolai Leskov". In: Magia e técnica, arte e política: ensaios sobre literatura e história da cultura. Obras escolhidas v. 1. 7ª edição. Tradução de Sergio Paulo Rouanet; prefácio de Jeanne Marie Gagnebin. São Paulo: Brasiliense, 1994.

"Experiência e pobreza", Magia e técnica, arte e política. Obras escolhidas v. 1. $7^{\text {a }}$ edição.

Tradução de Sergio Paulo Rouanet; prefácio de Jeanne Marie Gagnebin. São Paulo: Brasiliense, 1994.

"Sobre Alguns Temas em Baudelaire". Charles Baudelaire: um lírico no auge do capitalismo.

Obras escolhidas v. 3. $1^{1}$ edição. Tradução de José Martins Barbosa, Hemerson Alves Baptista. São Paulo: Brasiliense, 1989.

"Paris do Segundo Império - o flâneur". Charles Baudelaire: um lírico no auge do capitalismo.

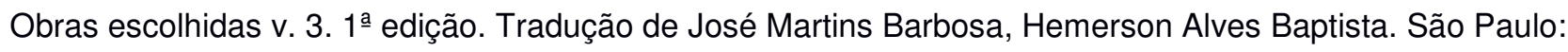
Brasiliense, 1989.

BERARDINELLI, Alfonso. "Quatro tipos de obscuridade". Da poesia à prosa. São Paulo: Cosac Naify, 2007 BOTELHO, André; BASTOS, Élide Rugai; VILLAS BOAS, Gláucia (orgs.). O moderno em questão: a década de 1950 no Brasil. Rio de Janeiro: Editora Topbooks, 2008.

CAMILO, Vagner. "O fazendeiro do ar e o legado da culpa", In: José Antonio Pasta Jr. e Jacqueline Penjon, Littérature et modernisation au Brésil. Paris: Presses Sorbonne Nouvelle, 2004 
CANDIDO, Antonio. "Literatura e cultura de 1900 a 1945". In: Literatura e Sociedade. São Paulo: Companhia Editora Nacional, $2^{\mathrm{a}}$ ed., 1967. . "“O escritor e o público". Literatura e sociedade. São Paulo: Companhia Editora Nacional, 2ª ed., 1967. "Literatura e subdesenvolvimento", A Educação pela Noite, 5르 ed. revista pelo autor, Rio de Janeiro: Ouro sobre Azul, 2006. "Prefácio". In: MICELI, Sérgio. Intelectuais à brasileira. São Paulo: Companhia das Letras, 2001.

FLORES JR., Wilson José. Ambivalências em Pasárgada: a poesia de Manuel Bandeira em suas tensões. Tese de doutorado, UFRJ/ FL, 2013.

GAGNEBIN, Jeanne Marie. "Walter Benjamin ou a história aberta". In BENJAMIN, Walter. Magia e técnica, arte e política. Obras escolhidas. $7^{a}$ edição. Tradução de Sergio Paulo Rouanet. São Paulo: Brasiliense, 1994.

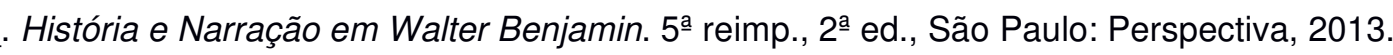
HOLANDA, Sérgio Buarque de. Raízes do Brasil. São Paulo: Companhia das Letras, 1999.

JESUS, Carolina Maria de. Quarto de Despejo. 9ae ed.,Rio de Janeiro: Francisco Alves, 1963.

LÖWY, Michael. Walter Benjamin: Aviso de incêndio - Uma leitura das teses "Sobre o conceito de história". São Paulo: Boitempo, 2005.

LÖWY, Michael e SAYRE, Robert. Revolta e melancolia: o romantismo na contracorrente da modernidade. Trad. Nair Fonseca, 1ํㅡㄹ ed. São Paulo: Boitempo Editorial, 2015.

MAMMì, Lorenzo. "João Gilberto e o Projeto Utópico da Bossa Nova”. Novos Estudos Cebrap, n.ำ 34, São Paulo, Cebrap, nov. 1992. . "Canção do Exílio". In: Três Canções de Tom Jobim. São Paulo: Cosac Naify, 2004.

MARQUES, Ivan Francisco. Cenas de um modernismo de província. Drummond e outros rapazes de Belo Horizonte. São Paulo: Ed. 34/FFLCH-USP, 2011. . "Herói fracassado: Mário de Andrade e a representação do intelectual no romance de 30", Teresa, no 16, 2015.

MICELI, Sergio. Intelectuais à brasileira. São Paulo: Companhia das Letras, 2001.

MORETTI, Franco. "O século sério", O Romance, vol. 1: A cultura do romance, Franco Moretti (org.), trad. Denise Bottman. São Paulo, Cosac Naify, 2009.

OLIVEIRA, Francisco de. Crítica à razão dualista/O Ornitorrinco. São Paulo: Boitempo, 2003.

ORTIZ, Renato Ortiz. A moderna tradição brasileira. São Paulo: Ed. Brasiliense, 1994.

PACHECO, Ana Paula. "Cidade-cárcere: violência e representação das classes baixas na literatura brasileira contemporânea", Terceira Margem, Rio de Janeiro, n.16, jan-jun/2007.

PASTA JR, José Antonio; PENJON, Jacqueline. Le rythme singulier d'une formation historique. Littérature et modernisation au Brésil. Paris: Presses Sorbonne Nouvelle, 2004.

PRADO JR., Caio. Formação do Brasil contemporâneo. São Paulo: Companhia das Letras, 2011. 
RIDENTI, Marcelo. "Intelectuais e romantismo revolucionário". São Paulo em Perspectiva, vol. 15 n. 2, São Paulo, abr-jun/2001.

ROSENFELD, A. "A teoria dos gêneros". In: O teatro épico. São Paulo: Perspectiva. 1965, p. 1-26.

SCHWARZ, Roberto. "Cultura e política 1964-69". O pai de família e outros estudos. São Paulo: Companhia das Letras, 2008.

Letras, 2008.

. "Sobre o Amanuense Belmiro". O pai de família e outros estudos. São Paulo: Companhia das

. "As ideias fora do lugar". In: Ao vencedor as batatas: forma literária e processo social nos

inícios do romance brasileiro. 6ª ed., São Paulo: Duas Cidades; Ed. 34, 2012.

. "Outra Capitu”. In: Duas Meninas. São Paulo: Companhia das Letras, 1997.

. "Conversa sobre Duas Meninas". Sequências brasileiras. São Paulo: Companhia das Letras,

1999.

. "Fim de século". Sequências brasileiras. São Paulo: Companhia das Letras, 1999.

. "Pelo prisma da arquitetura". Sequências brasileiras: ensaios. São Paulo: Companhia das

Letras, 1999.

. "Leituras em competição". Martinha versus Lucrécia. São Paulo: Companhia das Letras, 2012.

. "Um jovem arquiteto se explica", Martinha versus Lucrécia. São Paulo: Companhia das Letras,

2012.

. "Saudação a Sérgio Ferro". Martinha versus Lucrécia. São Paulo: Companhia das Letras,

2012.

"Agregados antigos e modernos", Martinha versus Lucrécia. São Paulo: Companhia das

Letras, 2012.

SOUZA, Gilda de Mello e. "Macedo, Alencar, Machado e as roupas". A ideia e o figurado. São Paulo: Duas Cidades; Ed. 34, 2005.

"A Estética rica e a Estética pobre dos professores franceses", Exercícios de Leitura. 2. a ed., São Paulo: Duas Cidades; Ed. 34, 2009.

WISNIK, José Miguel. Machado Maxixe: O Caso Pestana, São Paulo: Publifolha, 2008.

Jornais:

MENDONÇA, José Márcio. Adeus cronistas. Jornal da Tarde. São Paulo, 14 mar. 1972, p. 22-23.

Sites:

"CORTA-jaca" no Catete: centenário da alforria da música popular". Chiquinha Gonzaga. 2014. Disponível em: <chiquinhagonzaga.com/wp/corta-jaca-no-catete-centenario-da-alforria-da-musica-popular-brasileira/> . Acesso em 18 de fevereiro de 2018. 
